Working Papers No. 175/13

From Divergence to Convergence: Re-evaluating the History Behind China's Economic Boom

Loren Brandt, Debin Ma, and Thomas G. Rawski

(C) Loren Brandt, Debin Ma, and Thomas G. Rawski March 2013 
Department of Economic History London School of Economics Houghton Street London, WC2A 2AE

Tel: +44 (0) 2079557860

Fax: +44 (0) 2079557730 


\title{
From Divergence to Convergence: Re-evaluating the History Behind China's Economic Boom ${ }^{1}$
}

\author{
By Loren Brandt, Debin Ma, and Thomas G. Rawski
}

This version: Jan. 23, 2013

\begin{abstract}
China's long-term economic dynamics pose a formidable challenge to economic historians. The Qing Empire (1644-1911), the world's largest national economy before 1800, experienced a tripling of population during the $17^{\text {th }}$ and $18^{\text {th }}$ centuries with no signs of diminishing per capita income. While the timing remains in dispute, a vast gap emerged between newly rich industrial nations and China's lagging economy in the wake of the Industrial Revolution. Only with an unprecedented growth spurt beginning in the late 1970s did this great divergence separating China from the global leaders substantially diminish, allowing China to regain its former standing among the world's largest economies. This essay develops an integrated framework for understanding that entire history, including both the divergence and the recent convergent trend. We explain how deeply embedded political and economic institutions that contributed to a long process of extensive growth before 1800 subsequently prevented China from capturing the benefits associated with the Industrial Revolution. During the $20^{\text {th }}$ century, the gradual erosion of these historic constraints and of new obstacles erected by socialist planning eventually opened the door to China's current boom. Our analysis links China's recent development to important elements of its past, while using recent success to provide fresh perspectives on the critical obstacles undermining earlier modernization efforts, and their eventual removal.
\end{abstract}

\footnotetext{
${ }^{1}$ We have received valuable advice from many colleagues, including Masahiko Aoki, Timothy Brook, James Cassing, Nicolas Crafts, Wendy Dobson, Ronald A. Edwards, Phil Hoffman, Ralph Huenemann, Wolfgang Keller, Peter Lindert, LIU Pei, LI Bozhong, LONG Denggao, Deirdre McCloskey, Joel Mokyr, Andrew Nathan, Margaret Pearson, Kenneth Pomeranz, Evelyn Rawski, Tirthankar Roy, Roger Sahs, Carole Shiue, Richard Smethurst, Tuan-hwee Sng, Werner Troesken, Rubie Watson, Jeffrey Williamson, Bin Wong, Tim Wright, Jan Luiten van Zanden, Madeleine Zelin and participants in the May 2010 and September 2012 Asian Historical Economics Conferences. We would also like to thank Janet Currie and four anonymous referees for their very helpful suggestions. The usual disclaimer applies.

${ }^{2}$ Brandt, University of Toronto, brandt@chass.utoronto.ca; Ma, London School of Economics, d.ma1@|se.ac.uk; Rawski, University of Pittsburgh, tgrawski@pitt.edu.
} 


\section{INTRODUCTION ${ }^{3}$}

China's enormous boom, now well into its fourth decade, invites inquiry into the historical antecedents of an unprecedented surge of productivity and prosperity that has lifted hundreds of millions from dire poverty, pushed the People's Republic to the forefront of global manufacturing and trade, and unleashed sweeping transformations of employment, education, urbanization, consumption, inequality, ownership, and many other dimensions of economic life in the world's most populous nation.

Earlier growth spurts in Japan, Taiwan, and Korea encouraged efforts to probe the domestic origins of recent dynamism. ${ }^{4}$ China's unexpected rush toward higher incomes invites similar questions. What circumstances enabled the hesitant reforms of the late $1970 \mathrm{~s}^{5}$ which restored only a small fraction of the market arrangements stifled by socialist policies during the previous three decades, to launch the economy on a steep and durable growth path? How could several hundred million Chinese villagers escape from absolute poverty within 10-15 years following the onset of economic reform during the late 1970s with, if anything, declining external support as former collective institutions withered away? How did the number of socalled "township-village" (TVE) enterprises jump from 1.5 million to nearly 20 million, including many with substantial overseas sales, between 1978 and 1990 without encountering a shortage of capable managers and accountants? How did millions of firms conduct business, often on a large scale, without well-developed systems of commercial law or property rights?

While developments that arose from China's planned economy, including the expansion of human capital and the latent competition inherent in the relatively complete sets of manufacturing industries created in most of China's 31 provinces, surely contributed to reformera growth, this essay is written in the conviction that historical legacies rooted in the decades and centuries prior to the establishment of the People's Republic in 1949 continue to exert powerful influence upon the evolution of China's economy.

Prior to the industrial revolution, China led the world in economic size and in many dimensions of technology. Writing before the onset of China's current boom, earlier generations of scholars (Marion J. Levy 1953, Albert Feuerwerker 1958) attributed China's subsequent reversal of fortune to the prevalence of nepotism, corruption, and other elements of Chinese society that prevented a vibrant response to European expansion of the sort attained during Japan's Meiji era (1868-1912). Subsequent events have overtaken these views; some

\footnotetext{
${ }^{3}$ Names of authors working in North America and Europe and publishing in English are presented Western style (e.g. Debin Ma). Names of Chinese and Japanese authors based in Asia and writing primarily in Asian languages appear in the East Asian fashion, surname first, with the surname capitalized for clarity (e.g. WU Chengming).

${ }^{4}$ For Japan, see Thomas Smith $(1959,1988)$, Kazushi Ohkawa and Henry Rosovsky (1973), Kozo Yamamura (1997), and Akira Hayami, Osamu Saitō and Ronald Toby (2004); for Taiwan, see Limin Hsueh et al (2001); for Korea, see Dong-se Cha et al (1997).

${ }^{5}$ Studies of China's economy during the reform era include Carl Riskin (1987), Chris Bramall (2000), Gregory Chow (2002), Justin Lin, Fang Cai and Zhou Li (2003), Barry Naughton (2007), and Brandt and Rawski (2008).
} 
observers now promote the opposite approach, attributing Asian prosperity to the "Confucian values" formerly seen as obstructing economic dynamism. ${ }^{6}$

More recently, James Lee, LI Bozhong, Kenneth Pomeranz, R. Bin Wong and others identified as the "California school" have reshaped perspectives on the dynamism and development of the mid-Qing (1644-1911) economy. Pomeranz in particular sees little difference in economic structure or per capita income between the most commercialized regions of China and Europe prior to the British industrial revolution. With development in both regions constrained by limited land, Pomeranz attributes Britain's head start in industrialization to cheap coal and superior access through its colonies to land-intensive goods rather than to any advantage linked to political, legal, or other institutional factors (2000). These bold claims have kindled intense controversy, sparked efforts to expand empirical comparisons spanning Europe and Asia, and catapulted Chinese economic history from a narrow specialty to a central concern of global historical studies.7

The present review8 seeks to illuminate the historical antecedents of recent Chinese dynamism, to specify the constraints that hindered the realization of China's latent potential prior to the start of the recent growth spurt, and to track the gradual relaxation of these constraints during the course of the 20th century. Our analysis of China's current boom, as well as the modest advances of the late 19th and early 20th centuries, helps to clarify the nature and impact of earlier constraints. In this way, we believe that recent developments can deepen our insight into historical realities and vice-versa.

Several specific questions will help to unify much of what follows:

Why was China unable to capitalize on its early economic and technological leadership? Why did China become a laggard among major global economies by the 19th century, if not before?

Once the Industrial Revolution was well underway, a succession of countries in Europe, Asia and the Americas followed England's lead. Why was China slow to take advantage of economic opportunities linked to the dissemination of new technology?

How do we explain the timing and unique scale of China's post-1978 breakthrough?

The first of these questions is the most difficult. We are more optimistic about tackling the second and the third. We anticipate - and here we disagree with the California school that institutions will figure prominently in explaining both the long delay in the onset of rapid growth and the mechanisms underlying China's recent growth spurt.

\footnotetext{
${ }^{6}$ See Wei-ming Tu 1996. The economic success of China, Taiwan, Hong Kong, Singapore, and overseas Chinese communities despite continued reliance on personal ties (guanxi) and other cultural practices long seen as incompatible with modernization undercuts this approach. Retired Singapore leader LEE Kuan Yew and others now point to "Asian values" as bulwarks of growth, prosperity and technological progress.

${ }^{7}$ The breadth and intensity of the debate on the historical comparison of economic growth between China and the West is evident from the Economic History Net forum 'Rethinking $18^{\text {th }}$ Century China' http://eh.net/forums/ChinaSum.html and in a debate between Andre Gunder Frank and David Landes at http://www.worldhistorycenter.org/who/seminar/pastyears/frank-landes/Frank-Landes_01.htm ${ }^{8}$ Previous surveys include Albert Feuerwerker (1961, 1992), Frank H. H. King (1969) and Kent Deng (2000).
} 
We begin with a survey of the long-term evolution of China's economy. Since we regard institutions as a crucial but neglected factor that can contribute to understanding both the failures and the triumphs of China's economy during the past two centuries, we then turn to an analysis of China's modern history from the perspective of political economy. Starting with a summary of the more robust stylized facts of the imperial Chinese economy, we lay out a broad analytic framework for analyzing the political economy of China's pre-modern system that has links to China's post-1949 system both before and after the onset of the economic reform initiatives of the late 1970s. Finally, we briefly examine the growth spurt following China's post1978 reforms with an eye to continuities as well as departures from historic patterns.

\section{LONG-TERM EVOLUTION OF CHINA'S ECONOMY}

Map 1 indicates the territories controlled by the Ming and the far larger dominions of the Qing emperors.9 The territory of today's People's Republic of China (PRC) approximates that of the Qing, except for the border changes in what are labeled "Xinjiang, Mongolia and Manchuria." Major rivers - the natural arteries of pre-industrial commerce - flow from west to east. (See MAP 1)

China's economic history covers several millennia. Although certain features of the economic, political and social system span much longer periods, our survey highlights major elements during the period since the mid-14 $4^{\text {th }}$ century encompassing the Ming (1368-1644) and Qing (1644-1911) dynasties and the ensuing Republican period (1912-1949), which ended with the defeat and exile of the Nationalist government led by CHIANG Kai-shek (JIANG Jieshi) and the establishment of the People's Republic of China in 1949. Our objective is two-fold: to acquaint non-specialist readers with key features of China's pre-1800 economy, and to highlight broad areas of agreement among specialized researchers that can serve as building blocks for subsequent analysis and interpretation.

We preface discussion of fundamental features of the Ming-Qing economy with a brief discussion of the earlier Song era (960-1279), which is essential because specialists often view Ming-Qing history in light of the Song era, jumping over the short-lived Yuan or Mongol reign (1279-1368).

\subsection{Song as the Peak?}

The Song (960-1279) and its Tang (618-907) precursor brought sweeping change to China's economy and society. Major new developments include the formation of institutions and structures that evolved into foundations of what historians see as "traditional" or "premodern" China: consolidation of political control in the emperor's hands; a tax system based on

\footnotetext{
${ }^{9}$ Although the map locates Taiwan outside the Qing borders, the Qing exercised effective control over the island between 1683 and 1895, when it passed into the hands of Japan.
} 
registration and assessment of privately-held land; a merit-based civil service staffed by commoners rather than aristocrats; and the use of written examinations to select candidates for official appointments, accompanied by a shift to an agricultural regime based on small-holder ownership and tenancy, the expansion of markets for commodities and factors, the penetration of money in commercial exchange, and the extensive development of private commerce. ${ }^{10}$

The late Joseph Needham's massive volumes on Science and Civilization in China [summarized in Needham and Colin Ronan 1978] document the extraordinary spurt of TangSong innovation, including breakthroughs in gunpowder, the magnetic compass, movable type, paper, and shipbuilding, improvements that commanded world-wide admiration:

Printing, gunpowder and the compass: These three have changed the face and state of things throughout the world; first in literature, the second in warfare, the third in navigation; whence have followed innumerable changes, in so much that no empire, no sect, no star seems to have exerted greater power and influence in human affairs than these mechanical discoveries" (Francis Bacon, New Instrument, 1620).

Needham's works establish China as the global leader in many fields of scientific and technological endeavor until perhaps the $14^{\text {th }}$ century. Why this advantage did not lead to an industrial revolution is known as the "Needham puzzle" (Justin Yifu Lin 1995; Kent Deng 2003).

Deep institutional change and technological progress (which may be linked - see Francesca Bray (1994)) had major qualitative impact on the Song economy. Some scholars, notably Eric Jones (1988), go further, depicting the Southern Song (1127-1289), as an early and remarkable episode of "intensive" growth - meaning increases in urbanization, marketed agricultural surplus, and the level of per capita income - that subsequent dynasties failed to replicate. G.W. Skinner concludes that "levels of urbanization achieved in the most advanced regions were higher in the medieval [i.e. Song] era than in late imperial times" (1977b, p. 28).

Angus Maddison's estimates of global economic aggregates, summarized in Table 1, reflect this "Song peak" thesis, indicating a considerable rise in China's absolute and relative per capita GDP between the late tenth century and 1300, followed by six centuries of stagnation or decline in both indicators. (See TABLE 1)

While the Song peak perspective continues to receive scholarly support, most recently from QI Xia (1999, 2009) and William Guanglin Liu (2005), the quantitative underpinning of key elements remains controversial. Donald Wagner describes Robert Hartwell's widely cited high estimate of Song iron production (1962) as a "guess," arguing that "no reliable calculation is possible on the basis of presently available sources" (2008, p. 300; 2001, p. 176). While Pingti Ho (1956) and SUDŌ Yoshiyuki (1962) documented the spread of new rice seeds, expanded irrigation and other agricultural improvements during the Song era, critics question whether these innovations cumulated to major agricultural change in the aggregate (as opposed to localized improvements clustered in the Lower Yangzi region), arguing that available documents

\footnotetext{
${ }^{10}$ Modern scholarship in this area begins with the so-called NAITO thesis by the pre-war Japanese scholars like NAITO Kōnan, see a summary of his thesis in Hisayuki Miyakawa 1955. Richard von Glahn's review of recent monetary studies (2004) cites an array of relevant work by Chinese, Japanese, and western researchers.
} 
do not give a clear picture of the extent of irrigated rice cultivation, the level of crop yields, or the size of the agricultural surplus (LI Bozhong 2002, chaps. 5 and 6; ŌSAWA Masaaki 1996, esp. pp. 236-240).

\subsection{Major Features of China's Ming-Qing Economy}

Demography is integral to any narrative of China's long-term economic evolution. There are three crucial dimensions: the size of China's population at specific dates; its rate of growth; and the underlying demographic regime, typically described in terms of total marital fertility, mortality, and nuptiality. Estimates of the size and growth of China's population begin with censuses conducted by each dynasty/regime, while interpretations of demographic behavior build on family genealogies and other micro-level data. ${ }^{11}$

Careful empirical study of China's historical demography begins with the work of Ping-ti Ho (1959), who examined the institutional dimensions of census-taking during the Ming (13681644) and Qing (1644-1911) dynasties. The 1953 population census, the first conducted by the People's Republic of China (PRC), and probably the most accurate to that point, provides an important milepost that helps to triangulate earlier estimates.

Concerns over the reliability of Ming and Qing census figures arise from their reliance on self-reporting, the incentive for misreporting inherent in the use of population (and land) registers to assign tax obligations, and the incompleteness of reporting systems, particularly in regions populated by ethnic minorities. A Ming ditty captures some of these sentiments: ${ }^{12}$

Barren soil along the river, the harvest not yet ready

New taxes are announced, and yet another levy,

Every household subdivides, trying to evade them-

And officials mistake the whole thing for a growth in population!

Ping-ti Ho emphasizes the comprehensiveness and broad accuracy of early Ming population registration (circa 1400), but finds the remaining estimates for the Ming untenable. In his view, it is not until the mid-Qing, (ca. 1790s), and then only until the Taiping rebellion (1851-1864), that we can place substantial confidence in the official reporting system (1959, p.

\footnotetext{
${ }^{11}$ The most important sources of micro-demographic data are for the Qing imperial family and for Banner settlements (a legacy of Manchu military organization) residing in present-day Liaoning province. Both groups are dominated by ethnic minorities whose demographic behavior might differ from that of the majority Han population. Liaoning's abnormally high land/labor ratio could also have influenced demographic outcomes.

${ }^{12}$ Lanyang xianzhi [Lanyang county gazetteer, 1545], with thanks to Timothy Brook.
} 
270) and the population totals that it generated. ${ }^{13}$ Coming between the relatively firm totals for 1400 (70 million) and 1794 (310 million), the invasion from China's northeast (Manchuria) that ousted the Ming and established Qing rule (ca. 1644) resulted in significant, but unquantifiable population loss that could have amounted to many millions.

Problems multiply at the regional level. ${ }^{14} \mathrm{G}$. William Skinner (1987) reconstructed the arbitrary adjustments that provincial officials used to update early $19^{\text {th }}$ century population reports in Sichuan province, raising concerns about other $19^{\text {th }}$ century estimates. Skinner's revisions, (along with earlier work by Dwight Perkins (1969)), suggest a population of no more than 390 million on the eve of the Taiping Rebellion (1851-1864), or at least 40 million lower than the official figures. This revision has important implications not only for our view of $18^{\text {th }}$ and $19^{\text {th }}$ century population growth, but, in light of losses from the Taiping Rebellion that earlier estimates placed in excess of 60 million, for the early $20^{\text {th }}$ century as well..$^{15}$

Despite these uncertainties, there is a core of solid information. Over a period spanning a half a millennium, China's population grew from approximately 70 million in 1400 to approximately 400 million in 1850 and 500 million around 1930, implying annual growth averaging approximately 0.4 percent per annum. Rates of growth were lower or negative during periods of succession, rebellion or famine, and higher in interludes of recovery and, in all likelihood, during the $16^{\text {th }}$ and $18^{\text {th }}$ centuries, which qualitative accounts identify as periods of stability and commercial expansion. Within this framework, we also recognize substantial heterogeneity across regions and time periods, particularly during episodes of large-scale migration. Complex interactions between economic, social and political forces shaped demographic behavior, possibly, as G. William Skinner's (1977a, b) work anticipates, in ways that differed across regions. Despite recent contributions, scholars are unable to reconstruct the household behavior patterns that drove the trajectory of China's enormous demographic aggregate.

Massive population growth with stable long-run living standards is the defining feature of the Ming-Qing economy. Output kept pace with population: despite fluctuations and regional variation, we see no downward trend in per capita consumption. In the absence of widespread technical change, growth, which clustered on the extensive margin, is described as "Smithian" (e.g. by R. Bin Wong 1997) because of its dependence on increasing specialization and division of labor.

\footnotetext{
${ }^{13}$ Official records, for example, show impossibly large increases of one-third between 1760 and 1775 and one-half between 1760 and 1790, perhaps because the Qianlong emperor demanded that officials "ascertain the true population of the empire" after a 1775 regional crop failure exposed the failings of previous tallies (Ho 1959, pp. 47, 281).

${ }^{14} \mathrm{Ge}$ Jianxiaong et al, Zhongguo renkoushi [History of China's Population], a multi-volume study by historical demographers at Fudan University, offers important new results that develop aggregate totals from meticulously researched regional or county figures.

${ }^{15}$ Skinner's downward revision to the 1850 population figures raises the possibility that estimates of the loss of life may be too high. Independently, Peter Schran argues for a speedy recovery of population in the aftermath of this shock. He finds the notion of "substantial decline" in China's population between 1850 and 1873 to be "quite implausible" and concludes that "losses due to the Taiping and Nien rebellions had almost been made up" by 1873 (1978, pp. 645-646). CAO Shuji (2001), however, argues for high mortality during the Taiping Rebellion.
} 
Dwight H. Perkins' (1969) analysis of agriculture, which dominated the economy and occupied a majority of the labor force, provides the strongest empirical support for this perspective. The agricultural economy consisted of millions of small family farms, with average farm size by the $18^{\text {th }}$ century less than 5 acres. ${ }^{16}$ Focusing on grain production, which occupied over 80 percent of total acreage, Perkins attributes long-term Ming-Qing output growth in roughly equal amounts to expanded acreage and higher yields, i.e. the extensive and intensive margins. Between 1400 and 1913, Perkins estimates that cultivated land more than tripled, rising from 370 to 1,360 million mou, while population increased more rapidly, more than quintupling from 65-80 million in 1400 to 430 million in $1913 .{ }^{17}$

Improved yields, among the world's highest at that time, in turn, arose from growing intensification of tillage enabled by an increased supply of labor and fertilizer per unit of land along with improved seeds and implements. This dynamic reflects the views of Ester Boserup (1965) in that population growth drives economic expansion by opening the door to increased cultivation of labor-intensive crops and greater use of multiple cropping and other labor-using methods. While known techniques spread across China's landscape, Perkins finds little evidence of technical change in Ming-Qing agriculture aside from the importation of new food crops (maize, Irish and sweet potatoes).

Subsequent regional studies, many directed toward the prosperous, highly commercialized Lower Yangzi area near present-day Shanghai, enlarge Perkins' picture of an economy that responds to gradually rising population density by adding new layers of specialization and division of labor that preserve living standards in the face of a rising man-land ratio.

\subsubsection{Commercialization, domestic trade, market integration}

The capacity of the Ming-Qing system to ward off diminishing returns rested on progressive intensification of agricultural rhythms, growing household and regional specialization, expanded transport systems and deepening markets for commodities as well as the land and labor that produced them. Exploiting uniquely rich documentation available for Jiangnan (referring to the southern portion of Jiangsu province, which occupies the heart of the Yangzi delta), LI Bozhong $(2000,2010 a)$ reviews the emergence and growth of specialized production in textiles, food processing, apparel, tobacco, papermaking, printing, toolmaking, construction and shipbuilding during 1550-1850.

Building on the considerable growth of markets and commerce recorded under the Song (960-1279), some of which eroded during the Mongol (Yuan) interregnum (1279-1368), the

\footnotetext{
${ }^{16}$ Farm size was smaller in the south, reflecting the a warmer climate, longer growing season, greater availability of water, and higher multiple cropping ratios. Land rental was also more common in the south, with estimates suggesting that tenants cultivated over one-third of farmland (John L. Buck 1930, 1937)

${ }^{17}$ Perkins $(1969$, p. 16). Perkins notes substantial regional variation in the of expansion of cultivated area and population (p. 18ff). One hectare is equivalent to $15 \mathrm{mou}$ (p. 16).

${ }^{17}$ Perkins (1969, p. 16). Perkins notes substantial regional variation in the of expansion of cultivated area and population (p. 18ff). One hectare is equivalent to $15 \mathrm{mou}$ (p. 16).
} 
Ming-Qing era witnessed renewed development of trade and growing agricultural commercialization. Perkins concludes that "shipments of agricultural products out of rural areas to domestic and foreign markets. . . probably amounted to. . . under 7-8 per cent of farm output" before the $20^{\text {th }}$ century $(1969,119)$. Perkins estimates that $30-40$ percent of agricultural products were marketed during the early $20^{\text {th }}$ century $(1969,114)$. The implied breakdown between local and long-distance trade, with roughly one-fourth of marketed farm products entering long-distance trade, may approximate circumstances of earlier periods.

Early Ming renovation of the Grand Canal facilitated the northward shipment of tribute grain to the capital, providing a new channel for north-south trade. ${ }^{18}$ The sea route from the Lower Yangzi northward around the Shandong peninsula to Tianjin, "virtually abandoned" under the Ming, was revived during the Qing period and extended northward to connect with commodity flows along the Liao River in Manchuria (XU Dixin and WU Chengming eds., 2000, p. 166). The growth of what became the large middle-Yangzi river port of Hankou (now known as Wuhan) from "a desolate sandbank" during the Ming era to the "hub of a trade network linking Sichuan and Shaanxi [provinces] to central and south-eastern China" by 1813 reflects "the development of trade along the Yangzi" River during the Qing era (XU and WU 2000, p. 165; William T. Rowe, 1984).

Multiple studies trace the Qing deepening of domestic commercial networks (e.g. Evelyn Rawski 1972, Gilbert Rozman 1974), which influential work by G.W. Skinner (1964) showed to consist of nested hierarchies of marketplaces, differentiated according to the periodicity of market sessions, the scale of activity and the array of products and services transacted, that extended from the largest cities to remote villages. Increases in the number of towns and markets were particularly evident in the densely populated delta regions surrounding modernday Shanghai and Guangzhou (WU Chengming 2002, p. 186).

The analysis of Qing price data for food grains, which local governments reported upward on a monthly basis, reveals substantial price integration, most notably across localities linked by low-cost water transport (Ch'üan and Kraus 1975). Yeh-chien Wang concludes that "early eighteenth-century China was, on the whole, comparable with Europe in terms of market integration" (1992, p. 53); Carol Shiue and Wolfgang Keller (2007) confirm this, and show that the Lower Yangzi area achieved greater price integration than continental Europe (but not England). ${ }^{19}$

\footnotetext{
${ }^{18}$ The Grand Canal was initially constructed during the Sui Dynasty (AD 589-616) and became a main inland artery that helped to forge the unification of the subsequent Tang and Song empires (CH'ÜAN Han-sheng, 1990).

${ }_{19}$ Qing records present grain quantities and silver values in standard units. In reality, currencies, weights and measures varied substantially across regions and occupations (e.g. Frank H.H. King 1965 on currency variation). The absence of information about the conversion of local market transactions into standard units adds an element of uncertainty to these studies.
} 


\subsubsection{Finance and Credit}

Ming-Qing networks of markets and trade drew support from both formalized and informal finance. The formal system was organized around traditional or "native" banks (qianzhuang) that were largely local in nature, but maintained links beyond their home regions. This system included a nationwide network (the "Shanxi banks," whose name signified their roots in Shanxi province) that specialized in managing official funds and arranging long-distance transfers (Andrea McElderry 1976, Randall Morck and Fan Yang 2011). These institutions, whose owners faced unlimited liability, accepted deposits, issued loans, arranged interregional (and in some cases, overseas) remittances, and sometimes originated bank notes (typically restricted to local circulation). These financial networks commanded respect from outsiders: Chinese bankers financed much of the mid-19 ${ }^{\text {th }}$ century trade with Europeans; an 1890 Japanese consular report lamented the competitive weakness of Japanese merchants, and concluded the "The dominance of Chinese merchants is ultimately attributable to. . . their superior financial network" (HAMASHITA Takeshi 2008, p 174).

Local "money shops" conducted currency exchange (between copper and silver, between notes and hard currency, and among local and trade-specific bookkeeping currencies) as well as currency valuation (i.e. verifying the fineness of un-coined silver or valuing strings of copper cash that included counterfeit or "clipped" coins). Pawnshops issued small loans against a variety of collateral; ABE Takeo places the number of rural pawnshops at 19,000 in the mid- $18^{\text {th }}$ century and 25,000 by the early 1800 s, indicating an average of approximately 10 establishments for each of China's counties (Zelin 1991, p. 44).

Beyond these formal organization stood a vast array of informal arrangements. Shopkeepers, tradesmen, and individuals served as regular sources of personal loans; relatives and friends provided funds on a more casual basis. Transactions ostensibly involving the exchange of land or labor often included elements of lending or borrowing (Loren Brandt and Arthur Hosios, 1996). Given the irregular timing of farm income, this tapestry of credit options enabled farmers to monetize land use rights associated with both tenancy and ownership, offering substantial protection against sudden downward mobility following illness, death or harvest failure. Such arrangements surely enhanced social stability.

While these mechanisms facilitated exchange, high interest rates and substantial transaction costs limited potential benefits. Legal restrictions did not shield Chinese households from high borrowing costs. ${ }^{20}$ Ramon Myers' study of two north China provinces, Hebei and Shandong, found typically monthly interest rates of 3 percent in the late $18^{\text {th }}$ and early $19^{\text {th }}$ century, and 2-4 percent during the 1930s. (1970, p. 243). Philip Huang's review of information from the 1930s shows that rural households in north China borrowed at monthly rates between 1.2 and 3 percent, "with most loans made at 2 percent" per month (1985, p. 189). Rural households that owned land could obtain credit at substantially lower rates by ceding "use rights" to land in return for a loan. Once the loan was repaid, the use rights were returned. Land mortgage (diandi)

\footnotetext{
${ }^{20}$ Successive dynasties enacted (but rarely enforced) statutory limits on annual interest, which were 36 percent under the Ming, and 20 percent during Qing and the Republic (Zhiwu Chen, Kaixiang Peng and Weiping Yuan 2010).
} 
contracts from northeast China for the 1930s indicate implicit annual rates in the neighborhood of ten percent.

Lending rates differed substantially across regions, reflecting the often highly local nature of these markets. Surveys conducted during the 1930s showed modal values for annual interest costs on unsecured personal loans ranged from 20-30 percent in coastal regions like Guangdong, Fujian, and Zhejiang to higher figures approaching and sometimes exceeding 50 percent in poorer and less commercialized provinces like Henan, Jilin, Suiyuan, and Ningxia (Loren Brandt and Arthur Hosios, 2009; PENG Kaixiang et al 2009).

A compilation tabulating three centuries of rural interest rates nationwide reveals no sign of the gradual decline observed in Western Europe. ${ }^{21}$ Myers finds that borrowing costs for rural households remained "quite constant over a period of two hundred years" ending in the 1930s (1970, p. 243). Possible explanations for high Chinese rates and limited development of financial institutions and markets comparable to those in early modern Western Europe will be addressed later.

\subsubsection{Urbanization}

This well-developed market network supported increasingly dense population settlements, particularly in prosperous, trade-oriented regions. Authors like Gilbert Rozman (1974), G. William Skinner (1977ab) and CHAO Shuji (2001, p. 829), who assign the label "urban" to settlements exceeding a fixed number of residents, derive average rates of national urbanization ranging from 3 to over $7 \%$, fairly low by the standards of early modern Europe. This leads scholars such as Kang Chao (1986) to attribute the overall slow growth of cities to a low and declining agricultural surplus.

Rather than large urban centers, the lower Yangzi region developed a distinctive pattern of urban settlements, forming clusters of market towns along the dense regional network of rivers, creeks, and man-made canals, with extensive geographic specialization in the marketing and production of agricultural and handicraft products (LIU Shijie 1987). The resulting economic geography, with no clear boundaries between urban and rural districts or farming and non-agricultural activity, defeats standard measures of urbanisation. LI Bozhong argues that standard classification schemes may underestimate the degree of urbanization in the lower Yangzi region, which he places at 20 percent during mid-Qing $(2000,414)$. But these estimates, derived from non-standard definitions, lack international comparability.

\footnotetext{
${ }^{21}$ See PENG Kaixiang et al 2009; for China, For Western Europe, see Donald McCloskey and John Nash 1984; Sidney Homer and Richard Sylla 2005.
} 


\subsubsection{International exchange before 1800}

Although the bulk of demand and sales involved purely domestic transactions, there was a small but significant international trade. Largely confined to China's coastal and border regions, and periodically restricted by the state, most of this trade was intra-Asian, with China shipping manufactures (porcelain, silk) by sea to Southeast Asia and tea overland to Central Asia, while importing timber, spices, and monetary metals by sea and horses from Central Asia. $^{22}$

European explorers arriving in Asian waters during the early $16^{\text {th }}$ century encountered well-established networks of water-borne trade connecting Chinese merchants and vessels with the rest of Asia (Andre Gunder Frank 1998). Trade with Europe rose, both directly and through the integration of European merchants into Asian trade networks. China's silk, ceramics and tea found new markets in Europe's expanding cities (Jan de Vries, 2008; Timothy Brook, 2010). Chinese sought European luxuries (window glass, clocks), metals and fabrics (Frank Dikötter 2006, p. 28).

Aside from the effect of silver inflows, which exerted major influence on China's monetary system from the $16^{\text {th }}$ century onward, the impact of international trade on Chinese prices, incomes, organization and production remained small prior to 1800; these commodity flows may have exerted greater domestic impact on China's trade partners. Sketchy data suggest one percent of GDP as a generous upper bound to China's trade ratio (imports plus exports divided by GDP). ${ }^{23}$ Scattered evidence also indicates that overseas shipments absorbed only modest shares of output from the main export industries. ${ }^{24}$

China's persistent merchandise trade surplus financed massive imports of New World silver. Silver imports reflected huge pre-trade differences in the gold price of silver between China and the rest of the world (Dennis O. Flynn and Arturo Giraldez, 1994) as well as Chinese growth and commercialization described above. China had limited deposits of precious metals and, after repeated misadventures with paper currency during the early Ming period (Richard von Glahn 1996), a decided preference for hard money. Von Glahn (2003) estimates that China's $18^{\text {th }}$ century silver imports may have exceeded one billion taels, representing an annual inflow equal to roughly 0.25 percent of GDP. ${ }^{25}$ By 1640, these flows had eliminated major

\footnotetext{
${ }^{22}$ Gang Deng provides a detailed account (1997, Chap. 5).

${ }^{23}$ China's Maritime Customs trade data begin in the 1850s; the first comprehensive national income estimates are for 1933 (Ta-chung Liu and Kung-chia Yeh, 1965). Together, they suggest a trade ratio of 8-10\% of GDP prior to the 1930s Depression. Backward projection based on these trade data and reasonable assumptions for GDP growth puts this ratio at no more than 2 percent in 1870 . Since trade surely outpaced output growth during the $19^{\text {th }}$ century, we propose one percent of GDP as a generous upper bound for China's pre-1800 trade ratio.

${ }_{24}$ Robert Gardella reports calculations by WU Chengming indicating that tea exports amounted to 23 percent of total output in $1840(1994$, p. 6). Tea exports carried by the East India Company doubled between 1786 and 1830, while export of Fujian tea to Russia increased by a factor of six between 1798 and 1845 (ibid., 37-39) indicating far smaller $18^{\text {th }}$ century export shares. Evidence for silk points in the same direction. In 1880, exports of raw and woven silk amounted to 1.17 million piculs or 55 percent of total output (Lillian M. Li 1981, p. 100). For the $18^{\text {th }}$ century, scattered figures imply that exports were a tiny fraction of the 1880 total: Li cites sources reporting that Japan imported 3,000 piculs of Chinese silk "in an exceptionally good year" and that annual shipments to Mexico, another major outlet, may have totaled 10,000 piculs (ibid. 64-65). A picul is a measure of weight equivalent to $60.489 \mathrm{~kg}$.

${ }^{25}$ Our crude calculations for the late $18^{\text {th }}$ century assume a population of 385 million (Perkins 1969, p. 16) ; annual per capita grain consumption of 3 shi; an average grain price of 2 taels per shi; a
} 
cross-national differences in the gold price of silver; thereafter, "silver continued to gravitate to the Chinese market. . . because there was a huge number of buyers at a relatively stable world price" (Flynn and Giraldez 1995, p. 433). Significant price differentials persisted, however, with respect to other important agricultural and non-agricultural commodities.

\subsubsection{Households, human capital, and private organizations}

The concept of "homo economicus," invented by thinkers with little knowledge of Asia, fits the historical realities of Chinese village life. Anticipating the Wealth of Nations by two millennia, Han Fei-tzu (ca. 280-233 BC) mirrors Smith's vision of individual behavior:

in the case of workmen selling their services in sowing seeds and tilling farms, the master would. . . give them delicious food and by appropriating cash and cloth make payments for their services. Not that they love the hired workmen, but that. . . by so doing they can make the workmen till the land deeper and pick the weed more carefully. The hired workmen. . . speedily pick the weed and till the land .... . Not that they love their master, but that. . . by their so doing the soup will be delicious and both cash and cloth will be paid to them. Thus, the master's provisions and the workmen's services supplement each other as if between them there were the compassion of father and son. However. . . they cherish self-seeking motives (Han Fei-tzu, n.d.).

Studies of North China's rural economy by Myers (1970) and Philip Huang (1985), of Fujian and Hunan by Evelyn Rawski (1972), and of the Lower Yangzi region by Huang (1990) and LI Bozhong (1998, 2000, 2010a), among others, depict a diligent, ambitious, marketoriented peasantry that responded aggressively to opportunities for economic gain. Villagers were deeply engaged with markets: in the more commercialized coastal and riverine districts, many households made daily trips to local markets (Madeleine Zelin 1991, p. 38). Ambitious individuals could enter the world of commerce as brokers or go-betweens with no prior accumulation of wealth. In the absence of official restrictions on personal mobility, peddlers and merchants were free to move to promising locations; numerous huiguan, local organizations of merchants from distant places, attest to the importance of commercial sojourning (HE Bingdi 1966).

The practical environment of village life placed a premium on literacy and numeracy, both of which reached substantial levels. Historical links between education and social mobility reinforced this tendency, as did popular culture. Evelyn Rawski (1979) shows that strong household demand for education, coupled with low prices for teaching services and for books, produced levels of literacy in Qing China that outstripped much of preindustrial Europe. Work on age-heaping (the tendency for uneducated people to give their ages in round numbers) also suggests levels of numeracy in the Chinese population of the $19-20^{\text {th }}$ centuries much higher than countries with comparable or even slightly higher level of development (Joerg Baten et al 2010). Widespread use of book-keeping and accounting by households, business, lineage 
trusts and guilds confirms the high level of commercial orientation and numeracy (Robert Gardella 1992, Weiping Yuan and Debin Ma 2010).

Official interactions with the rural populace, including the collection of land taxes and the registration system intended to promote public security, routinely used written materials. A substantial publishing industry churned out agricultural manuals as well as cheap editions of popular novels (Cynthia Brokaw and Kai-wing Chow 2005). As quantifications of printed editions of book per capita show, Western Europe and East Asia were the only regions of the world in the early modern era that had mass printing (Jan Luiten van Zanden 2009, chapter 6).

Chinese villagers deployed their knowledge of reading and arithmetic to economic ends. There was a brisk market for cheap books containing "sample contract[s]. . forms for selling and mortgaging lands, houses, or livestock; tenancy contracts; [and] loan agreements" (Evelyn Rawski 1979, p. 114); agricultural handbooks discussed household allocation choices in language reminiscent of modern price theory texts (Evelyn Rawski 1972, pp. 54-55).

Summarizing work by Myron Cohen and others, Zelin observes that "Even in remote [Qing] villages. . . written contracts were used in the hiring of labor, sale and rental of property, distribution of land-use rights, marriage and concubinage, and the sale and indenture of human beings" (1994, p. 40).

Another striking feature of Qing rural society is the capacity of both elites and ordinary villagers to construct and manage complex organizations, and to adapt them to changing circumstances in the pursuit of economic objectives. In addition to kinship groups, some of which controlled substantial wealth, village-level groups included associations for cropwatching, defense, and maintenance of temples and irrigation works, along with "revolving credit associations . . . . [and] associations. . . to build bridges and schools, endow ferries, and repair roads" (Zelin 1991, pp. 40-41). Living in a society thickly populated with organizations familiarized villagers with the processes of designing and implementing rules, managing organizational affairs and assets, and manipulating operations to tilt outcomes in personally advantageous directions.

Beyond the village, informal networks and private organizations facilitated China's long history of markets and commerce. Chinese guilds united people who shared lineage or nativeplace ties as well as common occupations. ${ }^{26}$ Fu-mei Chen and Myers $(1978,1989 / 1996)$ and Zelin (1994) show how mercantile associations and customary law encouraged stable and reliable commercial practices. With clear parallels to Avner Greif's $(2006,2008)$ work on Europe, Jean-Laurent Rosenthal and R. Bin Wong emphasize the contribution of informal arrangements to supporting long-distance commerce: when trade partners reside far apart, high costs of transport and communication prevent official courts from efficiently resolving disputes. Under these conditions, informal arrangements appear "not to palliate failed formal institutions but as complements that enables market exchange" (2011, p. 236).

Comparisons across time and space highlight the coherence and potential of this organizational repertoire. T. Rawski (2011a) and others have remarked that China's post-1978 boom drew heavily on an informal revival of traditional commercial mechanisms that several

\footnotetext{
${ }^{26}$ Work on guilds includes John Burgess 1928/1966; Hosea B. Morse 1909, NEGISHI Tadashi 1951, William T. Rowe 1992, and Christine Moll-Murata 2008.
} 
decades of Communist regulation and propaganda had endeavored to suppress. The economic success of Chinese migrants offers further evidence. $19^{\text {th }}$ century migrants to Thailand, many of whom "came. . . almost straight from the farm," quickly came to dominate Thailand's domestic and international commerce. In contrast to Thai natives, G. William Skinner comments that Chinese migrants hailed from "a grimly Malthusian setting where thrift and industry were essential for survival." Ideology reinforced this divergence: Chinese struggled for wealth to preserve family and lineage continuity, while Thai norms frowned on "excessive concern for ... . material advancement." Differences in proverbs tell the story: for the Chinese, "Money can do all things," but for the Thai, "Do not long for more than your own share" (1957, pp. 97, 92, 93, 95).

A century later, Chinese migrants display similar capabilities in Italian city of Prato:

Chinese laborers, first a few immigrants, then tens of thousands. . . transformed the textile hub into a low-end garment manufacturing capital — enriching many, stoking resentment and prompting recent crackdowns. ... [A local industrialist commented that] The Chinese are very clever. They're not like other immigrants. . . . [Reporters noted that] what seems to gall some Italians most is that the Chinese are beating them at their own game - tax evasion and brilliant ways of navigating Italy's notoriously complex bureaucracy - and have created a thriving, if largely underground, new sector while many Prato businesses have gone under (Rachel Donadio 2010).

\subsubsection{Summary of pre-1800 Ming-Qing economic evolution}

That the economy of Ming-Qing China, governed by a tiny cadre of officials wielding small and declining fiscal resources (discussed below), delivered food, clothing and shelter to an immense and growing population despite growing demographic pressure and without widespread technological change surely merits recognition among the economic wonders of the pre-modern world.

While the claims of "Song peak" proponents continue to attract controversy, recent studies on both Ming (e.g. Timothy Brook 1999, 2010) and Qing (e.g. XU and WU 2000; LI Bozhong 2000, 2003) view China's long-term achievements as resulting from centuries of gradual development that cumulated to substantial gains in crop yields, specialization, commercialization, monetization, trade volumes and other dimensions of pre-1800 economic life.

Similar revisionist views apply to long-term demography. Current texts (Bruce A. Elleman and S.C.M. Paine 2010, pp. 105) echo long-standing assertions about excessive population pressure dating back to Thomas Malthus and reflected in the research of Huang $(1985,1990)$ and Kang Chao (1986). California School authors, by contrast, insist that "the conventional contrast of population dynamics in late imperial China and early modern Europe is no longer persuasive" (William Lavely and R. Bin Wong 1998, p. 741). James Z. Lee and Feng Wang (1999) argue that China's unusual combination of near-universal female marriage and relatively 
low birth rates reflects the widespread incidence of female infanticide, primitive contraception and abortions, intentional spacing of births, and adoptions. ${ }^{27}$

These perspectives echo the rise of "industrious revolution" a label used to describe the trajectory of pre-industrial Holland, England or even Tokugawa Japan. It downplays structural breaks separating the "pre-industrial" era from the "Industrial Revolution," highlighting instead the long period of slow cumulative change that preceded the industrial surge that began in the late $18^{\text {th }}$ century. Unlike England or Holland, however, China's economic development was largely self-contained, the sole (and important) exception being the large silver inflows that lubricated domestic commerce as well as public finance. Debate continues, with the California school claiming that the Qing Lower Yangzi region may have attained standards of living comparable to those in North-western Europe through the end of the $18^{\text {th }}$ century, whereas recent work by Allen et al (2011) and Li and van Zanden (2012) based on the purchasing power parity comparison of $19^{\text {th }}$-century incomes between the Lower Yangzi region and Holland uphold the more traditional finding that average Chinese per capita income during this period remained far below the level attained in England and the Netherlands.

\subsection{The Great Divergence}

Whether the great divergence between west European and Chinese levels of per capita income occurred in the $14^{\text {th }}$ or the $18^{\text {th }}$ century, the problem of explaining China's long economic decline relative to the industrializing West and then to Japan during the $19^{\text {th }}$ and early $20^{\text {th }}$ centuries, and subsequently to a number of dynamic East Asian economies during the third quarter of the $20^{\text {th }}$ century, remains unresolved. Different authors point to a variety of causal mechanisms.

Kenneth Pomeranz' widely cited study (2000) argues that leading regions in both China and Europe faced binding land constraints, and attributes England's rise to global economic leadership to two specific factors: cheap coal and access to land-intensive products from its colonies and Eastern Europe.

An earlier generation of scholars attributes China's relative economic decline to a general drop-off in innovative activity under the Ming and Qing. These researchers offer an array of economic and political explanations focusing on forces influencing the demand and supply for new technologies and innovation, the key source of intensive growth.

On the demand side, long-standing (but now contested, as noted above) Malthusian perspectives link population growth to a declining wage-rental ratio, which, in turn, promoted

\footnotetext{
${ }^{27}$ This field continues to evolve. Critics question both the data used by Lee and Wang and their conclusion that Chinese women had lower fertility than in other pre-modern societies (see the summary in Matthew H. Sommer 2010, pp. 101-103). Departing from an earlier consensus (James Nakamura and Matao Miyamoto 1982) that viewed China's population as subject to Malthusian positive checks in contrast to Tokugawa Japan's "precocious" demographic transition, SAITŌ Osamu (2002) notes the presence of preventive checks and low birth rates across East Asia, despite contrasting family and mobility patterns.
} 
the adoption of labor-using technology and labor-absorbing institutions that effectively crowded out labor-saving and capital-using technical changes that might have promoted higher labor productivity and rising incomes. Mark Elvin summarizes this perspective:

In late traditional China economic forces developed in such a way as to make profitable invention more and more difficult. With falling surplus in agriculture, ... cheapening labor but increasingly expensive resources and capital, with farming and transport technologies so good that no simple improvements could be made, rational strategy for peasant and merchant alike tended in the direction not so much of labor-saving machinery as of economizing on resources and fixed capital. Huge but nearly static markets created no bottlenecks in the production system that might have prompted creativity. When temporary shortage arose, mercantile versatility, based on cheap transport, was a faster and surer remedy than contrivance of machines (1973, pp 314-315).

On the supply side, many authors have proposed that declining interest in science among China's educated elites precipitated a slowdown in technical change. The former is sometimes related to a shift in Chinese thinking: Elvin detects "a change in the attitudes of philosophers towards nature" which meant that "Interest in systematic investigation was short-circuited" so that "There were ... no advances in science to stimulate advances in productive technology" (1973, p. 204). Benjamin Elman forcefully rejects the "scholarly consensus about the alleged failed history of science in China" (2005, p. 420). Despite this more favorable assessment, he concedes that the transmission of Western scientific knowledge was hampered by the demise of the Jesuits, by the growing scientific prominence of Protestant regions with few links to China, and by the reluctance of both Protestants and Catholics to translate materials about the solar system or evolution that seemed to contradict Christian theology (2005, pp. xxxii, xxxiii, 350).

Justin Lin (1995) postulates two sources of innovation: experience, and science-based experimentation. For the former, the probability of innovation is directly related to population size. The latter, however, requires experimentation, which Lin contends developed less fully in China than in Europe; following others, he attributes this to incentives that encouraged able youths to pursue Confucian education in the hope of entering the ruling bureaucracy.

The work of others would question the impact that Lin attributes to China's system of Confucian education. Robert Allen (2009), citing European experience, argues that new scientific knowledge played only a modest role in Europe's advance. Elvin adds that "Chinese technology stopped progressing well before basic scientific knowledge had become a serious obstacle" (1973, p. 298). Joel Mokyr (2002, 2009), though, insists that basic science became increasingly important and indeed, indispensable to the second and third waves of industrialization.

Historically, the Chinese state contributed to generating and diffusing innovations, for example in hydraulics, which may have compensated for limited private-sector dynamism. Mokyr (1990) argues for a major post-Song retreat in the Chinese state's predisposition toward, and contribution to developing new technologies. He sees the Ming-Qing state as somewhat inhospitable to innovation. Such changes, if they occurred, may have arisen from fears about 
possible dislocation associated with technical and economic change, a concern that certainly figured in periodic official efforts to limit external trade. ${ }^{28}$

This shifts the focus to China's political institutions, specifically, to the capacity of the political unity that prevailed throughout most of Ming and Qing to choke off political competition. European cities enjoyed considerable autonomy, developing their own charters and civil codes. Intense competition between cities and states allowed individuals to relocate to favorable environments - opportunities that were largely absent within the unitary Ming-Qing polity (Mokyr 1990, chap. 9).

Historical analysis of the traditional Chinese state and institutions has long reflected simplistic frameworks based on oriental despotism (Karl Wittfogel 1957/1976) or class struggle (for example Wang Ya'nan 1981/2005). Recent literature partially corrects these limitations by emphasizing that benevolent imperial rule taxed the peasantry lightly, protected private property rights and permitted the operation of well-established markets in land and labor. ${ }^{29}$

While the traditional framework of oriental despotism may be misleading and overly pessimistic, the state - especially its absolutist features and highly centralized political and fiscal regime - figures prominently in the formation of property rights, contract enforcement and incentives, and therefore in the economic dynamics of imperial China. In particular, the classic dilemma of government commitment posed by Douglass North - growth requires a strong state to secure property rights, but an overly powerful state may threaten the security of private ownership - recurs throughout two millennia of Chinese dynasties.

Recent work by Tuan-hwee Sng (2010) addresses the link between geography and fiscal capacity in a world of pre-modern communication and transport. Sng's work highlights the need for a full account of the economic achievements and failures of China's imperial system to address the impact of China's enormous geographic and demographic size on the agency costs inherent in decentralized governance structures, fiscal capacity, and a set of complementary institutions, most notably, property rights, which North and others (North 1994; North and Robert Paul Thomas 1973, North, Wallis and Weingast 2009) see as crucial to the genesis of modern economic growth.

China's stunning economic rise beginning in the late $20^{\text {th }}$ century raises new questions. Now that recent events oblige us to recognize the dynamic capabilities inherent in Chinese social formations and economic structures, why did realization of this vast potential occur only in the past three decades? In particular, why is there no sign of accelerated growth during the closing decades of the Qing era, roughly from 1870-1910, when China experienced substantial openness to domestic market forces and to international flows of trade and investment, substantial influx of engineering and organizational technology, opportunities to populate fertile new territories in Manchuria and to repopulate farmland abandoned during the fiercely contested Taiping rebellion (1854-1865), as well as considerable internal stability under a regime that demonstrated modest interest in reform? Whatever the obstacles to accelerated growth during these decades, why did China's greatest growth spurt occur more than a century after her opening?

\footnotetext{
${ }^{28}$ See Elman 2005 for an alternative interpretation.

${ }^{29}$ Kenneth Pomeranz (2000) and R. Bin Wong (1997) discuss factor markets and taxation; Debin Ma (2011b) reviews China's traditional legal institutions.
} 
We see institutional analysis as a promising avenue for understanding late Qing obstacles to modern growth, the erosion of these constraints during the course of the $20^{\text {th }}$ century, and the dynamics of China's recent growth spurt. Our approach follows recent efforts of economists, notably Daron Acemoglu, Simon Johnson and James A. Robinson (2005) and Acemoglu and Robinson (2012) to elucidate the contribution of institutional structures and institutional change to long-term economic growth.

The task is not simply to explain China's delayed industrialization, but rather to account for a multi-stage process that includes long periods of limited advance, followed by an unprecedented expansion. Our approach will rely on the perspectives of political economy and institutional analysis, methodologies that, in our view, have much to contribute and that recent studies of Chinese economic history have often neglected.

\section{THE POLITICAL ECONOMY OF THE TRADITIONAL CHINESE STATE}

With basic political structures and social arrangements displaying substantial continuity throughout the Qing era, which lasted from the mid- $17^{\text {th }}$ to the early $20^{\text {th }}$ centuries, how can we connect generally stable institutional formations to highly variable economic outcomes? While recent research is not without controversy, there is no disagreement about overall trends in the Qing economy, in which a generally prosperous $18^{\text {th }}$ century gave way to a period of growing economic difficulty after 1800 during which China was slow to grasp new opportunities radiating from the British industrial revolution. Extending the task to encompass potential links between Qing institutions and China's recent growth explosion broadens the challenge confronting efforts to develop a cohesive analysis of long-term outcomes. ${ }^{30}$

We begin by postulating the existence of several key structures. We then follow the logic of incentives and constraints to sketch a heuristic model of China's traditional political economy. The result is a surprisingly comprehensive framework that illuminates the underpinnings of Qing stability and success, pinpoints mounting tensions and constraints that gradually reduced the system's effectiveness, and reveals specific barriers to fundamental reform.

We focus on interactions among four key actors: the imperial household, the bureaucracy, local elites, and the masses. The bureaucracy refers to imperially appointed officials; focusing on the 1880s, Chung-li Chang [ZHANG Zhongli], tabulated 23,000 officeholders $-2,600$ in the imperial court, 13,000 provincial and local officials, and 7,000 military officers $(1962$, p. 38). The local elite includes retired imperial appointees and graduates of provincial and metropolitan civil service examinations who were eligible for imperial appointments but held no formal posts, as well as holders of lesser degrees and non-degree

\footnotetext{
${ }^{30}$ These challenges are evident in Francis Fukuyama's recent work (2011). Recognizing many similarities between Qing and PRC political institutions, but observing high-speed growth only after 1978, Fukuyama contends that: "What China did not have was the spirit of maximization that economists assume is a universal human trait." He goes on to claim that "It is far likelier that cultural attitudes towards science, learning, and innovation explain why China did so poorly in the global economic race in previous centuries, and is doing so well at the present, rather than any fundamental defect in political institutions." We disagree on both points.
} 
holders who possessed sufficient land, education, wealth or reputation to merit recognition as part of the local (or national in the case of prominent salt merchants) elites, along with their extended families. ${ }^{31}$

While all institutions are in principle endogenous, we take as given Song political institutions that had evolved over the previous millennium and endured until the 1911 collapse of the Qing regime. After describing these legacies, we explain how incentives surrounding these institutions shaped the behaviour of the four groups that populate our model: the throne, bureaucracy, gentry, and commoners. The results illuminate fundamental dimensions of political economy under the Chinese imperial system.

\subsection{Key Political Institutions}

From the $10^{\text {th }}$ century on, much of what is now regarded as China was under nearly continuous unitary rule. ${ }^{32}$ Map 1 depicts the borders of the Ming (1368-1644) and Qing (16441911) empires. Although Qing military and diplomatic prowess extended their territory far beyond the boundaries of Ming rule, we assume an empire of fixed size. We also posit the presence of key institutional features which we take as given or exogenous: central and unitary imperial rule; a hierarchical, meritocratic system of staffing the imperial bureaucracy; and a land-based fiscal system. We briefly examine each of these before pursuing their larger implications.

The consolidation of political control in the hands of the Song emperors represents an important departure from the preceding four or five centuries, during which the power of the throne was checked by a relatively autonomous imperial cabinet and by regional aristocrats. By the beginning of Song, absolute power had become vested in the emperor. Moreover, there were no institutional constraints on the Emperor other than a vaguely defined principle of legitimacy emanating from the so-called "mandate of heaven." As Ray Huang explains in the context of Ming:

None of the deterrents to unlimited exercise of imperial power - including Confucian morality, reverence for the standards set up by imperial ancestors, public opinion, or the influence of senior statesmen - had the effect of law. If the emperor chose to defy all these and was determined to exercise his absolute power to the full, there was no way of checking $\operatorname{him}(1974$, p. 7).

\footnotetext{
${ }^{31}$ Chang tabulates the ranks of gentry, which in his study includes all holders of both earned and purchased examination degrees, at 1.09 million before (i.e. about 1850) and 1.44 million after (i.e. about 1870) the Taiping rebellion (1851-1864). Assuming an average of five persons per gentry household, he concludes that the gentry population amounted to approximately 1.3 percent "of the whole population. . in the first half of the nineteenth century" and to "well over seven million. . . . [or approximately] 1.9 percent of the total population" after the defeat of the Taipings (1955, pp. 111-112, 139-141).

${ }^{32}$ Debin Ma (2012) traces the historical phases of unification and fragmentation in Chinese history.
} 
With the elimination of an aristocracy or any other autonomous intermediary social or political group, governing the empire's vast territories required a bureaucratic structure that extended beyond the imperial household. ${ }^{33}$ China's administrative needs included border protection, internal security, provision of public goods, and the collection of sufficient tax revenues to finance these activities as well as the consumption of the imperial court.

From the 8th century, bureaucratic recruitment became increasingly impersonal and meritocratic. Candidates for official positions were primarily selected from successful graduates of a standardized progression of periodic civil service examinations open to most male commoners. Examinations took place at the county, provincial and national levels. Successful candidates received degrees according to prefectural and provincial quotas, which meant that imperial officials were recruited nationwide, in numbers roughly proportional to provincial populations (MIYAZAKI Ichisada 1976, Benjamin Elman 2000).

Examination contents were rooted in Confucian ideology, which itself reflected the ideal of a hierarchical, patrimonial structure with the emperor at the top.34 Successful candidates (often called degree holders) commanded immense prestige; they enjoyed lifelong tax exemptions and legal immunity. They constituted a non-hereditary elite whose welfare was intimately tied to the survival and success of the imperial regime. A poem by the Song emperor eloquently sketches the connection between learning, wealth and power that the examination system imprinted in the consciousness of Chinese households (MIYAZAKI 1976, p. 17):

To enrich your family, no need to buy good land:

Books hold a thousand measures of grain.

For an easy life, no need to build a mansion:

In books are found houses of gold.

Going out, be not vexed at absence of followers:

In books, carriages and horses form a crowd.

Marrying, be not vexed by lack of a good go-between:

In books there are girls with faces of jade.

A boy who wants to become a somebody

Devotes himself to the classics, faces the window, and reads.

This examination system offered the prospect of upward mobility, possibly over several generations, to commoner households. Coupled with the "rule of avoidance," which proscribed officials from serving in their home county, prefecture, or province, and the frequent rotation of incumbent officials, this recruiting system endowed the imperial state with both talent and legitimacy.

\footnotetext{
${ }^{33}$ QIAN Mu 1966 and Ping-ti Ho, 1962, pp.17-19 describe the limited extent of hereditary aristocracy in Ming and Qing. Mark Elliot (2011) focuses on the role of Manchu elites under the Qing.

${ }^{34}$ This concept of the state is in many ways an extension of the Confucian ideal of a patriarchal household. With the elimination of hereditary aristocracy, the transition from feudalism to central rule extended the stand-alone imperial household (家) into the national sovereign (国). The literal translation of the Chinese character for nation-state (国家) is "state-family" or what Max Weber (1951/1964) described as a patrimonial or "familistic" state." See Ma 2012a.
} 
In principle, the emperor commanded property rights over all factors of production. Imperial ownership of land and labor is expressed by the traditional notion of 'Wangtu wangmin (王土王民, king's land, king's people/all land and all people are owned by the sovereign)', which appeared in The Book of Songs compiled during the age of Warring States (403-221 B.C.). ${ }^{35}$ Despite the emperor's theoretical ownership, early rulers assigned land to individual households in return for payment of taxes. The Tang state (618-907) began to relinquish control of land ownership, leading to the emergence of a system under which private owners held de facto ownership of land and assumed personal responsibility for paying land taxes, which became the cornerstone of imperial finances. Thus de jure imperial property rights gave way to de facto rights to taxes. In parallel fashion, private labor markets gradually replaced systems that had formerly required households to provide labor services to the state.

\subsection{Toward a Heuristic Model}

With absolute hereditary power and without formal constraint on its rule, the biggest threats to China's imperial household came from external invasion or internal insurrection. Rebellions were an enduring feature of Chinese history. A well-known admonition to the Tang emperor to the effect that people can support or upend rulers just as water can float or overturn a boat provided a constant reminder of possible insurrection. Confucians denounced excessive fiscal extraction: the Tang scholar-official LIU Zongyuan "compared taxes to the venom of a snake" (http://www.newworldencyclopedia.org/entry/Liu Zongyuan).

External security required tax revenues to finance defence spending. In addition, the state needed to support the imperial household and finance the costs of running the bureaucracy and of supplying public goods. Concerns about internal rebellion, however, meant monitoring the amount and incidence of taxation to ensure a satisfactory level of income and welfare for the populace.

Countless examples illustrate the potential for violent tax resistance. Madeleine Zelin recounts a Qing episode in which a newly appointed magistrate, seeking to collect overdue land taxes in Shanghai county, ordered the arrest of defaulters, including a headman initially assigned to pursue tax evaders. The result was chaos:

while a mob attacked the magistrate's deputy," the wife of the arrested headman committed suicide. When "the magistrate, accompanied by an entourage of yamen runners, went on a tour of inspection. . . a large crowd led by [relatives of the deceased woman]. . . stoned the. . . magistrate's retinue and drove the magistrate out of town. . . . Similar riots also broke out. . . after the magistrate [of another district] personally directed the collection of old tax debts (1984, p. 255).

\footnotetext{
${ }^{35}$ KISHIMOTO Mio (2011) summarizes imperial ownership and the nature of traditional Chinese property rights.
} 
China's fiscal system was centered on the taxation of privately-owned land. Data for 1753, a year in which, according to Yeh-chien Wang, official fiscal data were "more reliable and complete" than at other times, show land taxes accounting for 73.5 percent of officiallyrecorded revenue, with the balance coming from the salt tax (11.9 percent), native customs (i.e. taxes on internal and foreign trade, 7.3 percent) and miscellaneous taxes ( 7.3 percent). ${ }^{36}$ For simplicity, we assume a fixed stock of taxable land, so that total fiscal revenue depends on the official tax rate on a unit of land and the size of the bureaucracy devoted to tax collection. Government revenue was increasing in both: raising the tax rate generated more revenue, as would adding more tax collectors. Fiscal administration also involves expenditures: adding tax officials increases the government's wage bill and outlays on maintaining tax offices.

In this setting, the problem facing the Emperor is to determine the tax on land and the size of the bureaucracy to maximize net fiscal revenue (total tax collection less administrative costs), subject to leaving farm households with a satisfactory level of after-tax income. In this quest, the Emperor needed to consider indirect agency costs that arise in any hierarchical organization because of informational asymmetries and imperfect monitoring. Agency costs were especially pertinent in China, where imperially-appointed officials were entrusted to govern far-flung regions linked only by networks of slow pre-industrial transport and communication. $^{37}$

As imperial agents, local officials were expected to treat taxpaying households equitably and to provide full and honest accounts of tax collections. But, like governments everywhere, China's bureaucracy often veered toward the pursuit of self-interest. The problem was further compounded by limited official fiscal allocations to local governments, which forced county magistrates to impose informal levies unsanctioned by any imperial decree simply to maintain their offices and perform their duties. Such conditions made it difficult for both external monitors and the bureaucrats themselves to separate what might be called "public-interest malfeasance" from peculation intended to secure illicit personal gain. Officials employed a host of strategems to pillage the public purse, exaggerating the severity of harvest shocks, overstating the extent of tax arrears, colluding with local landholders to remove land from the tax rolls, or simply diverting public funds for their own benefit.

The land tax system created sharp conflicts between local officials and land-owning households, including local elites, who often held substantial acreage. Tax collectors often bullied ordinary households, for example by manipulating weights and measures to extract payments in excess of the legal tax obligation. The prevalence of unofficial tax-farming provided ample opportunity for officials to appropriate revenues for their private benefit. Commoners resisted such impositions (and also sought to escape taxation) through violent tax resistance and by allying themselves with local gentry. The gentry used their elite status and the dependence of understaffed local administrations on their active cooperation as levers to reduce or even escape tax obligations, typically with the connivance of local officials.

\footnotetext{
${ }^{36}$ Wang $(1973$, pp. 68,80$)$. The dominant share of land tax in total revenues persists throughout the Ming and Qing dynasties.

${ }^{37}$ Prior to the advent of railways, travel from the capital to Shenyang required 30 days, to Xi'an or Wuhan 50 days, to Nanjing nearly 50 days, to Guangzhou 90 days, etc. (Joseph B.R. Whitney 1970, p. 47).
} 
These circumstances meant that the intended and actual outcome of efforts to collect land taxes differed widely. Some land-owners, particularly small-holders without the protection of elite patrons, were squeezed by the collectors, and ended up making payments that exceeded their statutory obligation. Gentry landowners, as well as commoners enjoying their patronage, might persuade or bribe officials to accept fractional payments rather than demanding the statutory amount. ${ }^{38}$ Officials' need for gentry cooperation made it difficult for magistrates to resist gentry pressures for informal tax relief. Finally, there was considerable revenue leakage, as clerks, runners, and officials siphoned public funds into private purses.

Chinese emperors, keenly aware of these difficulties, established institutions aimed at limiting the impact of agency costs. Confucian ideology, which prescribed codes of behaviour for all social groups, including officials, acted to promote upright behaviour even in the absence of effective monitoring. Frequent rotation of officials, as well as the "law of avoidance," which barred officials from serving in their home districts, aimed to direct official loyalties toward the throne. The Censorate, a branch of the central bureaucracy, dispatched roving observers to serve as the emperor's eyes and ears by reporting official malfeasance directly to the throne.

These internal checks, which entailed additional administrative costs, could not fully resolve the conflicts inherent in the centralized hierarchy. The Censorate itself was plagued with corruption, as is its contemporary counterpart. ${ }^{39}$ Formal bureaucratic posts often evolved from personal appointments in which the emperor assigned trusted lieutenants to the task of improving the center's grip on outer layers of administration. Over time, these positions merged into the formal bureaucratic structure, leading to the assignment of fresh cohorts of inner court personnel to the (now enlarged) tasks of monitoring and control. This gradual multiplication of bureaucracy, which arose from internal dynamics unrelated to population growth or territorial expansion, contributed to what some historians have referred to as the "externalization" of the inner bureaucracy (QIAN Mu 1966, p.44, WANG Ya'nan1981/2005 pp. 48-49).

Writing in 1896, LIANG Qichao, a celebrated intellectual and reformer, noted this selfweakening aspect of the imperial bureaucracy, commenting that as rulers cannot trust their officials, they set up multiple layers of bureaucracy to check one another. In the end, nothing gets accomplished as no one takes responsibility. Moreover, lower level officials become more interested in pleasing their superiors than in serving the people (1896/1984, pp. 27-31). Liang anticipates G. William Skinner's observation that "Chinese history saw a secular decline in governmental effectiveness from mid-T'ang [i.e. from the mid- to late $8^{\text {th }}$ century] on to the end of the imperial era" as well as the findings of modern theorists who show how lengthening a hierarchy by adding new supervisory layers increases agency costs and generates organizational diseconomies of scale (Skinner 1977b, p. 19; Jean Tirole 1986; R. Preston McAfee and John McMillan 1995).

\footnotetext{
${ }^{38}$ Philip A. Kuhn describes how rural elites "undertook to pay their neighbors" taxes by proxy and fend off the tax agents' extortion" in return for fees (2002, pp. 81-82) and documents the Qing government's inability to suppress this illegal practice, primarily because of "how little local officials were willing to do about. . . . elite meddling in the tax system" (ibid., 90-91).

${ }^{39}$ A 2010 news report noted that "a former top anti-corruption official . . . was sentenced to death. . . for taking bribes." See http://news.xinhuanet.com/english2010/china/2010-09/09/c_13486543.htm.
} 
These agency costs defy precise specification, but represent some combination of informal taxation on individuals and households, rent extraction by bureaucrats, and lawful taxes that went unpaid as a consequence of elite manipulation. Formal land taxes impinged primarily on the income and welfare of ordinary farm households. Informal taxation, bureaucratic extraction and elite tax avoidance undermined the financial position of both the emperor and the non-elite populace. Agency costs limited the Qing system's potential to increase the level of formal taxation on land. ${ }^{40}$

In a slightly more complicated setting, the Emperor would set the formal tax rate on land and the size of the bureaucracy devoted to tax collection, and also determine the number of personnel monitoring the bureaucracy, all with an eye to maximizing formal fiscal revenue (net of collection and monitoring costs), but subject to an insurrection constraint, which represents the necessity, reinforced by Confucian ideology, of allowing sufficient after-tax income to focus popular attention on cultivation rather than revolt.

\subsection{What Kind of Political Equilibrium Emerged?}

This framework offers surprisingly powerful insight into a range of outcomes that describe the political equilibrium of the Chinese imperial regime. In what follows, we look at taxation, the size and activities of the state, the nature of property rights in land, informal taxation and corruption, the vested interests of the gentry, and the role of the legal system. We apply the term "equilibrium" because the implied outcomes were historically stable, mutually reinforcing and extremely difficult to alter, short of major shocks imposed from outside.

\subsubsection{Low formal taxation and small formal bureaucracy}

High agency costs associated with administration of the empire and concerns about insurrection steered imperial China toward outcomes built upon modest formal taxation, a small official bureaucracy, and a correspondingly limited scope of non-military activities financed from the public purse. Dynasty's long time horizon pushed in the same direction. ${ }^{41}$

\footnotetext{
${ }^{40}$ While agency costs constrain the ability to collect formal tax revenues, higher tax rates should increase agency costs as local elites intensify their efforts to avoid taxation, thereby increasing the burden on commoner households and probably raising collection costs as well.

${ }^{41}$ In a dynamic setting, we could represent the policy objective as maximizing the discounted present value of the imperial household's welfare, implying an important role for the imperial time horizon. The more dynastic the emperor's view, the longer the time horizon and thus the lower the discount rate used in these calculations. In Mancur Olson's (1982) framework based on the analogy of stationary and roving banditry, extending the ruler's time horizon would make the throne's interests more encompassing and less predatory, thereby contributing to a "virtuous equilibrium" of low extraction and high mass welfare.
} 
After rising during the early years as the new Qing dynasty re-established order, formal tax revenue expressed in silver taels remained fairly constant between 1700 and 1850, averaging around 36 million silver taels annually, of which approximately 70 percent came from taxes on land. ${ }^{42}$ With stable revenue and substantial population growth, per capita tax collections fell steadily: By 1850, per capita revenue was less than half the level for 1700 . Nominal revenues rose sharply in the late $19^{\text {th }}$ century, but the increase was modest in real terms. The share of government revenue in total output during Qing was also low: Yeh-chien Wang finds that late $19^{\text {th }}$-century land taxes represented 2-4 percent of the produce of the land in most areas, although they may have consumed a larger share in the prosperous Yangzi delta region. Total government revenue from all sources amounted to roughly 2.4 percent of net national product in 1908 ( Yeh-chien Wang 1973, pp. 80, 128, 133), suggesting that tax revenues remained well below five percent of total output throughout the Qing period.

Historical compilations summarized in Table 2 indicate that tax revenues under the Song and Ming dynasties exceeded those in the Qing period, both in aggregate and in per capita terms (Guanglin Liu 2005). While the Song figures are subject to considerable uncertainty, the ordering implied by these data matches information on the size of Chinese armies during the three dynasties (IWAI Shigeki 2004, p. 33). (See TABLE 2)

Figure 1 displays trends in nominal, real, and per capita fiscal expenditure during the Qing dynasty. Nominal expenditure showed little fluctuation for approximately 200 years beginning in the early $18^{\text {th }}$ century. Population growth and inflation produced an early decline in real and per capita expenditure, followed by trendless fluctuation during the first half of the $19^{\text {th }}$ century. All three nominal measures rose during the final half-century of Qing rule, with per capita expenditure in the early $20^{\text {th }}$ century regaining levels recorded during the initial period of Qing rule. (See FIGURE 1)

Comparative data shown in Table 3 demonstrate the Qing dynasty's limited fiscal capacity. During the late $18^{\text {th }}$ century, per capita revenues of the leading European states, expressed in grams of silver, were 15-40 times comparable figures for Qing China. England's revenue actually surpassed the comparable figure for the immensely larger and more populous Qing Empire! Per capita revenues, which remained roughly constant over long periods under the Qing, tended to increase elsewhere. Expressing the tax burden in terms of the number of days an unskilled urban laborer would have to work in order to earn the equivalent of the average individual tax payment provides an alternative view of the Qing empire's modest fiscal capacity. (See TABLE 3)

Limited revenues and the prospect that adding officials could undermine administrative effectiveness meant that the size of the bureaucracy lagged far behind the growth of population. Indeed, the number of counties (xian), units ruled by magistrates who occupied the lowest rung of the official hierarchy, hardly changed after Han (206 BC-220 AD) times. Despite a vastly larger population and territory, Qing China had only 1,360 counties compared to 1,230 under the Song (Skinner 1977b, p. 19). Limitations on the size of the bureaucracy help explain why the imperial administration never penetrated below the county level. With a near-static administrative structure, population growth meant that average county populations during Qing

\footnotetext{
${ }^{42}$ The Qing monetary system included multiple silver taels, which typically represented 35-40 grams of pure silver. For details, see Frank H.H. King (1965) and Eduard Kann (1975).
} 
reached a large multiple of comparable Song figures. This increased the administrative burden facing local magistrates and magnified their dependence on the cooperation of local gentry, which in turn reinforced the pressures mandating a low-tax regime, as efforts to increase taxes would place local officials in direct conflict with the same elites whose support was essential to managing local affairs and preserving social order.

A $19^{\text {th }}$-century example from Xinhui, Guangdong illustrates the helplessness of local officials in the absence of gentry cooperation. When the Qing state imposed likin (lijin) taxes on domestic trade, the local palm-leaf guild raised no objection. But this seemingly obscure group blocked subsequent efforts to increase the tax rate:

When the guild resisted. . . there was nothing the magistrate could do but request a waiver [exempting the guild from the higher likin rates]. ... He was unable to survey the palmgrowing areas to tax them directly, because the guild and its supporters refused to cooperate. He was unable to muster community support. . . . when he called a meeting of local gentry. . . no one came (Susan Mann 1987, p. 130).

Similar conditions existed elsewhere. While bearing the emperor's imprimatur, local magistrates were lone outsiders facing tightly-knit communities that often included several hundred thousand residents. The inescapable reality of gentry power emerges most strikingly from the decision of the Kangxi emperor (r. 1662-1722), among the strongest Qing rulers, to abandon a proposed empire-wide cadastral survey in the face of elite resistance. The outcome was continued use of obsolete Ming land registers coupled with a permanent freeze on tax quotas - "a gigantic concession to local gentry and landlords" (John F. Richards 2003, p. 124). Kangxi's successor, Yongzheng (r. 1722-1735) sought to incorporate informal taxes and surcharges into the formal tax base in an effort to restrain local corruption and stem the leakage of resources from the public purse. Here again, top-down imperial reform failed to overcome resistance from below, now from local magistrates who valued the discretion (and opportunities for rent extraction) associated with the traditional system. Since informal local revenues were essential to local governance, the information asymmetry surrounding these revenues protected them from extraction by higher-level officials (Zelin 1984, chap. 7, Debin Ma 2011a).

Under these circumstances, well-informed emperors who understood the dangers of excess tax demands on commoners as well as the revenue leakage arising from official peculation and gentry manipulation might reasonably conclude that raising the rate of land taxes was not a practical option. Given the limited size of the imperial household and the throne's desire for dynastic longevity, imperial ideology evolved toward fixing a revenue target for normal years (in the absence of harvest failure or external crisis), an outcome famously encapsulated in the Kangxi emperor's 1712 proclamation freezing nominal land taxes in perpetuity (Ma 2011a).

\subsubsection{Limited state capacity}

Like all revenue-constrained pre-modern empires, Qing public spending was limited to programs that addressed fundamental issues of external and internal security. Expenditures on 
the military and border defenses protected the largely sedentary agrarian populace. The central government's outlays on civilian public goods focused on measures intended to stabilize and increase agricultural productivity - for example investments in water control and irrigation. The state operated a network of granaries in an effort to limit price fluctuations and stave off famine; this program may explain why increases in grain prices following Chinese crop failures were "moderate" (20-70 percent) in comparison with "the worst European famines where prices doubled, tripled, or quadrupled" (Lillian M. Li 2007, 247; also see Peter Perdue 1987 and Will, Wong and Lee 1991).

Such programs contributed to mass welfare and thus supported the longevity of the imperial system. They also relied on local contributions, highlighting both the need for magistrates to secure elite cooperation and the difficulty of reconstructing a complete picture of government revenues. Perdue (1987) shows how Qing officials worked with local gentry to expand irrigation and flood control in Hunan province. Similar arrangements led to the construction and maintenance of major projects that delivered large-scale economic benefits for centuries: the Grand Canal, spanning a north-south route over 1,000 miles in length between Hangzhou and Beijing, completed during the $7^{\text {th }}$ century (Jane Kate Leonard 1996); and Dujiangyan, an even older project located in the western province of Sichuan, that cleverly combines flood control with irrigation (Joseph Needham 1971, 288-296).

To guard against external threats, the Qing, like previous dynasties, employed a mixture of attack, defense and diplomacy. Perdue $(1996,2005)$ shows how Qing officials harnessed mercantile interests to equip and supply extended military campaigns in the Empire's remote western borderlands. The same logistic capabilities enabled Qing armies to cross the Himalayas and force Nepal's fierce Gurkhas to recognize Manchu over-lordship.

China's large size, limited revenues, long communication lines, and small bureaucracy influenced the nature as well as the scale and scope of official activity. A late $19^{\text {th }}$ century commentator described the focus of the central government as "registering and checking the actions of various provincial administrations [rather] than. . . assuming a direct initiative in the conduct of affairs" (William F. Mayers 1897, pp. 21-22). Man Bun Kwan finds that the Board of Revenue, which bore major responsibility for managing the imperial salt monopoly, was "primarily a transmission center of documents and repository for ledgers. . . [that] rarely initiated policy" (2001, p. 32). Frank King notes that even in the monetary sphere, a central government responsibility, "the Board of Revenue could not be the source of a coherent monetary policy. It had no power to inspect the quality of provincial coins. . . I It could comment on provincial memorials only if they were referred to the Board. . . ." (1969, p. 34). Julia Strauss (1998) aptly summarizes the key goal of the Qing central administration as "system maintenance rather than maximal efficiency" (p. 14).

\subsubsection{De-facto or informal private property rights}

This focus on stability and dynastic longevity encouraged emperors toward pragmatism rather than absolutism. Late Tang reforms that shifted emperors' main source of tax revenue from labor to land prompted the state to relinquish its theoretical control of land tenure and 
support the emergence of the de-facto family-based owner-tenant system of private landholding and household cultivation that dominated the economy of imperial China for the next millennium. Such processes of bottom-up institutional innovation - visible both in Tang and in the 1970s shift from collectives to the household responsibility system - involved the tacit acquiescence of rulers who chose to overlook widespread infringements of existing rules.

The emerging private land ownership rights included residual claimancy; the right to rent, sell or mortgage; and the right to bequest. Recognition of these rights allowed private owners rather than the state to capture the benefits associated with rising productivity, land reclamation, and population growth. If households became unable to farm their plots or chose to shift occupations, the opportunity to sell or rent land use rights allowed them to capture the returns to their investment in the land.

The Tang reforms encouraged the development of increasingly deep and sophisticated markets for land in which layers of ownership and user rights could be purchased, sold, rented, mortgaged, and divided. ${ }^{43}$ Ownership of a single plot could be vested in separate parties endowed with rights over the surface and sub-surface respectively - the so-called yitian liangzhu (two lords to a field) or yitian sanzhu (three lords to a field) system - rights that could then be sold, leased, or used as collateral. Tenants as well as owners could freely exchange their access rights. The multiplicity and divisibility of rights to land helped ordinary villagers to defend their livelihoods in an inherently risky environment. They also gave rise to complex arrangements: LONG Denggao (2010) reports a single plot of land with over 100 separate owners, some with shares as small as 1/608.

Commerce experienced a similar transformation under the Tang, as earlier systems "of administered trade became increasingly arduous and expensive to enforce. . . a process of trial and error. . . punctuated by the periodic re-imposition of controls. . . [led to] a general withdrawal by government from the minute regulation of commercial affairs" and a notable expansion of privately established markets and private mercantile activity (Skinner 1977b, pp. 24-25 - note the obvious parallel with China's recent reform experience).

De facto or informal property rights in both land and commerce evolved within a unitary hierarchical empire without the representative institutions, independent cities, or autonomous legal agents that appeared in Western Europe.

\subsubsection{Informal taxation and rent extraction}

Land taxes collected from rural communities were mostly remitted to higher levels of government. Madeleine Zelin estimates that county magistrates retained approximately onefifth of official land tax collections to meet local needs (1984, p. 27). Much of the retained funds went to fulfill imperially-mandated outlays, for example provisioning military forces and

\footnotetext{
${ }^{43}$ Land transactions were often recorded in written documents, many of which survive in libraries and archives. MURAMATSU Yūji (1966) and ZHANG Deyi et al (2009) provide examples of documents recording land transactions.
} 
maintaining imperial relay stations. What remained was not sufficient to operate government offices, pay the magistrate's salary, and support the required complement of secretaries, clerks, runners and personal servants. ${ }^{44}$ This reflects both the state's limited fiscal resources and the center's deliberate effort to limit the growth of local power bases by constraining locally available fiscal resources.

To make ends meet, sub-national officials relied on informal or extralegal surcharges. Informal taxation, which was "an established practice in the mid-eighteenth century as it was necessary for keeping public administration at work" (Yeh-chien Wang 1973, p. 72), blurred the distinction between legitimate and corrupt official behavior, and thus complicated efforts to detect and deter the diversion and embezzlement of public funds. The weak financial position of local governments increased the dependence of magistrates on local elites, who

played a crucial role here by helping the magistrate with his duties; from the maintenance of water conservancy works to the organization of local defense corps. ... the magistrate, as a non-native of the region where he held office, was to a certain extent dependent on the local elite's advice in carrying out his magisterial duties, as well as on their support in the leadership of local people. ... In 'reward' for its 'efforts,' the local elite was in turn also in a position to enjoy certain tax exemptions, and moreover, to falsify land registers and population reports, or, even, to appropriate tax revenue which normally would have passed to the state (Harriet Zurndorfer, 1989, pg. 3).

Zelin itemizes these informal revenue sources, which ranged from the levying of surcharges, manipulation of weights, measures and currency conversion in tax collection, falsifying reports, shifting funds across fiscal years, and concealing tax revenue from commerce and from newly reclaimed land to extracting contributions and donations from local farmers and merchants. She chronicles an episode in $18^{\text {th }}$-century Jiangsu province in which an investigating magistrate discovered widespread embezzlement of official funds: "there was not a prefecture, chou or hsien [county] in the region in which [secret records providing a true picture of land-ownership and tax payments]. . . were not compiled" (1984, p. 240). ${ }^{45}$ Provincial officials solicited gifts from their bureaucratic subordinates and skimmed funds by inflating the cost of official purchases (1984, pp.46-71). Reliance on informal local taxation and the employment of unofficial staff for public administration often led to the privatization of public services. $^{46}$

\footnotetext{
${ }^{44} T^{\prime}$ ung-tsu Ch'ü indicates that county-level governments employed several hundred (and in some cases, several thousand) clerks, several hundred (and in some cases, over 1,000) "runners" (i.e. messengers, guards, policemen and other menial employees), and 10-30 personal aides (1962, pp. 39, 56, 59, 77). Some of these personnel received salaries from the magistrate; others received no salary, but imposed irregular fees on citizens who sought access to official services.

${ }^{45}$ Franklin L. Ho (1967) reports similar practices in early $20^{\text {th }}$-century Hebei province.

${ }^{46}$ Ch'ü (1962) offers a vivid portrayal of county clerks extracting bribes with the threat of delaying legal cases submitted, runners demanding "chain-release money" from the families of accused criminals who might otherwise be chained or tortured, retaining part of the goods recovered from thieves, or sometimes resorting to outright extortion of wealthy residents. The porters who guarded magistrates' offices expected tips for accepting documents or warrants.
} 
In a world of rising population, static overall and declining per capita revenues restricted the center's capacity to mobilize resources either to implement new administrative initiatives or to meet national emergencies. Although Qing ideology celebrated the beneficial welfare consequences of a "small state," we cannot determine whether this reflected the rulers' initial belief or represents a rationalization of unavoidable realities. Limited revenue and the lack of fiscal provision for local governance obliged emperors to accept substantial financial abuse, relying on ideology and occasional severe punishments to deter extreme behavior. ${ }^{47}$

The ubiquity of irregular taxation explains the apparent contradiction between the low rates reflected in the receipts of the Board of Revenue (see Tables 2 and 3 above) and the popular image of Ming and Qing as rapacious regimes. The Kangxi-era governor-general of Shaanxi and Gansu placed extra-legal surcharges at 40-50 percent of the official tax quota (Zelin 1984, p. 73). Yeh-chien Wang argues that such imposts were less severe, at least in 1753, a year for which the historical record is particularly rich; Wang concludes that "nonstatutory surcharges amounted to as much as the statutory ones, which generally ranged from 10 to 15 percent of the [authorized tax] quota" (1973, p. 69).

Information about the overall incomes of office-holders provides added perspective on the impact of the tax system. While estimates of unrecorded payments are always hazardous, the carefully documented work of Chung-li Chang [ZHANG Zhongli] concludes that the total incomes (including receipts from landholding and other non-official activities) accruing to imperial appointees during the 1880s may have amounted to twenty times the official payments associated with their positions and that gentry households, while comprising roughly two percent of the population, received 24 percent of national income, enjoying per capita disposable incomes approximately 17.7 times the average for commoners (1962, pp. 326-329). Chang also finds that informal income obtained by sub-provincial office-holders alone approached 60 million silver taels, equivalent to three-quarters of the central government's recorded annual revenue of 80 million taels during the 1880 s $(1962,40,42,328)$.

Chang's figures, however crude, reveal the capacity of officials at all levels to extract wealth from the private sector and help to explain the huge vested interest of Chinese elites embedded in what was, after all, a conquest dynasty led by the descendants of Manchu invaders whom most Chinese perceived as "barbarians."

\subsubsection{Law, economic security and patronage}

Formation and disposition of property rights are closely linked to the legal system, which, as in any nation, exerted substantial influence over Ming-Qing economic activity. Chinese emperors, faced with the task of maintaining stability while seeking to govern a vast land mass with a tiny corps of officials, required sufficient flexibility to strike quickly and powerfully at potential nodes of countervailing power - aside from the gentry, who, as noted earlier, were indispensable bulwarks of the status quo.

\footnotetext{
${ }^{47}$ Ping-ti Ho describes the use of selective capital punishment to control Qing officialdom (1962, 293295). The People's Republic employs similar tactics.
} 
In the legal sphere, these requirements point to a system that is controlled by the official hierarchy while remaining subject to imperial discretion. This is exactly what we observe. Under imperial rule, as in the PRC, the Chinese system views legal processes as a subsidiary function of the administrative hierarchy. In China, as in Rome, the emperor was the source of law. The Tang dynasty established an elaborate and systematic criminal code that was largely retained by its successors. Modifications arose primarily from occasional imperial interventions that extended or contravened existing codes; such actions constituted new laws or sub-statutes that served as precedents for subsequent decisions (SHIGA et al pp. 12, 120-121; SU Yegong 2000, chap. 9).

Legal outcomes reflected ideological orthodoxy and social privilege. The punishment inflicted upon a son for attacking his father or a wife for injuring her husband was more severe than if the roles were reversed. Trials of officials or gentry members could only be conducted by officials with higher administrative rank; such prosecutions usually occurred only after the accused was demoted or stripped of his official rank, and arrangement mirrored in China's current justice system, which imposes internal party discipline in advance of criminal prosecutions. The imperial system was far from arbitrary. Criminal verdicts followed elaborate penal codes and were subject to mandatory review; capital cases received the emperor's personal scrutiny (Ma 2011b).

While county magistrates also ruled on civil and commercial as well as criminal matters, broad swathes of economic and social life were governed by private custom, with disputes adjudicated and sanctions imposed by family, clan, and village elders, by local gentry, and by mercantile associations (e.g. Fu-mei Chen and Ramon Myers 1978, 1989/1996). Unlike Western Europe, where autonomous legal professionals contributed to the formalization of private customs and rules and the specification of property rights, the Chinese hierarchy viewed nonofficial legal specialists with suspicion. Legal secretaries who assisted county magistrates were not on the official roster, but were personally hired and paid by the magistrates. The Ming code banned "incitement to litigate"; the Qing went further, criminalizing the occupation of "litigation master," a profession remotely resembling modern-day lawyers (Melissa Macauley 1998). This explains the curious co-existence of the proliferation of private customs and rules with what many Western observers view as the absence of formal civil or commercial law (Jerome Bourgon 2002, Debin Ma 2011b).

The absence of commercial and civil codes introduced an element of uncertainty into private ownership. Private property rights in Ming-Qing China were genuine and substantive. From the official perspective, however, private ownership remained secondary to or derivative from the political standing of the property holders. Faced with the possibility, however remote, of confiscatory intervention that no legal response could remedy, property holders felt it necessary to seek shelter under an umbrella of political power (DENG Jianpeng 2006, p. 69). Despite elaborate and generally predictable informal arrangements for recording, protecting, and transferring rights over land and other tangible assets, the foundation of property rights in imperial China, particularly in the sphere of commerce, rested on politics rather than law, with implications for economic change during the $19^{\text {th }}$ century and beyond to be discussed later on

For property holders, risk reduction necessitated some accommodation with officialdom. Rich households could hope to immunize their assets from routine exactions by entering the official class through the attainment of examination degrees or the purchase of official titles. 
Lesser folk relied on collective efforts that sought to extend the elaborate network of what Andrea McElderry (1995, p. 28) describes as "fiduciary communities" within which individual operators could limit risk and transaction costs to create zones of protection from sudden and arbitrary official exactions.

Interaction among property holders' pursuit of security and officials' search for revenue led to a common pattern in which officials "granted commercial monopolies to groups of merchants in return for the delivery of supplementary taxes" and enforced the "economic principle that no one could acquire the right to do business without paying. . . tax" (Eichi Motono 2000, pp. 3-4, 64).

At the national level, the throne's relations with leading merchants, especially the beneficiaries of officially-established monopolies, presented an intricate minuet of ad hoc tax assessments, imperial confiscation and "voluntary" contributions to state coffers. ${ }^{48}$ Similar circumstances, but with lower stakes, prevailed within regional and local jurisdictions.

Such accommodations typically involved agreements between officials and commercial groups (rather than individual merchants). Groups of merchants selected leaders whose authority was recognized by both officials and fellow tradesmen. Officials expected these "head merchants" to deliver tax revenues and control the actions of their associates. In return, officials stood ready to utilize their power - either directly or by allowing authorized merchants or their agents to act as informal official deputies - to block initiatives that threatened the operations of the "legitimate" or "insider" merchants (and hence the established revenue streams). Examples abound. Ping-ti Ho observes that "the interventionist state . . . protected the vested interests of all salt merchants," that every Qing-era salt merchant "owed his position to government recognition" and that "the right to sell salt was farmed out to those merchants who were financially able to pay the salt gabelle [tax] in advance" (1954, pp. 142, 136). Observing the late $19^{\text {th }}$ century, Susan Mann finds a "familiar historical pattern ... [in which] local trade organizations began to purchase the right to collect [recently imposed] lijin taxes from their own members by ... paying tax quotas in advance" (1987, p. 111).

Such arrangements equipped mercantile groups with substantial control of their trades at least within the territories administered by cooperating officials. Mercantile groups typically allowed newcomers to enter their business provided that they observed collectively-agreed rules, which might include provisions related to currency, weights and measures, product quality, apprenticeship, wages, piece rates, and, of course, tax payments.

Mercantile leaders - the so-called "head merchants" - wielded considerable power: their special status enabled ready access to officials; they could enact and enforce rules and sanction non-conforming members with fines or even expulsion from the officially-recognized trade body - the commercial equivalent of capital punishment. Thus in the salt trade, "merchant chiefs and head merchants formed a powerful ruling clique .... . [that] exerted powerful control over distribution and sale of salt" (Ho 1954, pp. 138, 141).

\footnotetext{
${ }^{48}$ Ping-ti Ho 1954, Man Bun Kwan (2001, pp. 43-47); Michael Greenburg (1951, pp. 52, 63, 66-67) illustrate such transfers.
} 
Relationships within these networks, including within families and lineages, often took the form of patron-client ties rather than transactions among equals. David Faure quotes Prasenjit Duara's study of $20^{\text {th }}$-century North China:

In a society where neither the market nor the state fully regulated economic relationships, the individual peasant (or village household) was often dependent on a powerful local figure. . . to ensure the fulfillment of a contract, to provide access to the market. . . and to protect him from predatory local government functionaries. In return, the patron received expressions of gratitude and loyalty on which he built a stock of political capital $(1988$, p. 183)

Similarly, Mann finds that "marketers and traders unprotected by patronage or family connections were vulnerable to harassment and extortion" (1987, p. 62).

Faure goes on to observe that "Ming and Ch'ing [Qing] local as well as long-distance trade was conducted under extensive patronage networks just as rural life was" (1989/1996, p. 93). By emphasizing the ubiquity of "trading under patronage" but also observing that ". . Ming and Ch'ing markets were relatively open. . . because the patrons competed" (1989/1996, p. 95), Faure offers a bridge between competing visions that analyze economic processes during the imperial era in terms of competitive markets (e.g. Ramon Myers 1980, Myers and Yeh-chien Wang 2002) or, alternatively, in terms of rivalry among gentry and official predators for opportunities to extract resources from hapless commoners (e.g. Albert Feuerwerker 1968; Huang 1985, 1990). As we shall see, the idea that genuine, but limited or incomplete property rights lead to what might reasonably be termed a "patronage economy" makes sense not only for the Ming-Qing era, but for contemporary China as well.

\subsection{The Long-run Political Equilibrium: Stability and Dynastic Cycles}

Starting with the simplest of assumptions - the emperor rules his large domains with a non-hereditary bureaucracy selected by competitive examination, employing the land tax as the primary source of fiscal revenue - we derive implications that accurately depict major aspects of the actual Ming-Qing regime. The following observations summarize the long-run properties of both the "model" and, we believe, of the system that existed prior to the $19^{\text {th }}$-century escalation of western imperial pressure:

\subsubsection{Mutual reinforcement between ideology and incentives, between de facto and de jure political and economic power.}

The combination of status, power, and high incomes available to examination graduates, official appointees, and their families provided incumbent elites and ambitious commoners with powerful incentives to seek advancement within the imperial system by investing in Confucian education for bright sons in the hope that they might earn examination degrees. The frequency with which poor households sought schooling for sons who, while eligible to compete, had no realistic chance of achieving examination success, reflected both the practical benefit of literacy 
in a society permeated by written documents and the long-term impact of Confucian ideology, which accorded respect and status to men whose educational attainments, however modest, exceeded the local norm.

The result was a remarkable consistency of objectives, incentives, and mobility strategies across social strata. Rich and poor, elites and commoners, farmers and craftsmen, all invested in education and relied on educational attainment to promote both social standing and economic gain. In this fashion, generations of Chinese strengthened an ideology that associated leadership with educational attainment and exalted hard work and thrift as the proper route to upward mobility through training, discipline, and self-cultivation.

Recent efforts by Daron Acemoglu and others to investigate the institutional backdrop of long-term economic growth emphasize links between de jure power arising from legal provisions and other formal institutions and de facto influence attributable to custom, wealth, and other informal arrangements (Acemoglu, Johnson and Robinson 2005; Acemoglu and Robinson 2012). Imperial China displayed extreme interpenetration of formal and informal influence and power. Public office was the most important source of prestige and wealth. At the same time, money was essential to finance the long preparation needed to pass the civil service examinations: during 1834/35, 81 percent of provincial examination graduates and 93 percent of successful palace examination candidates were over 24 years of age; over half of the palace graduates and nearly 40 percent of the provincial degree-winners were over 35 years (Benjamin Elman 2000, pp. 704, 706). Ping-ti Ho notes that "the children of salt merchants probably received the best schooling in the empire," which enabled a group of fewer than 300 families to produce 139 palace degree-holders and 208 provincial examination graduates between 1646 and 1802 (1954, p. 162). This cross-fertilization of economic resources, status, and political power represented both a bulwark of stability and a formidable obstacle to reform.

\subsubsection{Stability, resilience and path dependency.}

The institutional arrangements described above demonstrated great strength, resilience, and stability throughout the Ming-Qing era, supporting the enormous expansion of territory and population depicted in Table 1 and Map 1 in an increasingly commercialized but primarily agrarian economy.

The dynastic regime demonstrated a capacity not only to withstand shocks but also to restore stability in the wake of potentially destabilizing disasters. The devastating Taiping rebellion (1850-1864), which exposed the weakness of Qing rulers, was suppressed by regional leaders who possessed the highest level Civil Service examination degrees. These men mobilized troops and funds in their home provinces and defeated the rebel armies. The victorious generals, all of whom were Han Chinese, then restored control to the throne, even though it was occupied by the non-Chinese descendants of Manchu invaders. They also contributed prominently to the Tongzhi Restoration (1861-1875), a joint Manchu-Chinese effort to restore stability and prosperity by revitalizing orthodox Confucian ideology, reconstructing the traditional low-tax fiscal regime, and restoring regular civil service examinations. 
This episode demonstrates how a common ideology and close alignment of incentives among the imperial household and overlapping bureaucratic, scholarly, commercial, and landed elites created a tight web of vested interests that, once established, proved extremely difficult to dislodge. Unfortunately, the same forces that promoted stability also militated against reforms that might threaten the standing, the incomes, or the future prospects of interlocking socioeconomic leadership groups that dominated the imperial polity.

\subsubsection{Limited monetary and financial development}

The Qing economy operated under a bimetallic copper-silver monetary standard with no regular issue of official paper currency and no long-lived government debt of other financial instruments. This arrangement, which imposed high transaction costs throughout the economy, reflected the absolute nature of political authority, which was not limited by the sort of checks and balances that gradually emerged in leading European states prior to the British industrial revolution.

The absence of checks and balances led to the ironic result that China, which pioneered the use of printed paper currency during the Song dynasty (960-1279), reverted to a system built around low-denomination copper tokens and un-coined silver because repeated episodes of official mismanagement evidently eroded the private sector's trust in government monies as a store of wealth or even as a medium of exchange for large transactions (Ma 2013).

The Qing monetary system revolved around two core elements: officially minted copper cash, often joined in "strings" of up to 1,000, mediated retail transactions, while wholesale trade and large transactions relied on a mixture of silver "shoes" (shoe-shaped ingots cast by private firms), bits of silver bullion and, as European trade expanded, an array of imported silver coins from Europe, the Americas and Japan. ${ }^{49}$ The exchange rate between copper and silver exchange, theoretically constant at 1000 standard cash per silver tael, varied widely over time, across regions, and among different trades. ${ }^{50}$

In the face of such monetary complexity, local elites, guilds and mercantile groups sought to reduce currency risk by establishing and enforcing uniform local monetary standards. These efforts, aimed at reducing transaction costs for particular groups and districts, created a maze of exchange rates linking multiple varieties of silver ingots, coins and bits, copper cash, bills issued by merchants and financiers, and bookkeeping currencies established in various localities and trades. The resulting system imposed a regime of high transaction costs resulting from unstable exchange rates, from the expense of shifting assets from one currency to another, and, for large transactions, from the need to hire specialists to mediate the fulfillment of payment obligations

\footnotetext{
${ }^{49}$ Standard works on monetary history include Eduard Kann 1975, Frank H. H. King 1965, and PENG Xinwei 1968.

${ }^{50}$ The term tael refers to traditional measures of monetary silver. The kuping tael used in Qing government accounts, for example, was a bookkeeping currency consisting of 37.5 grams of pure silver.
} 
The limited extent of property rights and the arbitrary nature of the underlying legal system seem to account for the restricted development of financial instruments. Unlike Holland or England, there was no formal market for public debt. The absence of credible financial instruments restrained state capacity and rendered the traditional state prone to fiscal predation or confiscation in times of crisis (CHEN Feng 1992, chapter 7; Ma 2013). De-facto governmental borrowing (or extraction) took the form of advance collection of taxes, forced loans from merchants, and sale of official titles and positions. Formalized public debt began only during the latter half of the $19^{\text {th }}$ century when the bargaining power of lenders (particularly Western bankers and governments) was reinforced by extraterritorial privilege or Western consular and military presence (ZHOU Yumin 2000, pp. 277-287, Ma 2013).

The absence of secure property rights and of institutional restraint on imperial power produced a domestic economy in which only land was suitable for long-term passive wealthholding. We see no emergence of tradable long-lived financial instruments, indeed no scope for financial transactions beyond spot exchanges in the absence of personal links. The general absence of impersonal financial arrangements continued well into the late $19^{\text {th }}$-century treaty port era, when "much share capital was raised through private connections" (David Faure 2006, p. 52).

\subsubsection{How the imperial system constrained growth}

Despite its formidable economic achievements, the imperial system harbored important obstacles that prevented China from moving rapidly to capitalize on new growth opportunities arising from the industrial revolution in Great Britain. Four specific items stand out:

Lack of vision. Alexander Gerschenkron emphasized the importance of ideology as a driver of industrialization in follower nations: "in a backward country the great and sudden industrialization effort calls for a New Deal in emotions" (1962, p. 25). In China, such inspiration came only in the $20^{\text {th }}$ century. Even the most progressive Qing reformers, men who supported the expansion of factories and rail transport, failed to comprehend the potential of intensive growth to raise productivity and living standards.

Lack of fiscal capacity. Dwight Perkins describes Qing public finances as "almost unbelievably weak" (1967, p. 492). Available data indicate that the share of late Qing GDP that reached government coffers was considerably less than the GDP share that Japan's contemporaneous Meiji regime devoted to economic development expenditures.

Lack of administrative structure. Modern economic growth leans heavily on the capacity of the state to formulate and implement policies that support and encourage development. Contemporary and retrospective accounts agree that such capacity was notably lacking in the Qing state, which Julia Strauss describes as a "presiding state. . . . [that] was usually content to reign and loosely regulate rather than vigorously rule" (1998, p. 12).

Patronage economy. Although private ownership figured prominently in China's imperial economy, the absence of legal protection against official abrogation of property rights obliged private owners to seek protective alliances with incumbent officials and local power- 
holders. Evidence from the $19^{\text {th }}$ and $20^{\text {th }}$ centuries demonstrates that the resulting merchantofficial combines obstructed innovation and also encouraged widespread corruption.

We now turn to the long and painful process of pushing back these barriers.

\section{TURBULENT CENTURY: CHINA CONFRONTS THE INDUSTRIAL REVOLUTION, 1840-1939}

\subsection{China's Opening, 1840-1895}

The stability of the imperial equilibrium hinged on its capacity to thwart internal and external threats. Although China's Qing rulers, leaders of a semi-nomadic group with origins along China's northeastern frontier, were unusually adept at expanding and defending China's land borders through a combination of diplomacy and force, the $19^{\text {th }}$ century brought a notable acceleration of political and economic change arising from both internal and external forces.

Beginning with the White Lotus (1796-1804), a series of domestic rebellions, culminating with the vast Taiping uprising (1851-1864), both reflected and contributed to the erosion of the Qing regime. The simultaneous upsurge of European military and diplomatic pressure along China's maritime frontier, accentuated by falling terms of trade, unfavorable weather trends and the reversal of long-standing silver inflows, inflicted further shocks. ${ }^{51}$

The challenge from Western imperialism represented a watershed in Chinese history - a novel threat unlike China's traditional nemesis of land-based invasion across her northern frontier. Europe's rising power threatened the economic, political, institutional and ideological underpinnings of the Qing empire. The turbulent period from roughly 1800 to 1949 helps to illuminate the dynamics of the Ming-Qing system, demonstrating its resilience while simultaneously revealing institutional obstacles to economic change highlighted in our political economy analysis.

Prior to 1800, European trade with China was a lopsided affair dominated by the exchange of Chinese commodity exports, notably tea and silk, for silver coin and bullion shipped from the Americas. British merchants, frustrated by the limitations of the "Canton system," which, from 1757, had restricted European trade ${ }^{52}$ to that city (now known as Guangzhou), urged London to demand wider access to the China market, initially with little success.

British and Indian traders made a commercial breakthrough by discovering a ready Chinese market for India-grown opium. Believing the ensuing shift in China's trade balance from surplus to deficit and the reversal of long-standing silver inflows were linked to rising

\footnotetext{
${ }^{51}$ Jeffrey Williamson (2011, pp. 33-34) concludes that China's external terms of trade fell by 85 percent between 1796 and 1821; David D. Zhang et al 2007 and Lillian M. Li (2007, pp. 27-30) cite evidence of low temperatures and declining rainfall; Man-houng Lin cites contemporary accounts suggesting that silver outflows during the first half of the $19^{\text {th }}$ century reduced China's stock of monetary silver by 7-19 percent (2006, pp. 83-85).

${ }^{52}$ The Canton system did not affect trade with Asian partners, which involved a number of port cities.
} 
opium imports, ${ }^{53}$ a disturbed Qing court dispatched a high official, LIN Zexu, to extirpate the Canton opium trade. When he did so, the British merchants sought London's protection from what they regarded as an illegitimate seizure of mercantile property. The result, fuelled by British visions of a vast China market, was the Opium War of 1839-1842. ${ }^{54}$ British arms forced the Qing to accept the Treaty of Nanking (1842), which ceded Hong Kong to the British, forced the Qing to accept a regime of virtual free trade, and initiated the "treaty port" system by opening five Chinese ports to British merchants. This agreement, which set the tone of China's international economic relations during the century prior to the Pacific War, subsequently expanded to include dozens of treaty ports where foreign residents were protected by extraterritoriality at the expense of Chinese sovereignty. ${ }^{55}$

While these innovations initiated a long adjustment process that eventually resulted in substantial economic advance, the initial pace of change was slow. China's response to the treaty system poses difficulties for Pomeranz' (2000) reliance on access to cheap coal and other land-intensive goods to explain Britain's unique economic success and the consequent "great divergence" between European and Asian incomes. If these were the key obstacles to Chinese economic expansion, the $19^{\text {th }}$ century treaty system, which allowed unlimited and virtually dutyfree importation of mining equipment as well as coal and other land-intensive products, along with the gradual increase in migration of Chinese farmers into the fertile and sparsely populated plains of Manchuria, should have provided a major impetus to Chinese growth. The absence of any such outcome lends credence to our view that it was ideology and institutions, rather than resource limitations that imposed binding constraints on China's growth prospects both before and after the start of the treaty port system. As we will see, the insertion of a treaty port economy in the traditional Chinese empire represented initially what seemed like a small rupture to a giant closed political system that would only grow over time to tear at the foundation of traditional China's long run political equilibrium.

\subsection{Change and Resistance to Change, 1840-1895}

\subsubsection{Political accommodation and institutional change to 1895.}

The new era marked by China's forced opening began disastrously for the Qing, which barely survived the devastating Taiping Rebellion (1850-1864). Confucian elites based in Hunan and Anhui provinces mobilized funds, assembled regional armies, and led successful campaigns to defeat the Taiping armies. As noted above, the "Tongzhi Restoration" (1861-1875) engineered a remarkable recovery through the revitalization of traditional institutions. The likin

\footnotetext{
${ }^{53}$ Recent research has questioned the link between rising opium imports and silver exports during the $19^{\text {th }}$ century, citing other potential sources for the reversal of silver imports, including the rising gold price of silver, declining domestic demand for silver, as well as a breakdown in the Spanish Peso Standard. See Man-houng Lin (2006) and Alejandra Irigoin (2009).

${ }^{54}$ Linda Cooke Johnson cites multiple descriptions of the large scale of Shanghai's domestic trade prior to the Opium War, including references to "forests of masts" and suggestions that Shanghai's trade volume surpassed London's during the 1830s (1993, pp. 175-176).

${ }^{55}$ Billy K.L. So and Ramon H. Myers (2011) examine the treaty port economy.
} 
(lijin) tax, levied on internal trade to help fund the anti-Taiping effort, developed into an important component within China's fiscal system. Along with new taxes on seaborne international trade collected by the foreign-administered Imperial Maritime Customs, an arrangement forced on the Qing by European pressure, the likin system began to restructure the Chinese fiscal regime. By 1908, the long-dominant land tax had declined to 35 percent of officially recorded revenue (Yeh-chien Wang 1973, p. 80).

The rise of commercial taxation, which became de-facto local revenue following the suppression of the Taipings, reflected a process of fiscal as well as political decentralization visible throughout Chinese history following major rebellions or invasions (ZHOU Zhenghe 2009). Aided by newly acquired fiscal resources, regional bureaucrats such as Li Hongzhang (18231901) and Zhang Zhidong (1837-1909) sponsored the Self-Strengthening movement (18601894), a program that aimed to expand Chinese military strength by developing a small number of Western-style, capital-intensive enterprises financed by the state and directed by prestigious officials with impeccable academic credentials. Although these enterprises, which included arsenals, factories, and shipyards, were fraught with inefficiency and corruption, they did record modest achievements (Ting-yee Kuo and Kwang-Ching Liu 1978). The Jiangnan Arsenal, located in Shanghai, impressed Japanese visitors in 1873. Japanese reformers initially relied on Chinese translations of European scientific treatises (Elman 2005, p. 411). China's Hanyeping steelworks began production five years ahead of Japan's Yawata complex.

Despite these innovations, traditional thinking dominated, representing, as aptly suggested by the title of Mary Wright's classic book (1962), the last stand of Chinese conservatism. In contrast to the concurrent Meiji reform in Japan, there was no effort to overhaul the regime's fundamentals. There was no modern constitution or commercial law, and no reform of the currency system. Railroads were prohibited and steamships were restricted to the Yangzi and other major rivers; (Mary Wright 1962, SUZUKI Tomō 1992). Dwight Perkins (1967) concluded that "If the imperial government of China was an obstacle to industrialization, it was more because of what it did not do than because of harmful efforts which it did undertake. . . The real problem was that although the . . government. . did take a number of positive steps they were few and feeble" (1967, pp. 491-492).

\subsubsection{Economic change and its limits: the partial unraveling of key institutions}

Expansion of China's international trade was the most obvious effect of the treaty port system, which opened a growing list of ports to European commerce while restricting Chinese tariffs to a modest 5 percent. China's Maritime Customs data show the volume of exports doubling and imports rising by 77 percent between 1870 and $1895 .{ }^{56}$

Despite its modest scale, trade gradually aligned major domestic commodity prices with international markets throughout the Pacific Basin. Loren Brandt's discovery that, starting in the

\footnotetext{
${ }^{56}$ Figures come from the Nankai quantity indexes of export and import reproduced in Liang-lin Hsiao (1974), p. 274. Wolfgang Keller, Ben Li, and Carol H. Shiue $(2010,2011,2012)$ have begun to systematically exploit the trade data covering 1860s-1949 compiled by China's Maritime Customs agency and summarized in Hsiao's volume.
} 
late 1880s, domestic prices for rice, wheat, and cotton moved in close harmony with market shifts throughout the Pacific basin demonstrates that several decades of unfettered trade forged unprecedented global links with vast swathes of China's economy $(1985,1989)$. By the late 1880s, millions of villagers inhabiting the Yangzi river's drainage area who grew, bought, or sold rice, or worked for or traded with partners who engaged in those activities, had become unwitting participants in far-flung networks of international commerce, influencing and being influenced by distant producers, consumers, and traders of rice.

The treaty system accelerated the arrival of new technologies, initially to the treaty ports themselves, which in both the $19^{\text {th }}$ and $20^{\text {th }}$ century versions of expanded links to global markets, became staging points for the domestic diffusion of technology. The development of manufacturing, however, fell far short of the potential surrounding the expanded inflow of goods, technology, and knowledge during the latter half of the $19^{\text {th }}$ century.

Attempts by Chinese and European entrepreneurs to capitalize on opportunities linked to new technologies and trade arrangements encountered powerful resistance. The barriers, which affected the expansion of railroads, inland steam shipping and other public infrastructure (Shannon Brown 1978; SUZUKI 1992), emerge from the history of private efforts to introduce new technologies and business arrangements in the processing of agricultural commodities like soybeans and silk larvae.

When Jardine, Matheson, a rich and well-connected British firm, set out to establish a steam-powered silk filature in Shanghai during the 1860s, they anticipated difficulties in installing imported machinery and training Chinese workers to operate it. What they did not expect, and what stymied this initiative, was their inability to obtain prompt and efficient delivery and storage of cocoons in the immediate rural hinterland outside treaty port:

The mandarins [officials] were bribed to oppose me, people and brokers, more or less in the hands of the silk hongs [companies] frightened from me, suitable houses were refused me or set fire to, and what I actually built was pulled down and the Chinamen that did assist me were put in chains (quoted in Shannon Brown 1979a, pp. 561-562).

Efforts to establish a steam-powered facility for processing soybeans met a similar fate (Shannon Brown 1979b). Chinese entrepreneurs fared no better: during the 1870s, riots by traditional silk weavers caused a local magistrate to order the closure of mechanized silk-reeling factories that an overseas Chinese merchant had established in Guangdong (Debin Ma 2005).

Conflicts arose when new ventures clashed with vested interests arising from restrictive coalitions of merchants who arranged informal trade monopolies by promising to deliver tax payments to official patrons (Motono 2000, pp. 3-6). Such arrangements had a long history: in Tianjin, for example,

By the early eighteenth century. . . groups of transport workers had become organized into a guild system in which groups of workers received government permission to monopolize transport in a particular area. Official notices were pasted up in each sector, delimiting its boundaries and naming the authorized transport agent. From the Kangxi to the Xuanfeng reigns (1662-1861), the Qing government issued . . . notices of official approval to the transport guilds. . . . Under the Guangxu Emperor [r. 1875-1908], successive magistrates issued 11 orders supporting the special privileges of the guilds. (Gail Hershatter 1986, p. 117). 
The resulting merchant-official combines joined forces to repel interlopers who threatened mercantile profits and official revenues. In response to complaints from merchant clients, officials either intervened directly ("the Chinamen that did assist me were put in chains. .." ) or empowered incumbent merchants and their agents to act as official deputies in restricting entry. During the 1870s, merchants from the southern city of Swatow (Shantou) controlled Shanghai's opium trade. When newcomers imported large stocks in advance of an increase in taxes, the Swatow guild obtained permission to bring in "runners" who assumed the role of policemen. These agents

attempted to collect the Lijin tax from anyone who dealt in opium, regardless of [where and by whom]. . . it was stored. Moreover, they charged . . . non-members of the Swatow ... group a higher rate than their members. Furthermore, they confiscated all opium the moment it left the foreign importers' hands ... unless the transaction was carried out by members of the group. In order to prevent commercial activities by non-members, they sent spies and informers around the shops. (Motono 2000, p. 98)

Contemporary and retrospective accounts agree that such arrangements restricted innovation. Writing in 1909, H.B. Morse noted that

all Chinese trade guilds are alike in interfering with every detail of business and demanding complete solidarity of interest in their members, and they are all alike also in that their rules are not a dead letter are actually enforced. The result is a tyranny of the many over of the individual, and a system of control which must by its nature hinder 'freedom of enterprise and independence of individual initiative' (1909/1966, p. 24).

Shannon Brown echoes this sentiment: "Caught between the guilds . . . and the officials ... the Chinese merchant was hardly in a position to play the role of . . . Schumpeterian entrepreneur" (1979b, p. 183).

As trade expanded, the treaty system itself began to undermine the merchant-official nexus that tormented would be innovators. An obscure provision of a 1858 Sino-British agreement allowed foreign merchants to avoid domestic taxes on goods in transit to or from a treaty port by paying a fixed ad valorem fee. This "transit pass" privilege, often cited to illustrate the intransigence of local Chinese officials and the limited reach of British power, ${ }^{57}$ became an unlikely catalyst for institutional change once Chinese operators recognized that transit passes intended for the use of foreign traders could shield their own goods from domestic taxation.

Chinese merchants bought transit passes from British firms, paid foreign residents to assume nominal ownership of goods in transit, and even created "pseudo-foreign" trading houses operated entirely by Chinese, who again shared the resulting savings with their passive

\footnotetext{
${ }^{57}$ Thus the historian John K. Fairbank echoed contemporary complaints to the effect that "the British were quite unable to prevent the taxation of their goods" outside the treaty ports (cited in Dong Wang 2005, p. 18).
} 
foreign partners (Yen-p'ing Hao 1986, pp. 263-267). The insightful work of Eiji Motono (2000) reveals the full impact of these initiatives, which upset a long-standing equilibrium that had preserved local monopolies, allowed local officials to share in commercial profits, and, as is evident from the examples cited above, to throttle interlopers.

Motono (2000) sees these merchant-official combines as the structural foundation of traditional Chinese merchant groups and networks. He shows how the small Western presence established a new source of power and authority in China that eroded the imperial system's monopoly over political control and undercut the authority of mercantile guilds, fracturing traditional group solidarity among members of particular trades and enhancing the property rights and security available to Chinese businesses outside the traditional patronage networks.

China's treaty port system (and China's recent "opening up" policy) richly illustrates Paul Romer's (1993) insistence that the impact of international trade resides in flows of ideas as much as in shipments of commodities. The treaty system brought new organizational forms into the treaty ports, into the domestic economy and into China's governmental machinery. Early examples include modern banks, the Shanghai stock exchange, shareholding companies with limited liability, the foreign-managed Imperial Maritime Customs, local self-government and China's new foreign ministry, the Zongli yamen. The treaty ports served as transmission belts for unfamiliar structures of knowledge and belief: engineering, medicine, international law, legal jurisprudence, political representation, Christianity, pragmatism, democracy, and Marxism, among others. XIONG Yuzhi (2011) traces the diffusion of new ideas through multiple channels. The steady trickle of new perspectives was punctuated by sharp reminders of the wide gap separating Chinese and international norms: ZHAO Jin describes the shock on Chinese sensibilities when authorities in Shanghai's International Settlement refused to halt traffic to make way for the entourage of high level Chinese officials, a common practice in imperial China (1994, p. 118).

It is easy to dismiss the $19^{\text {th }}$ century treaty port system, along with the accompanying expansion of foreign residence, trade, and investment, as too small and isolated to alter the trajectory of China's vast rural hinterland. R. H. Tawney, an eminent British historian who became interested in China, described China's treaty ports as "small islands of privilege at the seaports and on the great rivers. ... a modern fringe. . stitched along the hem of the ancient garment" (1932, p. 13). Rhoads Murphey argued that the treaty system left "the great majority of Chinese ... unaffected, directly or indirectly" and that "materially, China went on behaving for the most part as it had always done" (1977, pp. 226-227).

Despite their small size, the significance of China's $19^{\text {th }}$ century treaty ports and trade rested on their catalytic role in initiating processes of change that, while slow to develop, eventually resulted in a remarkable transformation of China's economy that continues today. Ironically, Rhoads Murphey, while insisting that treaty ports were "tiny and isolated islands in an alien Chinese sea," concluded by predicting - accurately, as subsequent events confirmed in short order - that China might "come to travel. . . along the same road which the western colonists first urged" (1977, pp. 225, 233-234). As history shows, that journey was long and complex. 


\subsection{The Shock of Defeat by Japan as a Turning Point}

Military defeat in the Sino-Japanese War of 1894-1895 by a nation long regarded as a student rather than an equal inflicted a profound shock on Chinese sensibilities. The Celestial Empire, having stumbled into the unwelcome role of global laggard, faced unprecedented mockery as the "sick man of Asia." The ignominy of Japan's victory magnified the impact of the 1896 Treaty of Shimonoseki, which granted foreigners the right to establish factories in the treaty ports, thus sparking a rapid expansion of foreign direct investment. ${ }^{58}$ Forced acceptance of foreign-owned factories indirectly legitimized Chinese modern enterprise, greatly reducing the harassment that conservatives had routinely inflicted on Chinese industrial ventures, especially those outside the protection of prominent reform leaders.

The final five years of the $19^{\text {th }}$ century saw a sudden and eruptive ideological transformation of the sort modeled by Timur Kuran (1995). Information about foreign realities and ideas, formerly confined to a narrow circle of reformers, now commanded a nationwide elite audience. HUANG Zhongxian's account of his experience as the first Qing ambassador to Meiji Japan received little notice when it first appeared in 1887; ten years later, demand soared following Japan's naval victory over Chinese forces. Huang's work joined a wave of translations, many by YAN Fu, China's foremost interpreter of Western thought, that, for example, exposed Chinese audiences to Thomas H. Huxley's social Darwinist idea that nations had to evolve, adapt and progress or face extinction. YAN's translation of Huxley's famous speech on social Darwinism went through more than 30 editions in the ten years following the initial 1898 Chinese translation (see XIONG 2011, pp.557-559). YAN's 1902 translation of The Wealth of Nations also commanded a large audience.

New thoughts sparked political and social change. Military defeat encouraged (perhaps excessively) negative evaluation of the self-strengthening effort and of China's overall backwardness (Elman 2005, pp. 379-382, 392-393). The Qingyipai, a powerful alliance of prominent conservatives who had steadfastly opposed self-strengthening initiatives suffered a rapid loss of influence amid an explosion of new civic and academic associations (JIN and LIU 2011b, pp. 64-69, 73).

China's naval defeat triggered the Hundred Days' Reform centered in the southern province of Hunan in 1898. Inspired by Japan's Meiji reforms, sponsored by influential provincial leaders and nationally-prominent intellectuals, and backed by the young Guangxu Emperor (r. 1875-1908), this effort to modernize China's politics, economy, education, and military was crushed by conservatives led by the emperor's aunt, the Dowager Empress Cixi. The conservatives subsequently condoned the Boxer rebels' xenophobic violence against Westerners and Christians, a movement which brought yet another humiliating defeat at the hands of a multi-country expeditionary force - this time including Japanese - and an exorbitant reparation extracted by the Western powers.

Elite opinion then veered toward more radical Meiji-style reforms. Even the Dowager Empress, long an implacable enemy of modernization, stepped forward as an improbable proponent of constitutional reforms that echoed the rejected 1898 initiatives (JIN and LIU $2011 \mathrm{~b}, \mathrm{pp}$. 73-76). The new reform plans were comprehensive and ambitious. They envisioned a constitutional monarchy with national, provincial and local parliaments. Military

\footnotetext{
${ }^{58}$ Foreign enterprises were only allowed to trade in the Treaty Port before the Treaty of Shimonoseki.
} 
modernization was high on the reform agenda, which sought to modernize public finance and adopt a national budget. The reformers established Ministries of Commerce (subsequently Industry, Agriculture and Commerce), Finance, Education, and Posts and Communications, encouraged the founding of local chambers of commerce, and sought to reform the currency, establish modern banks, and expand railroads and other public infrastructure (Wellington K.K. Chan 1977, chap. 8; Douglas Reynolds 1993).

New initiatives in taxation, law, and education began to erode major barriers to longterm economic development. The newly established Ministry of Commerce set out "to break the control of the Qing local governments over the Chinese merchants' groups and Chinese firms." To this end, reformers sought to eliminate tax-farming arrangements involving cooperation between "the leaders of the prominent Chinese merchants' groups and the officials of the Lijin tax bureau" (Motono 2000, pp. 154-156). The decision to abandon the thousand-year tradition of Confucian civil service examinations shook the foundation of the power structure that had long supported the patronage economy of imperial China, and paved the way for the rise of a modern schooling system.

\subsection{Economic Developments 1912-1949: Mixed Outcomes and Partial Breakthrough}

Ironically, the late-Qing reforms, which delegated greater political and fiscal authority to the provinces, contributed to the Qing dynasty's downfall in 1911, when a modest military rebellion in Wuhan (Hubei province) initiated a cascade of provincial secession. A new Republican era, inaugurated in 1912 with much fanfare and great aspirations, quickly collapsed into a welter of regional military regimes. It was not until 1927, when the Kuomintang, led by Chiang Kai-shek (Jiang Jieshi) established its new capital in Nanjing, that the Warlord Era gave way to some semblance of national governance. Ironically, it was during these decades of political instability and fragmentation that the first major wave of Chinese industrialization and economic change took off as illustrated below.

\subsubsection{Institutional restructuring and state-building in a time of instability}

While historians continue to study China's failed experiment with parliamentary government and local self-rule during the first four decades of the $20^{\text {th }}$ century, the so-called "Warlord era" that followed the Qing dynasty's 1911 collapse recalls the political fragmentation commonly observed during dynastic interregnums. One researcher counts 140 conflicts involving more than 1,300 rival militarists between 1911 and 1928 (Phil Billingsley 1988, p. 24). Through much of the 1910s and 1920s, the self-styled national government in Beijing lacked both revenue and authority. Along with the loss of the power of personnel appointment at the province and county levels, fiscal decentralization placed the Beijing administration on lifesupport from foreign loans collateralized by revenues from the Western-controlled (and efficiently managed) bureaucracies charged with collecting customs and salt taxes (Strauss 1998, Iwai 2004). 
As often witnessed in China's past, prolonged weakness at the center created opportunities for experimentation with new ideas and institutions that would later reshape the long-term trajectory of Chinese history. Despite the political chaos, the first three decades of the $20^{\text {th }}$ century brought an interlude of cultural enlightenment that Marie-Claire Bergere (1986) identified as the "golden age of the Chinese bourgeoisie." New concepts such as democracy, science, and self-government, new styles of Chinese writing, literature and academic scholarship, new generations of politicians, scholars and entrepreneurs, and new systems of education became increasingly prominent in new environment of patriotism and nationalism (Charlotte Furth 1983, Philip Kuhn 1986, Sun 1986). In the face of increasingly aggressive Western and Japanese penetration, student-led demonstrations against the 1919 Versailles Treaty $^{59}$ expanded into a broad attack on traditional culture. While some reformers railed against the inability of Confucian thinking to encompass science or democracy, others joined a 1921 Shanghai conclave that established China's Communist Party.

Both the privileges and autonomy of treaty ports, especially the largest of them, Shanghai, strengthened in this time of weakened central rule. Although tinged with foreign privilege and racial discrimination, the steadfast upholding of freedom of speech and association in the treaty ports fostered an explosive growth of chambers of commerce and associations of bankers, lawyers, and accountants, most notably in Shanghai (Xiaoqun Xu 2001). Relative peace, stability and rule of law also nurtured the first generation of Shanghai industrial tycoons, including the Rong brothers (textiles and flour milling), LIU Hongshen (matches) and the Jian brothers (tobacco), all of whom operated outside the traditional bureaucratic patronage system. The legal and jurisdictional autonomy of Shanghai's International Settlement sheltered the local branch of Bank of China from the predatory attempts of the fiscally-strapped Beijing government (Debin Ma 2011c).

The result was a unique symbiosis between Chinese entrepreneurs and foreign-controlled treaty ports that flourished despite the social discrimination that the expatriate communities inflicted on their Chinese neighbors and business partners (Parks Coble Jr. 2003). The benefits of rule of law were widely recognized; as one observer noted in 1917:

The Chinese residing in the International Settlement have numbered 800,000 . Although they are unspeakably low in knowledge and [education] level, under the influence of British custom, their habit of following the law is superior to [Chinese in] the interior. . . . [whose] officials bully the people and the people dare not resort to the law, whereas the residents in the Settlement all know that detaining people without warrant is kidnapping, and a kidnapper, whether an official or a commoner, would be punished (cited in Xu 2001, p. 41).

Nonetheless, overall political uncertainty across China in this period presented the reverse side of the North paradox: "a government too weak to be a threat ... [is also] too weak to enforce its writ and provide a stable political and legal environment" (William C. Kirby, 1995 p. 50). China's 1904 Company Law is a case in point. This measure, which introduced limited liability and aimed to provide universal and formal property rights to Chinese businesses through company registration, attracted few registrations apart from banks and other officially-

\footnotetext{
${ }^{59}$ China, which supplied over 100,000 non-combatant workers to support British and French forces in Europe, expected the Versailles settlement to include the return of German concessions in Shandong province. Instead, Article 156 of the treaty awarded these territories to Japan.
} 
backed large scale enterprises (Kirby 1995). In an environment of political uncertainty and civil unrest, formal registration was widely viewed as a dangerous recipe for public exposure of private assets. When Guangdong lineage-based firms sought Hong Kong registration under British common law, their objective was neither to secure limited liability nor to attract outside capital but rather to obtain shelter from official predation rampant in the city of Canton wracked by rebellion and revolutions (Stephanie P.Y. Chung 2010).

Most Chinese entrepreneurs operated outside the formal sphere, drawing on longstanding traditions of private contracting and social networking to help resolve issues of information asymmetry and contractual disputes. Family firms and lineage or relation-based partnerships dominated (Zelin 2009). ${ }^{60}$ The old patronage system remained much in evidence. In Tianjin, "Guild bosses. . opposed the efforts of some merchants to introduce motor vehicles. ... threatened to kill the general manager of the factory [that had purchased trucks, so that] the factory had to turn control of transport back to the guild" (Hershatter 1986, p. 134).

The establishment of the Kuomintang-led Nanjing government in 1927 marked a step to recentralize state power. The regime mounted a vigorous effort to establish administrative structures that could formulate and implement developmental policies. Julia Strauss finds that these efforts "coalesced in a number of important pockets of Republican government" (1997, p. 340). These state-building efforts drew on the model of Western-controlled Maritime Customs and Salt Inspectorate, organizations that demonstrated the potential of efficient, honest, transparent, apolitical bureaucracies led by expatriates but largely operated by Chinese personnel (Strauss 1998, chap. 3). The Ministry of Finance, setting out to emulate the Salt Inspectorate, which it absorbed in 1927/28, hired "personnel who were experienced, competent, and hard-working," often turning to "open civil service examination as the preferred method of recruitment" as "new departments and sections were created" during the 1930s (Strauss 1998, p. 187).

The Nanjing government pursued genuine tax reforms. After restoring China's tariff autonomy in 1928 (KUBO Toru 2005), the regime sought to impose standard domestic taxes in place of the likin system, which was encrusted with tax farming, extra-legal fees and ad hoc imposts (Iwai 2004, pp.381-5). At the same time, the CHIANG Kai-shek [JIANG Jieshi], the Nanjing regime's strongman, used traditional tactics to extract resources from urban businesses. CHIANG enlisted Shanghai's criminal underworld to pressure enterprises located in Shanghai's foreign-controlled concessions leading to confrontations with prominent Shanghai capitalists and eroding the rule of law within the treaty port (Coble 1986, p. xi).

\subsubsection{The onset of modern economic growth}

China's first wave of industrialization occurred amidst political uncertainty. Following the 1896 treaty settlement, activity in mining and manufacturing accelerated sharply from its tiny initial base. Output of modern industry (i.e. excluding handicrafts) showed double-digit real growth during 1912-1936 in spite of political instability and the impact of the Great Depression

\footnotetext{
${ }^{60}$ Foreign-owned treaty port firms shared the Chinese penchant for recruiting on the basis of family or regional links (T. Rawski 1969, pp. 464-465).
} 
(John K. Chang 1969). DU Xuncheng shows that nominal annual industrial investment by Chinese nationals from 1914 to 1925 was 11 times the tiny figures recorded during 1840-1911 (noted in Linsun Cheng 2003, p. 41). Factory production clustered in two regions: the lower Yangzi area, where both foreign and Chinese entrepreneurs pursued industrial ventures in and around Shanghai, and the northeast or Manchurian region, where Japanese initiatives predominated (D.K. Lieu 1936, Elizabeth B. Schumpeter 1940, Manshū kaihatsu 1964-65, Ma 2008). World War I, which weakened competitive pressure from European imports, spurred the expansion of domestic manufacturing in the absence of tariff autonomy.

As in other nations, factory production initially focused on textiles, food processing, and other consumer products. The growth of consumer industries spurred new private initiatives in machinery, chemicals, cement, mining, electricity, and metallurgy. Official efforts (including semi-official Japanese activity in Manchuria) promoted the growth of mining, metallurgy, and arms manufacture (T. Rawski 1975; 1989, chap. 2). Foreign investors dominated the early stages of China's modern industrialization, but Chinese entrepreneurs quickly came to the fore, so that Chinese-owned companies produced 73 percent of China's 1933 factory output (T. Rawski 1989, p. 74). In some sectors, the scale of operation became substantial: by 1935, textile mills in China produced 8 percent the world's cotton yarn (more than Germany, France or Italy) and 2.8 percent of global cotton piece goods (ILO 1937, vol. 1, pp. 57-58). ${ }^{61}$

China's improving economic prospects attracted trade and investment. China's foreign trade rose to a peak of more than two percent of global trade flows in the late 1920s, a level that was not regained until the 1990s (Nicholas Lardy 1994, p. 2). C.F. Remer calculated that, between 1902 and 1931, inflows of foreign direct investment grew at annual rates of 8.3, 5 and 4.3 percent in Shanghai, Manchuria and the rest of China (1968, p. 73). By 1938, China's stock of inward foreign investment amounted to US\$2.6 billion - more than any other underdeveloped region except for the Indian subcontinent and Argentina (Chi-ming Hou 1965, p. 98). Although estimates of pre-war capital flows often blur the distinction between direct and portfolio holdings, it is evident that China played a considerable role in global capital flows. The 1938 figure of US $\$ 2.6$ billion for China's stock of foreign investments amounts to 8.4 percent of worldwide stocks of outward foreign investment; China received 17.5 percent of outbound foreign direct investment in that year (Michael Twomey 2000, pp. 32, 35) compared with 2.1 percent of inward FDI in 2001 (Dirk Willem te Velde 2006, Table 2).

Domestic investment expanded rapidly. "Modern-oriented" fixed investment (calculated from domestic absorption of cement, steel, and machinery) grew at an average rate of 8.1 percent during 1903-1936, outpacing Japanese gross domestic fixed capital formation in mining, manufacturing, construction, and facilitating industries, which advanced at an annual rate of 5.0 percent. Defying the effects of the Great Depression and political tumult, economywide gross fixed investment exceeded ten percent of aggregate output during 1931-1936 (T. Rawski 1989, pp. 251, 261), with direct foreign investment contributing at least one-eighth and perhaps more. ${ }^{62}$

\footnotetext{
${ }^{61}$ Hong Kong's prominence in the textile sector during the early postwar decades followed the arrival of Shanghai textile entrepreneurs, who diverted shipments of imported equipment to Hong Kong as Communist prospects for victory in China's civil war advanced during the late 1940s.

${ }^{62}$ T. Rawski places average annual gross domestic fixed capital formation during 1931-1936 at 3 billion 1933 yuan (1989, p. 260). Remer (1968, p. 83) estimates that China's FDI stock (which he calls "business investment"), grew by US $\$ 1.43$ billion between 1914 and 1931 , or by an annual average of US $\$ 83.9$
} 
Transport development also supported economic expansion. China's growing railway network, although much smaller than India's, was particularly important. As the length of track grew from 364 kilometers in 1894 to over 21,000 by 1937, newly constructed north-south lines slashed economic distances across a landscape dominated by rivers flowing from west to east (YAN Zhongping 1955, p. 180). Completion of railway and telegraph connections linking Peking (Beijing) and the central China river port of Wuhan, for example, reduced the time needed to ship goods between these cities, sell them, and receive the proceeds from 150 to only 2-3 days (based on Whitney 1970, p. 46). Growing availability of rail transport encouraged coal mining, with the result that "falling energy costs stimulated new activity in a wide range of industries. . . [including] railway workshops [and] manufacturers of cement, textiles, flour, cigarettes, matches, chemicals" and others. Lower fuel prices also "led to the revival of native industries which had earlier languished because of the high cost of fuel" (T. Rawski 1989, pp. 224-225; Tim Wright 1984, p. 46). Railway transport also stimulated further commercialization of agriculture, raising farmers' terms of trade and boosting production of regional specialties like cotton, fruit, sesame, peanuts, and tobacco (Ernest P. Liang 1982, chap. $5)$.

One of the most sweeping transformations occurred in money and banking. China's Republican era inherited a pre-modern monetary system that mixed silver bullion, ingots and (largely) foreign silver coins, minted copper cash, and notes issued by (mainly) foreign banks and local enterprises. Weak central control encouraged a plethora of currencies, leading to over 100 different tael bookkeeping units across China (Dai 2007, pp. 58-79). During the early $20^{\text {th }}$ century, minted silver dollars, including a rising proportion of domestic coinage, gradually replaced silver taels even in rural areas. ${ }^{63}$

The simultaneous shift toward widespread use of banknotes convertible into silver on demand under China's free banking version of a silver standard delivered even larger benefits. Beginning in the early 1920s, public acceptance of banknotes issued by the Bank of China and the Bank of Communication, quasi-private Chinese institutions that benefited from the political and legal security of China's treaty ports, grew rapidly. Innovative arrangements that allowed smaller financial institutions to exchange cash and government bonds for notes issued by these two banks accelerated the economy-wide substitution of bank notes for hard currency (Debin Ma 2013). As a result, the estimated share of notes and deposits in M1 money supply rose from 22.3-34.6 percent in 1910 to a minimum of 40.4 percent in 1925 and 83.2 percent in 1936 (T. Rawski 1989, p. 157) following the Nanjing government's shift to a fiduciary currency in 1935 (Tomoko Shiroyama 2008, Brandt and Thomas Sargent). By the 1930s, the nationwide branch network of Chinese modern banks extended to over 500 localities; some banks began to experiment with loans to farmers as well as merchants and industrialists (T. Rawski 1989, pp. $136,152)$.

million, which converts to 370 million yuan or 12.3 percent of average capital formation for 1931-36. If, as seems likely, annual FDI inflows increased between 1914 and 1931, this calculation understates the share of FDI in aggregate investment. Exchange rate data from Remer (1968, p. 151) and Hsiao (1974, p. 192).

${ }^{63} \mathrm{MA}$ Junya (2008) explains how a nationwide network of native banks shifted both bills and silver dollars to take advantage of differentials in dollar-tael exchange rates linked to varying agricultural cycles, particularly between north and south China. 
These forces resulted in increased per capita output and structural changes of the sort associated with Simon Kuznets' concept of modern economic growth in two major regions: the Lower Yangzi, where private domestic and foreign investment in and around Shanghai served as the key driver (Debin Ma 2008) and the Northeast (Manchuria), where Japanese investment and eventual takeover provided key momentum (Kang Chao 1982, MIZOGUCHI Toshiyuki and UMEMURA Mataji 1988).

More controversially, T. Rawski (1989) argues that developments in industry, transport, and finance precipitated a nationwide episode of modern economic growth at the national level during the early decades of the $20^{\text {th }}$ century. His estimates of modern-sector growth resemble earlier results (e.g. Chang 1969 for modern industry). With the modern sector accounting for only 12.6 percent of GDP in 1933 (Liu and Yeh 1965, p. 89), its growth says little about changes in aggregate output. In contrast to Murphey (1977), Rawski finds that substantial spillovers from modern sector activity pushed output expansion ahead of population growth in several non-modern sectors, including the native banks (qianzhuang), handicraft textiles, traditional water transport, and, most importantly, agriculture, which occupied two-thirds of GDP.

Constrained by the unreliability of available information on acreage and yields, Rawski appeals to indirect measures of labor productivity in agriculture: wages of hired farm labor and non-farm wages available to unskilled rural migrants in male (coal mining) and female (cotton textile factories) occupations that competed for farm labor. The argument is that, with ample labor mobility and competitive labor markets, sustained increases in real wages paid to farm laborers, miners, and mill hands imply parallel increases in the marginal product of agricultural labor, and therefore in the real income of the majority of self-employed farmers who operated independently as owners or tenants (T. Rawski 1989, chap. 6). ${ }^{64}$

These achievements occurred despite the absence of a truly national government and the inability of the aspiring Nanjing regime to establish control over interior provinces or rural areas (Lloyd Eastman 1984, pp. 219, 221) or to push central revenue above 3 percent of aggregate output (T. Rawski 1989, p. 15). Growth persisted in the face of multiple shocks: the Great Depression, falling export demand, Japan's severance of Manchuria in 1932, and rapidly rising silver prices triggered by Britain's decision to go off gold and the United States Silver Purchase Act of 1934.

While debate surrounds the extent and significance of this early wave of economic expansion, there is little doubt about what followed. Japan's 1937 invasion plunged China into an eight-year abyss of warfare, followed immediately by renewed civil strife between Nationalists and Communists. These conflicts took a massive toll of both human life and physical capital. They also imposed further costs arising from rampant corruption, fiscal predation and hyperinflation. These circumstances partly accounted for the rise of a new regime that quickly who achieved historically unprecedented centralization and control under a Communist command economy.

\footnotetext{
${ }^{64}$ Brandt (1989) makes a similar case for Central and Eastern China, focusing on increasing specialization and commercialization in the farm sector, a process that he ties to growing openness to the international economy, favorable terms of trade, and spillovers from China's emergent modern/urban sector.
} 


\section{DEVELOPMENT UNDER THE PEOPLE'S REPUBLIC OF CHINA}

\subsection{Socialist Planning 1949-1976}

When MAO Zedong's victorious armies marched into Beijing, the new regime inherited a shattered economy wracked by physical destruction and extreme macroeconomic instability. But unlike Mao's vision of the new nation as a "blank sheet of paper," the intellectual and mental outlook of China in 1950 was fundamentally different from the society that British traders and diplomats had encountered a century earlier. Growing interaction with the outside world had expanded the knowledge and broadened the intellectual horizons of elites and many ordinary folk, especially in coastal regions, with communism as a radical manifestation of such new departures.

A century of change had endowed China with a considerable, albeit unevenly distributed, physical and human infrastructure in modern transportation, administration and enterprise. The National Resources Commission, "the technical and managerial agency "set up by the Nationalists that eventually employed 12,000 staffers to direct and control most of China's industries during the Sino-Japanese War of 1937-1945, earned a reputation for efficient, apolitical operation. Former staff members figured prominently in post-war economic administration in both Taiwan and the People's Republic (William C. Kirby 1990, Morris L. Bian 2005).

Reflecting Leninist theory as well as experience acquired from the administration of rural base areas during several decades of intermittent civil war (Peter Schran, 1976, Sherman Lai 2011), the Communists came to power with a disciplined party hierarchy, to which they quickly added a vertically-integrated administrative structure that, for the first time in Chinese history, penetrated to the village level. This system, fortified by patronage linked to the nomenklatura system of official appointments and the officially-controlled distribution of scarce resources under the new central plan, equipped the state with unprecedented capacity to ensure nationwide implementation of official directives without relying on the cooperation of local gentry or other independent agents. Although provincial and local leaders often adapted and distorted messages from Beijing to promote their own agendas, this new structure produced a historic expansion of state power.

The broad contours of economic change following the establishment in 1949 of the People's Republic of China (PRC) and the re-unification of China under Chinese Communist Party (CCP) rule are well understood. The new government quickly implemented an orthodox mix of fiscal and monetary policies to restore fiscal balance and quell hyper-inflation, steps that helped facilitate recovery from damage inflicted by 12 years of war and civil strife. Following violent campaigns that expropriated the assets of urban and rural elites, the latter through a land reform that redistributed approximately 40 percent of the agricultural land (Peter Schran 1969, p. 22; John Wong 1973, p. 160; Charles R. Roll 1980, chap. 4), the PRC moved to implement a socialist planning system loosely modeled after the Soviet Union, which supplied loans, technology, and advice for China's First Five-Year Plan (1953-1957).

China's plan system, like its Soviet counterpart, sought to develop and expand a selfsustaining military-industrial complex. This called for high rates of saving to finance investment skewed toward heavy industry along with an elaborate planning apparatus to capture resources and channel them into high priority investments. With most markets replaced by officially- 
mandated allocation of resources and outputs, the regime set prices to extract savings from farmers and consumers. These savings made their way to the state coffers through profit remittances of state-owned enterprises. ${ }^{65}$ In the countryside, collectivization and strict controls on personal mobility through the hukou system of residential permits facilitated resource extraction. In the cities, rationing contributed to a buildup in household savings.

Despite these similarities, Chinese planning was never as extensive as the Soviet Union's, and remained much more decentralized (Christine Wong, 1985; Chenggang Xu, 2011). In contrast to the U-form hierarchy of the Soviet Union, the Chinese economy resembled an $\mathrm{M}$ form, with a large number of relatively self-sufficient provinces and prefectures (Audrey Donnithorne, 1972; Eric Maskin, Yingyi Qian and Chenggang Xu, 2000). ${ }^{66}$

Starting in 1958, China distanced itself from Moscow's political leadership and economic strategy, as MAO Zedong sought to accelerate the pace of development by amalgamating rural households into large-scale collective units (renmin gongshe or People's Communes), and promoting rural industrialization. The communes proved to be a costly failure: poor incentives for farm households, coupled with perverse incentives that led officials to submit false reports of bumper crops and demand excessive grain procurement, as well as massive reallocation of labor from agriculture to industry inflicted an immense famine on China's peasantry that cost tens of millions of lives. ${ }^{67}$ Efforts to revive forward momentum in the early 1960 s met with some success, but the economy suffered further setbacks in the mid-1960s when a political campaign known as the "Cultural Revolution" sparked a new reversal in economic policies and incentive mechanisms.

Mixed economic outcomes characterize China's quarter-century of socialist planning under MAO and his colleagues. The plan era brought notable expansion of industrial and technological capabilities, as well as major improvements in literacy, school attendance, maternal and infant survival rates, public health, and life expectancy. Real annual GDP growth of roughly 6 percent (aggregate) and 4 percent in per capita terms ${ }^{68}$ surpassed gains in India, and other populous low-income nations, often by large margins (David Morawetz 1978).

These successes were accompanied by shortcomings and setbacks, which occurred in part because the PRC government, while eliminating some institutional barriers inherited from

\footnotetext{
${ }^{65}$ The ratio of fiscal revenue to national product, which never reached 10 percent during the Qing or Republican eras, averaged more than 25 percent between 1952 and 1977. (Compendium 2010, p. 18).

${ }^{66}$ Using terminology derived from studies of corporate structures by Alfred Chandler and others, Maskin, Qian, and Xu (2000) describe Chinese industrial structures as "M-form" - i.e. analogous to multidivisional corporations, which they contrast with "U-form" (resembling unitary corporations) structures observed in Soviet industry.

${ }^{67}$ On official incentives, see James Kai-sing Kung and Shuo Chen (2011). Discovery of new materials has tended to raise estimates of famine deaths. Work by Basil Ashton et al (1984) and PENG Xizhe (1987), based on census data, suggests excess mortality between 20-30 million. Frank Dikötter's recent review "puts the number of premature deaths at a minimum of 45 million" (2010, p. 325).

${ }^{68}$ These official figures for 1953-1978, based on what the Chinese call "comparable prices," are from China's National Bureau of Statistics (NBS 2007, p. 7). Use of 2000 prices, which avoids upward bias inherent in plan prices assigned during the 1950s, results in average annual growth of 4.4 percent for real GDP during 1952-1978 (Dwight Perkins and T. Rawski 2008, p. 839).
} 
the past, used its unprecedented administrative capacity to implement a succession of antieconomic policies, including an assault on individual and firm-level incentives, persecution of intellectuals and educators, forced collectivization of farming, a destructive regimen of local self-reliance, the diffusion of unsuitable technological innovations, and severe restriction of cross-border flows of trade, investment, people, and information. ${ }^{69}$

Under socialist planning, growth concentrated along the extensive margin, sustained only by a rising share of GDP channeled into investment. ${ }^{70}$ Although output per person increased, consumption did not. Calorie availability for China's immense rural population fell below World Bank standards for minimum subsistence during the Great Leap Forward (1958-1960) and did not regain that benchmark for two decades (T. Rawski 2007, p. 91). Millions of Chinese villagers were no better fed in the 1970s than in the 1930s (Nicholas Lardy 1983; Chris Bramall 1989). Food supply problems limited the growth of the urban population, which, measured as a percentage of the total population, scarcely increased between 1958 and 1978. ${ }^{71}$ Moreover, a substantial gap emerged between the living standards of urban and rural households ( $T$. Rawski 1982).

Long-term failure to provide an adequate food supply reflected the conflict between central planning and individual incentives endemic to socialist systems. State research institutes made significant advances in the development of high-yielding varieties, but benefits were undermined by inefficient planning and weak incentives (Lardy, 1983). ${ }^{72}$ Industrial innovation languished because the plan system's focus on physical output prompted factory leaders to focus on quantity and skimp on quality, variety, cost reduction, specialization, and customer service (Joseph S. Berliner 1976; T. Rawski, 1980). A typical report complained that First Auto Works, one of China's premier manufacturers, found its "obsolescence of equipment and models worsening day by day" following "thirty years of standing still" (LI Hong 1993, p. 83).

\subsection{The Reform Era Since the Late 1970s}

The death of MAO Zedong in 1976 marked a clear turning point. Although unified and far stronger than in 1949, China's economy was isolated, backward, and impoverished. The reform initiatives of the late 1970s arose from twin concerns about food security and the yawning gap between Chinese productivity and living standards and conditions in nearby market economies, especially Taiwan and Hong Kong. Both threatened the CCP's political legitimacy.

\footnotetext{
${ }^{69}$ The dwindling trade ratio and near-elimination of foreign investment characteristic of China during 1949-1976 represents a joint outcome of U.S.-led efforts to isolate China and China's own anti-trade policies.

${ }^{70}$ Official data show that gross capital formation absorbed 22.2-25.8 percent of GDP during 1952-1957 and 32.2-36.0 percent during 1970-1977 (NBS 2007, p. 19). See also Shigeru Ishikawa (1983).

${ }^{71}$ Official data show that urban residents comprised 16.2 percent of the national total in 1958 and 17.9 percent in 1978 (Compendium 2010, p. 6).

${ }_{72}$ As discussed below, this untapped potential, especially in major grains and cotton, likely played an important role in the acceleration of agricultural growth after 1978.
} 
After wresting political control from Mao's associates and supporters, reform elements led by DENG Xiaoping implemented changes that sought to improve economic performance without threatening the CCP-controlled political order, the rents that cemented the loyalty of China's power elite, or the central elements of the planned economy (Naughton 2008). These efforts were not without political risk in a society left cynical and demoralized following two decades of hunger and instability.

\subsubsection{The role of political change}

China's initial decade and a half of reform rested on important political changes which interacted with economic initiatives to facilitate the economy's gradual shift toward marketinfluenced outcomes.

Recognizing that improved living standards were central to re-establishing political legitimacy, China's ruling Communist party shifted its objectives toward greater emphasis on economic growth, particularly at the intensive margin, and away from the "ideological correctness" that had turned descendents of landlords, businessmen, and non-communist political leaders into pariahs and elevated "red" enthusiasm over "expertise" derived from knowledge and experience.

The CCP also revised its own internal structure to emphasize governance based on formal procedures rather than, as under MAO, the personal inclinations of top leaders. Chenggang $\mathrm{Xu}$ refers to the early years of reform as a "watershed period in which the CCP began to transform itself from a 'personality-ruled party'" into what Susan Shirk (1993) describes as "a system governed by rules, clear lines of authority, and collective decision making institutions" (2011, p. 1090). The changes included personnel policies meant to elevate objective criteria over seniority or personal ties as the chief determinants of appointments and promotions.

Elite recruitment reflected this shift, as both government and party welcomed new graduates of China's universities following the revival of merit-based admissions in 1977. Elite recruitment gradually encompassed entrepreneurs and other former pariahs: the rehabilitation of RONG Yiren, a Christian-educated entrepreneur, disgraced during the Cultural Revolution but tapped in 1978 to establish the China International Trust and Investment Corporation (CITIC), "the investment arm of the Chinese state" and eventually appointed to the ceremonial post of Vice President, epitomized this change (Economist 2005).

Of particular importance was a new system of performance evaluation for sub-national officials based on quantitative algorithms that assigned major weight to local GDP growth (Susan H. Whiting 2001). Facilitated by China's M-form hierarchy, these policies are widely viewed as having inspired tournament-like competition among county and provincial leaders, who recognized that accelerated economic growth would bring recognition and promotion, and made strenuous efforts to ramp up local economies (Hongbin Li and Li-An Zhou 2005). ${ }^{73}$

\footnotetext{
${ }^{73}$ Montinola, Qian and Weingast provide examples of such behavior (1995, p. 74).
} 
The newly evident vertical alignment of incentives spanning the CCP leadership, local and regional officials, and ordinary Chinese, most of whom stood to benefit from rapid economic growth, reduced the agency costs inherent in any system of governance in a nation of China's size and strengthened the capacity of China's government and party leaders to shape the behavior of lower-level officials assigned to implement the center's policy decisions (Naughton 2011).

Under the PRC's authoritarian political system, the Party defines policy objectives. In doing so, leaders depend on a system of policy experimentation with deep historical roots both during the pre-1949 experience in Communist-controlled base areas, and, at greater remove, during the imperial era, when local experimentation gave birth to the nationallyimplemented likin (lijin) tax on domestic trade during the second half of the $19^{\text {th }}$ century. ${ }^{74}$ Sebastian Heilmann traces Chinese Communist experimentation, particularly in the area of land policy, back to the 1930s, and identifies "experimentation under hierarchy ... the volatile yet productive combination of decentralized experimentation with ad hoc central interference, resulting in the selective integration of local experiences into national policy-making" as "the key to understanding China's policy process" (2008, p. 29).

Under this system, proponents of specific policies promote experimental implementation, typically at a sub-regional level. This structure also permits "bottom-up" experimentation by ambitious local officials aiming to attract favorable attention from their immediate superiors or higher-level officials. De-collectivization of agriculture, the first step in China's post-1978 reform program, began with local initiatives in Anhui and Sichuan provinces (Bramall 2009, pp. 337-339).

Successful trials generate information that buttresses recommendations for widespread implementation; skeptics can review such reports and inspect the trial sites. If trials fail, costs to the national economy are slight. The advantages of such experimentation depend on sufficient local autonomy, capability, and resources to allow trial implementation, critical review of initial results (notably absent from 1958 until the late 1970s), and the capacity to ensure widespread diffusion of successful initiatives (often absent during the imperial era).

The resulting initial reform tranche focused on four areas: rural liberalization, expansion of foreign trade and investment, "enlivening" state-owned enterprises, and fiscal decentralization (Carl Riskin 1987; Justin Lin, Fang Cai and Zhou Li 2006; Barry Naughton 2007).

\subsubsection{Policy initiatives during the first decade of reform}

Agriculture and the rural economy. The central feature of China's rural reform was the revival of household farming. Initially permitted as an experiment in a few poverty-stricken areas, the "Household Responsibility System" (HRS) spread rapidly as villagers "voted with their

\footnotetext{
${ }^{74}$ On policy experimentation in contemporary China, see Elizabeth J. Perry and Merle Goldman 2007 and Sebastian Heilmann and Elizabeth J. Perry 2011. On the origins, of likin, see Edwin Beal 1958, chap. 3.
} 
feet" to abandon collective agriculture in favor of the new system, which established what amounted to household tenancy, with cultivators paying fixed rents to the local government and retaining marginal earnings for themselves. Along with the HRS, the reform raised state procurement prices for grain and relaxed controls over rural markets for both products and farm inputs.

These reforms elicited an explosive response (Justin Lin 1988, 1992). Grain output rose by almost a third between 1978 and 1984; output of cash crops and farm sidelines grew even faster. Rapid productivity growth in farming freed up a large pool of labor formerly trapped in collective agriculture (T. Rawski and Robert Mead, 1998), which, combined with a growing supply of agricultural goods, rising household incomes, and expansion of markets for both inputs and outputs to spark a boom in rural industry, especially in China's coastal provinces (Chris Bramall 2009, chap. 3). Within less than fifteen years, employment in China's townshipvillage (TVE) enterprises expanded by nearly 100 million. The success of both the HRS and TVEs demonstrated the resilience of China's tradition of private contracting in an environment of vaguely defined property rights, as well as the capacity, noted by Chenggang Xu (2011) for China's administrative system and the associated patronage structures to provide a partial (and perhaps temporary) substitute for genuine rule of law.

Fiscal decentralization. China's early reforms included important fiscal changes that replaced the former system in which the center had controlled tax revenues and then assigned funds and responsibilities to lower governmental levels (tongshou-tongzhi). The new set-up divided revenue sources among various levels of government and included an array of multiyear fiscal contracts which committed lower levels of government to deliver specified revenue flows to their immediate superiors (Gabriella Montinola, Yingyi Qian, and Barry R. Weingast 1996). Combined with an ongoing decentralization of authority over economic management begun during the plan era, this gave local governments the incentive, resources, and policy tools to promote local economic growth with intensity rarely visible elsewhere. ${ }^{75}$ However, lower rates of growth and rapidly falling profitability in the state sector (Barry Naughton 2008, pp. 107-109), agency problems in the collection of central government tax revenue, and a combination of nominal tax contracting and inflation contributed to sharp erosion in central tax revenues (Christine Wong and Richard Bird 2008).

Globalization. Following a period of intense debate in which, as in late Qing, conservatives insisted that international contacts threatened to erode the cultural foundations of Chinese society (LI Lanqing 2009, ZHAO Ziyang 2009), the PRC embarked on policy of gradual opening, initially focused on the establishment of four Special Economic Zones in the southern coastal provinces of Guangdong and Fujian, along with increased autonomy for those provinces to approve foreign investments and retain foreign exchange earnings.

After an initial period of confusion, ${ }^{76}$ the new zones powered a steep increase in laborintensive manufactured exports. Guangdong and Fujian welcomed investments by overseas

\footnotetext{
${ }^{75}$ Chenggang Xu (2011, p. 1144) emphasizes the importance of local governments in China's boom, citing Pranab Bardhan and Dilip Mookherjee (2006, p. 48) who note that "China is the only country where the local governments have played a leading role in increasing rates of growth."

${ }^{76}$ Overseas Chinese visitors expressed dissatisfaction with the Xiamen SEZ during the summer of 1982, complaining that it was impossible to formulate business plans because the SEZ authorities could not specify the cost of critical elements including land, water, and electricity (1982 interview).
} 
Chinese entrepreneurs, many with local family ties, who were classified as "compatriots" (tongbao) rather than "foreign merchants" (waishang) and accorded special privileges. China benefited from a historical accident: Beijing's decision to allow inflows of foreign direct investment came just as steep increases in labor costs prompted Taiwanese and Hong Kong entrepreneurs to seek new locations for labor-intensive export operations. The resulting marriage of ethnic Chinese business operators with what soon became a tidal wave of domestic migrant workers boosted nascent reform efforts and launched China toward its current status as "workshop of the world."

Foreign direct investment focused on labor-intensive export production soon spilled beyond the zones to encompass China's rapidly expanding rural factories, first in Guangdong and Fujian, and then in other coastal provinces. When early experiments with openness delivered large benefits, regional competition sparked growing enthusiasm for expanding foreign trade and investment, with officials at every level scrambling to capture opportunities linked to growing flows of trade, inbound direct investment, and inflows of knowledge and information, both through personal interaction and via the gradual diffusion of telephone, fax, computers, and the internet.

At the same time, falling international transport costs and new computer/information technologies encouraged large multi-national manufacturers to set up far-flung supply chains to take advantage of international differences in capabilities and costs. These firms viewed China as a stable source of inexpensive and cost-effective labor; for China, the multi-nationals promised new sources of capital, managerial knowledge, market access, and technology. This confluence of interests produced first a trickle, and then a torrent of capital inflows as local governments raced to attract top international companies. Following an initial focus on export production, China's ongoing economic expansion sharpened the interest of multi-national firms in China's domestic market as well. This enabled Chinese officials to hone their strategy of offering market access in exchange for large-scale technology transfers to the foreign firms' domestic suppliers and joint venture partners.

As a result, China, formerly among the most isolated economies, moved rapidly to rejoin the global system of exchange. Between 1978 and 1993, official data show a rise in China's trade ratio from 9.7 to 31.9 percent along with rising inflows of foreign investment.

Enlivening state enterprises. Between 1955 and 1978, the number of industrial enterprises increased from 125,000 to 348,000 , output rose by a factor of 10 , and factory employment expanded from 5.9 to 61 million workers. In 1978, state-owned enterprises contributed 77.6 percent of industrial production, with the remainder coming from collective firms, most controlled by local governments or state-owned firms. ${ }^{77}$ Most firms, most managers, and many workers had no market-economy experience. Enterprises carried out instructions. Pricing, advertising, marketing, product selection, and responding to market developments played no role in day-to-day operations. Observations from 1982 regarding two manufacturers of sewing machines illustrate pre-reform circumstances. When a Chinese visitor suggested that the work force at a Guangzhou factory was three times the necessary size, the manger agreed, but asked "if we did not employ them, where would they go?" The manager of a large Shanghai plant insisted that he did not know the unit cost of the products coming off

\footnotetext{
${ }^{77}$ Data in this paragraph are from Nai-ruenn Chen (1967, pp. 182, 475); Industry 2000, p. 21; Compendium 2010, p. 40; Yearbook (1991, p. 96).
} 
his assembly line, telling visitors that "our job is to produce sewing machines; costs are the concern of the general company office" (1982 interviews).

China's reformers, dissatisfied with the passivity of firms that were intended to lead China's economy, set out to "enliven" state-owned industry by injecting new incentives, flexibility, and technology. ${ }^{78}$ Neither privatization nor bankruptcy was considered. Instead, managers of state enterprises were granted modestly expanded autonomy. Funding was shifted from government grants to loans from newly established state banks. Hints of a labor market began to appear: retirees and workers with special skills concluded informal moonlighting arrangements. A new class of "contract" workers emerged without the lifetime job security promised to incumbent workers in state-owned enterprises.

Rather than transferring profits (and losses) to the state, firms could now keep a share of their profits and deploy them to upgrade equipment, pay bonuses or improve workers' housing. To supply nascent markets, firms were allowed to find their own outlets for production that exceeded plan quotas, which in China tended to be considerably below actual capacity. In 1984, a new "dual track policy" institutionalized these initiatives, partitioning most commodity markets into plan and market components. This horizontal bifurcation represents a genuine policy innovation, retaining the tax/subsidy elements implicit in plan allocations of inputs and outputs while revealing current information about marginal costs to agents throughout the economy. ${ }^{79}$

\subsubsection{Assessment of the first decade and a half of reform}

Despite obvious limitations, China's initial reforms -economic as well as political represent a watershed in Chinese economic history. For the first time, China's economy avoided most of the Qing-era institutional constraints as well as the most restrictive of the fresh obstacles imposed by the PRC. With the environment of the 1980s and early 1990s still far from ideal, and powerful restraints still limiting both domestic markets and global participation, the scale of the response to new opportunities, which astonished both domestic and overseas observers, attests to the underlying potential of capabilities and behavior patterns inherited from the decades and centuries prior to 1949 as well as the scale of human and physical capital accumulation under the PRC.

The greatest success occurred in the countryside, where the explosive response to the household responsibility system banished the specter of hunger and sparked the largest episode of poverty alleviation in human history (Martin Ravallion and Shaohua Chen 2007; T. Rawski 2011 b). China's rural economic revival went far beyond an intensification of individual effort. The reform unleashed a torrent of entrepreneurship replete with written contracts, formation of supply chains and market networks, circumvention of official restrictions, bribery, and

\footnotetext{
${ }^{78}$ Accounts of initial reforms affecting state-owned industry include Barry Naughton (1995) and Edward Steinfeld (1998).

${ }^{79}$ Under modest assumptions, this regime approaches Paul Samuelson's vision of a market system with initial lump-sum transfers.
} 
profiteering. This dramatic upsurge of commerce highlighted the persistence of petty capitalist behavior that official regulations and campaigns had denounced, restricted and often punished during China's twenty years of rural collectivization. ${ }^{80}$

Similar phenomena appeared in the cities. Dwight Perkins observed that "when China stopped suppressing such activity .... Shops, restaurants and many other service units popped up everywhere. . . [because] Chinese ... had not forgotten to trade or run a small business" (1995, p. 231). This sudden reappearance of an extensive entrepreneurial repertoire following a lengthy hiatus signals the importance of human capital legacies and underlines the persistence of "stock[s] of knowledge transmitted from generation to generation" including "practical knowledge, or 'knowing how' ... . [leading to] shared behavioral regularities or shared routines within a population" (Chris Mantzavinos, Douglass North and Syed Shariq 2004, p. 77).

Rapid expansion of international trade and investment eliminated long-standing shortages of foreign exchange, began to tap the wealth and expertise of Overseas Chinese and of multinational corporations, and introduced a long-absent element of economic rationality into investment policies by channeling resources into labor-intensive export production.

Efforts to upgrade state enterprises were less successful. Losses mounted despite massive direct and indirect subsidies. Throughout much of the 1980s, China's economy was a halfway house combining elements of old and new. While the plan system, the state sector, and the official allocation of labor and capital remained much in evidence, the reform policies of agricultural liberalization, domestic market expansion, international opening, and fiscal decentralization accelerated growth, expedited the acquisition of new knowledge, and propelled a substantial injection of market forces along various margins.

Although the reform process spawned episodes of social unrest - the 1989 Tian'anmen protests in part reflected public anger over inflation and corruption and in part divisions within the leadership - several features acted to limit social friction. The first fifteen years of reform produced no substantial group of losers - a rare outcome in episodes of substantial socioeconomic change (Lawrence J. Lau, Yingyi Qian, and Gerard Roland, 2001). Income inequality retreated during the first reform decade, as rural reform success eroded the gap between rural and (much higher) urban incomes (Ravallion and Chen 2007). The early reforms mainly affected resource flows: adjustments of stocks in the form of layoffs, bankruptcy, or privatization were notably absent.

Reforms such as the dual-track system, which protected the nominal value of longstanding economic rents, stand out in this regard. In addition, potential reform losers often became its strongest advocates and beneficiaries. Dissolution of collective farming undermined the power and perquisites of rural leaders, but simultaneously endowed them with new opportunities to turn political networks into economic assets by forming new businesses or taking over former commune and brigade enterprises. Similarly, the retreat from planning encouraged widespread commercialization of government agencies, partly in response to the fiscal squeeze described earlier, which enabled government officials to turn what began as a reduction in their authority into economic gain.

\footnotetext{
${ }^{80}$ Typical descriptions include Anita Chan, Richard Madsen and Jonathan Unger (1992, pp. 271-282) and Thomas Lyons and Victor Nee (1994).
} 
Of equal or perhaps greater importance in preserving stability was massive resource redistribution from China's rapidly growing and dynamic non-state sector to the sluggish state sector. Wages and employment in the lagging state sector continued to grow because of ongoing injections of credit through China's state controlled financial system. Limited channels for deploying China's rapidly rising savings-a product of financial repression-meant that much of the increase in savings ended up in China's state-run banks, which in turn recycled them to state-linked firms and institutions. These flows, which exceeded $10 \%$ of GDP by the late 1980s/early 1990s, ensured that the gains from rapid growth were more widely shared than would otherwise have occurred (Brandt and Xiaodong Zhu, 2000).

\subsubsection{Political and economic change since the mid-1990s}

Despite more than a decade of rapid economic expansion, China reached a critical crossroads during the early 1990s. Growth had become increasingly cyclical, with successive periods of liberalization and reform accompanied by rising inflation along with accelerating growth. Soft budget constraints in the state sector saddled the state-owned banks with nonperforming loans that may have exceeded one-half of their asset portfolios (Brandt and Zhu, 2006). Central government fiscal revenue fell to twenty percent of the total, and only 3 percent of GDP. In various ways, these problems reflected one central issue: the drag on an increasingly liberalized economy arising from bloated, plodding, and inefficient state-owned enterprises burdened with surplus workers, weak management, lax labor and financial discipline, rising losses, and overdue debts.

Urban unrest culminating in the June 1989 crackdown in Beijing and other cities, combined with the subsequent fall of the Berlin Wall and collapse of the Soviet Union confronted China's leaders with a profound crisis of legitimacy. Following initial moves to roll back previous reform efforts, DENG Xiaoping's Southern Tour of 1992 revived the momentum of market-leaning reform, paving the way for the CCP's 1993 decision to adopt the long-term objective of building a "socialist market economy." This surprisingly explicit document proposed to limit government's economic role to macroeconomic control; prudential regulation of such matters as competition, social safety nets, health and environment; and strategic planning, with other choices to reflect the outcome of market processes. ${ }^{81}$ The 1993 decision led to succession of fresh reform initiatives, including

A sweeping fiscal overhaul that sharply increased the center's fiscal strength (Wong and Bird 2008).

Comprehensive restructuring of the enterprise sector, including the furloughing and eventual dismissal of tens of million redundant state sector employees, substantial privatization of both state and collective enterprises, along with further reforms - including virtual

\footnotetext{
${ }^{81}$ The text of this decision is available at http://www.gov.cn/gongbao/shuju/1993/gwyb199328.pdf, pp. 1286-1303 (Chinese version) and China Daily, Supplement, November 17, 1993 (English translation). Yingyi Qian and Jinglian Wu explain the background and impact of this document (2003, pp. 35-42).
} 
elimination of planned allocation of materials - that sharply increased the market orientation of the remaining government-linked firms. ${ }^{82}$

Financial reorganization that tightened central control, strengthened the central bank, injected new assets and removed non-performing loans from the balance sheets of stateowned banks, increased the banks' commercial orientation, and reduced the power of provincial and local officials to influence lending decisions (Franklin Allen, Jun Qian, and Meijun Qian 2008; Gang Yi 2010).

Broad embrace of globalization that transformed China into a major participant in global flows of commodities, capital, and technology (Lee Branstetter and Nicholas R. Lardy 2008). To this end, China reduced tariffs and other trade barriers in advance of its 2001 entry into the World Trade organization, established numerous economic zones and industrial parks to attract overseas and domestic investors, loosened restrictions on overseas travel and study for its own citizens, encouraged Chinese firms to invest overseas, and extended legal, tax, and regulatory changes initially restricted to special economic zones and coastal regions throughout the domestic economy.

Major efforts to expand domestic market orientation, including extensive privatization and deregulation of domestic trade and transportation, a major rollback of official involvement in pricing and allocation of both commodities and labor, and a rapid increase in the share of private business in output and especially employment, backed by new constitutional and legal provisions affirming the legitimacy of private ownership and the state's responsibility to protect private (along with state and collective) property.

The new reform efforts were far more systematic than earlier initiatives. They were also far more aggressive, including measures that imposed substantial costs on large and potentially powerful groups, such as urban state sector workers and state enterprises inundated with competition from imports following steep reductions in trade barriers. They also appear to have had the desired effects. Productivity growth in the state non-agricultural sector during 19982007 was as high as that in the non-state sector (Brandt and Zhu, 2010). Analysis of enterpriselevel TFP results shows steep improvement in state-sector performance. In 1998, the average gap between TFP levels in state-owned and (more productive) non-state firms in 425 manufacturing subsectors was more than 40 percent. By 2007, this gap had largely disappeared. (Brandt, Johannes Van Biesebroeck, Wenkui Zhang and Yifan Zhang, in progress). Aggregate TFP growth during 1998-2007 surpassed growth rates during the two preceding decades (Xiaodong Zhu, 2012).

What allowed these new reforms to go forward? Interpretations differ, but several are prominent. First, reform success persuaded growing numbers of policy-makers to move beyond the 1980s slogan of "planned economy as the mainstream, with market allocation as a supplement" (jihuajingji wei zhu, shichang tiaojie wei fu). Yingyi Qian (2000) emphasizes the accumulation of experience among China's leaders, who absorbed the lessons of China's initial reforms, studied international transition outcomes, and used the resulting knowledge to inform the evolution of Chinese policy. Rapid improvement in the quality and penetration of economic

\footnotetext{
${ }^{82}$ On labor issues, see T. Rawski 2006 and Fang Cai 2010. On state enterprise reform, see Carsten A. Holz 2003; Ross Garnaut et al 2005; Shahid Yusuf, Kaoru Nabeshima and Dwight H. Perkins 2006.
} 
research, bolstered by the arrival of graduates trained at leading overseas institutions, may have encouraged policy-makers to address long-standing problems such as the costly conflict between decentralization and supporting a large and diverse population of state-owned enterprises.

While recognizing the importance of this learning process, the expansion of reform likely built on important political shifts. Barry Naughton (2008) emphasizes the effect of personnel changes among China's top leadership. During the 1980s and early 1990s, party elders and retired officials retained the capacity to block measures that threatened specific interest groups - for example, workers in state-owned firms. Beginning in the mid-1990s, the death and decline of these "veto players" empowered JIANG Zemin, ZHU Rongji and their successors to undertake far-reaching moves that were formerly beyond the reach even of China's highest officials.

Several additional factors may have reinforced this trend. Educational disruption during the Cultural Revolution decade (1966-1976) provided reformers with an acceptable rationale for discarding seniority-based promotion in favor of personnel "quality" (suzhi), for which the metric is university or post-graduate training. The result - leapfrogging a generation of potential leaders whose main qualification was loyalty to the CCP and to MAO Zedong - surely accelerated the pace of market-oriented reform. Strong emphasis on educational attainment in recruiting for official positions and Party membership may have reduced the commitment of policy elites to planning and state ownership. ${ }^{83}$ Migration of policy-makers and administrators from dynamic coastal jurisdictions to interior regions eager to replicate the economic gains of places like Shenzhen and Shanghai may have homogenized views within the policy community. Additionally, promotion of some of the same individuals to even higher positions in both the CCP and government helped to further reinforce these trends.

\section{CONCLUSION}

\subsection{China's Economic Achievement}

In 1800, China was the world's largest national economy by the sheer weight of her population. Over the next 175 years, China's relative position suffered a long decline due to her failure to ride the waves of industrialization that swept the world. During the 1960s and 1970s, most Chinese had inadequate diets and no savings. Three and a half decades of reform have produced a genuine leap forward in the size of China's economy and the prosperity of its citizens. The recent boom has reshaped China's economic structure, sharply lowering the importance of agriculture in production and especially employment, raising the share of industry and, more recently, of services, and beginning a protracted process of urbanization. Chinese producers and consumers are increasingly engaged with sophisticated technologies like smart phones and high-speed trains. Formerly state-controlled and internationally isolated, China's

\footnotetext{
${ }^{83}$ Emphasis on educational credentials has created a strong demand for both full- and part-time training programs, as well as a lively market for forged credentials.
} 
economy once again reflects the deep and expanding influence of domestic and global market forces.

\subsection{Linking China's Economy with the Past: Continuities and Departures}

China's growth spurt has stimulated efforts to define a "Chinese model" of growth or to establish a "Beijing consensus" of development-enhancing policies (e.g. S. Philip Hsu, Yu-Shan Wang and Suisheng Zhao, 2011). Such thinking assumes that China's economic, political, and social circumstances sufficiently resemble prevailing conditions in other low-income nations so that application of Chinese policies may produce something akin to recent Chinese outcomes. But the deep historical roots surrounding important features of China's current institutions and the central role of China's unusual legacy of human capital undermine this approach.

We attribute China's recent economic success to a combination of beneficial historic legacies, recent and past accumulations of capital, skill, and policy expertise, and important economic and political changes that facilitated the realization of old and new potentials. Despite the success of China's imperial system in absorbing vast population increases, the administrative, organizational, and entrepreneurial skills, commercial and transport networks and other developmentally-promising resources visible in the Qing economy proved incapable of generating a rapid and effective response to new opportunities arising from the British industrial revolution. If historic accumulation of resources and capabilities deserves recognition as an important contributor to China's recent growth, why does China's boom begin only in the late 1970s?

To understand the long delay in China's response to the new landscape of modern economic growth that unfolded during the $19^{\text {th }}$ and $20^{\text {th }}$ centuries, this essay has focused on ideology and institutional constraints. We view the trajectory of China's $20^{\text {th }}$ century economy as a gradual and ongoing process of rolling back old and new institutional barriers obstructing prosperity and growth. We begin by comparing the Qing imperial regime with the reform-era People's Republic.

\subsubsection{Major institutional continuities}

Our review reveals substantial areas of institutional continuity linking China's past and present.

Authoritarian system. Major elements of institutional continuity begin with China's authoritarian political system. In the People's Republic, as under Qing rule, self-perpetuating elites exercise supreme authority with no formal checks and balances. Although the Qing memorial system and the Communist Party's practice of democratic centralism provide avenues for lower ranking individuals to influence policy outcomes, decisions emanating from the throne or politburo are final. Despite the growing influence of international norms and practices, China's tradition of strong official control over the administration of law and justice remains 
intact. Today, as in the past, political leaders are free to decide matters that, in other societies, might be determined by legal codes or judicial verdicts.

Personnel, agency and central-local tensions. To implement central policies, both the Qing and the People's Republic rely on centrally-managed, merit-based personnel systems. The Confucian approach emphasizing "rule of (properly trained, selected and motivated) men" rather than "rule of law" prevails. Both systems rely on a combination of ideology and oversight to limit the inevitable agency costs associated with granting substantial autonomy to lower-level officials, whose career prospects depend more on outcomes than on adherence to carefully prescribed procedures.

With imperfect monitoring, we observe similar agency problems today as under the Qing. Both regimes implement vigorous measures to curb what the center views as corrupt diversion of tax payments intended for the central treasury. The reform efforts of the Yongzheng emperor (r. 1678-1735) failed to dent "informal networks of local power and influence" or to eliminate "the tax evasion and tax farming that [had] decreased the level of remittances" to the central treasury (Zelin 1984, p. 307). These tensions persist: Vivienne Shue observes that rural administration in the PRC both before and after the start of reform "perpetuated the contained but unrelenting central-local struggle characteristic of imperial politics" (1988, p. 114). Local governments continue to resist Beijing's efforts to limit the scale of taxation and fee collection. When the center eliminated agricultural taxes and rural school fees, local leaders turned the power of eminent domain into a new source of revenue by commandeering farmland with nominal compensation and reselling it for business use at much higher prices.

Economic decentralization and local experimentation. Both Qing and the People's Republic combine centralization of political authority with relatively decentralized economies. The Qing economy was a de-facto market system with private ownership. During the prereform decades under the People's Republic, China's planned economy, though patterned after the Soviet example, was far less centralized than the USSR's, with provincial and local governments controlling numerous state-owned enterprises and managing substantial resource flows. Reforms have increased these decentralizing tendencies, albeit within the context of a largely market economy in which the state sector generates less than 30 percent of GDP (Brandt and Zhu 2010).

Chinese governments consistently preface major policy initiatives with local experiments, which form "an essential part of the central decision-making process" in China today (Xu 2011, p. 1079). Experimentation continues: in October 2011, four sub-national jurisdictions were authorized to issue provincial or municipal bonds (http://english.caijing.com.cn/2011-1025/110916003.html).

Education, human capital and entrepreneurship. The historical legacy of national civil-service examinations designed to support the imperial administration helped to make pursuit of education a hallmark of Chinese society throughout the past millennium. It also promoted remarkable cultural homogeneity across China's vast landscape. Even though PRC emphasis on basic education has delivered notable improvements in school attendance and other dimensions of human development, stocks of human capital accumulated before 1949 figured prominently in recent economic gains. Reflecting long-standing cultural values, three 
decades of negative financial returns for graduates, ${ }^{84}$ school closures and suspension of meritbased admissions during the Cultural Revolution (roughly 1966-1976), and persecution of intellectuals did not deter millions of Chinese families from emphasizing learning and study. Restoration of university entrance examinations in 1977 attracted swarms of self-taught candidates.

The legacy of human capital extends beyond reverence for education. The room allowed for small private plots and rural markets under collective agriculture helped to preserve commercial instincts in the Chinese countryside, which in turn contributed to the boom that followed the restoration of household farming. Rapid expansion of production, employment, and exports in millions of "township and village enterprises" relied on China's deep reserves of rural management capability, highlighting what Tim Wright has termed China's historic "abundance of small-time entrepreneurs" (1984, p. 325).

Alignment of Incentives. The Qing achieved considerable success in aligning incentives among the throne, the bureaucracy, the gentry, and the citizenry - all of whom sought prosperity and stability. The plan era, during which the state called on ordinary Chinese to suppress their desire for better living standards for the sake of "building socialism," emerges as a historical anomaly. Following the death of MAO Zedong, reform policies restored the traditional unity of objectives, with leaders, officials, and populace all pursuing, this time not just economic security, but also growth.

Patronage economy and income inequality. Today, as in imperial times, the absence of legal checks on official power and the consequent uncertainty surrounding property rights compels individuals and businesses to seek the patronage of powerful individuals or agencies, typically by offering gifts, services or cash in exchange for enhanced security and preferential treatment. In both systems, protection seekers devote substantial resources to constructing alliances with incumbent power-holders, promising young officials, or well-connected individuals. ${ }^{85}$ There is also a "top down" element in which official policy nurtures and protects flows of rents that strengthen the adherence of elite beneficiaries to existing power structures. Insiders at every level reap large benefits: a typical account describes an urban housing official whose family accumulated "as many as 31 houses" (AN Baijie 2013). In this case, as in Philip Kuhn's account of an episode from the 1840s, the miscreants "operated their business right out of government offices" (2002, p. 90).

Once in place, these patronage structures are self-reinforcing and therefore extremely difficult to dislodge. Just as the Kangxi emperor failed to overcome gentry resistance to a nationwide cadastral survey, recent efforts by China's current leaders "to narrow the vast gap between China's rich and poor" have foundered after encountering "formidable opponents" in the shape of "hugely profitable state-owned companies" that fiercely resist proposals to limit

\footnotetext{
${ }^{84}$ According to HOU Fengyun, "large-scale wage reductions for high-level mental workers" occurred in 1957, 1959, and 1961, and "mental workers. . were mostly excluded" from wage increases in 1959, 1961, 1963 and 1971. Hou describes 1976-1990 as an era of "no payoff to education." Apparently referring to the late 1980s, Hou notes that average monthly pay in universities was RMB57 less than in the food and drink sector (1999, pp. 181-185).

${ }^{85}$ Recent revelations about the family finances of prominent PRC officials echo historical accounts, for example in GAO Yang's biography of the 19 1 -century scholar-official HU Guangying (1993).
} 
salaries, reduce their market power, or increase their contributions to state coffers (Bob Davis 2012).

These structures contribute to high and rising levels of income inequality. Working with data from the widely studied China Household Income Project (CHIP) survey, Terry Sicular (2011) shows China's Gini coefficient for household income distribution rising from 0.40 in 1988 - no different from its estimated value during the 1930s (Loren Brandt and Barbara Sands 2002, p. 205) - to 0.47 in 1995 and 2002 and then to 0.50 in 2007, with households in the top decile receiving 34.5 percent of 2007 incomes. Since the CHIP data appear to exclude the highest income earners and are unlikely to incorporate "hidden income," which Xiaolu Wang and Wing Thye Woo (2011, Table 7) place at approximately two-thirds of the conventionally reported total for 2008, a full accounting would surely push the Gini coefficient well above 0.50 , placing China's income distribution among the world's most unequal. Since Wang and Woo find that inclusion of "hidden incomes" more than triples the earnings of households in the highest income group, (2011, Table 6), it seems entirely possible that the share of top earners in China today matches or even exceeds comparable outcomes of gentry elites during the 1880s, when Chung-li Chang (ZHANG Zhongli) estimates that 2 percent of the population received 24 percent of overall income (1962, p. 327).

\subsubsection{Key institutional departures under the PRC}

Vision/objectives. Like many of their British contemporaries (Deirdre McCloskey 2010, chap. 10), China's Qing emperors failed to recognize the enormous potential returns associated with the Industrial Revolution. But even if the Qing had grasped the long-term prospects arising from steam engines, railways, and other new technologies, concerns that unleashing such forces might disrupt the delicate balance of power and alignment of interests that supported their continued rulership might have discouraged them from pursuing of new economic opportunities.

Mao's China created a military-industrial complex strong enough to resist external military threats, completing a century-long effort that originated with the Qing selfstrengthening movement. This achievement, however, imposed huge costs on China's people. DENG Xiaoping's famous observations that "to get rich is glorious" and "it does not matter if a cat is black or white as long as it catches mice," summarized his determination to harness Chinese energies to elevate living standards as well as national strength. This expansion of national goals motivated pragmatic policies of economic opening and expansion to generate economic growth, which, under China's post-1978 reform administration, was "seen as a life and death matter for the regime" (Xu 2011, p. 1088). Indeed, the capacity to deliver economic growth and high living standards has become a key source of legitimacy for Communist rule in the reform era.

Elite recruitment and absorption of newly emerging interests. During the MingQing era, elite status derived from examination success, which required candidates and their families to undertake prolonged educational investments. Qing gentry resisted efforts to open the door to newcomers whose non-traditional mobility paths threatened to devalue traditional 
Confucian education (Carl Mosk 2010). They did so with good reason, as the abolition of the traditional examination system (1905) and the collapse of the Qing dynasty (1911) produced a rapid decline in the financial payoff to Confucian learning. By the late 1920s, the returns to "modern" education had far surpassed the financial benefit from Confucian learning among employees of the Tianjin-Pukou railway (Noam Yuchtman, 2010).

Following the MAO years, which enforced even stricter ideological limits on its political elites and actively persecuted excluded groups, the reform-era PRC has broadened elite recruitment to include two major channels - education and wealth. Along with globalization, urbanization and industrialization, opportunities for economic gains have greatly widened, absorbing potential regime opponents into elite ranks (Bruce Dickson 2008) and assisting official efforts to marginalize dissident groups.

State capacity. Building on experience accumulated in the administration of isolated rural areas during China's protracted civil war and in the civil war itself, the PRC demonstrated unprecedented capacity to formulate, implement, and monitor nationwide policy initiatives that, for the first time in Chinese history, penetrated directly to the village level. Campaigns to expand school attendance, reduce infant mortality, attack "rightists" and force villagers into collectives demonstrated the reach of these new mechanisms. Following the post-1978 restoration of individual incentives and the associated shift toward more market-oriented policies, often built upon local experimentation, these structures enabled a scaling up of efforts that were essential to delivering economic growth.

Enhanced capabilities have endowed the state with unprecedented leverage over resources. Vast foreign exchange reserves, official control over the financial system, sweeping privatization of urban housing and of state-owned and TVE assets, and widespread confiscation and reassignment of farmland all illustrate newfound state power, often exercised through local government agencies, to accumulate and allocate assets on an immense scale, partly to promote growth and efficiency, but at times in ways that widen inequality or even retard economic development.

Globalization. Foreign military power compelled the partial opening of China's $19^{\text {th }}$ century economy. Qing elites sought to limit foreign activity; individual foreigners, as well as their products and technologies, faced powerful informal opposition by local gentry. China's initial reform policies resembled those of their Qing predecessors, confining foreign commerce to a few localities. But over time, Chinese reform deepened, leading to the gradual dismantling of the fundamental institutional structure of the planned economy. The prolonged era of peace and order in the last few decades - a sharp contrast with China's Republican era (1912-1949) marked by two world wars, Japanese aggression and protracted civil strife - provided time and space for gradual reform. The peaceful and prosperous rise of Japan and several smaller East Asian economies offered powerful models of export-oriented success. Following their lead, China's reforms have moved the PRC from extreme isolation to global engagement, achieving trade ratios that dwarf those of other major economies, ${ }^{86}$ absorbing large inflows of foreign

\footnotetext{
${ }^{86}$ Official data for 2009-2011 show annual trade ratios of 44.2, 50.2 and 50.0 percent (Yearbook 2012, pp. 44,234$)$.
} 
investment, and, most recently, emerging as a substantial originator of outbound foreign direct investment. ${ }^{87}$

\subsection{Unfinished business, uncertain prospects}

As China's long boom approaches the end of its fourth decade, a new leadership group will inherit a powerful yet deeply flawed economy. Despite nagging questions about the reliability of official data, the reality of immense growth and dynamism is beyond doubt. At the macro level, academic studies identify productivity growth as the source of more than threefourths of China's reform-era increase in per capita output (Xiaodong Zhu 2012, Table 1); at the micro level, leading international firms in a growing range of industries find themselves facing intense pressure from rising Chinese competitors.

Amidst its unprecedented growth spurt, China's economy remains hugely inefficient. Improved performance among state firms has not closed the huge gap in the returns to capital favoring the non-state sectors (Brandt and Zhu, 2010). Even in manufacturing, the leading source of rising productivity, Chang-tai Hsieh and Peter Klenow (2009) find enormous inefficiency persists in the allocation of labor and capital between firms within narrowly-defined sub-sectors (see also Brandt, Johannes Van Biesebroeck and Yifan Zhang, 2012). Large-scale misallocation arises from systematic policy distortions favoring state-connected entities and urban residents, the survival of plan remnants in an increasingly marketized economy, and persistent adherence to widely discredited industrial policies. Perhaps the central source of inefficiency is a political system that uses control over resources, especially land and credit, to maintain patronage networks and mobilize support for aspiring leaders. A central aspect of these inefficiencies is the redistribution of income and assets (land, urban housing, and market power) to regime insiders, often at the expense of the economy's most dynamic sectors.

Widespread agreement about the strengths and weaknesses of the present system conceals divergent expectations about China's economic prospects. Assuming domestic political stability and continued access to overseas markets, Dwight Perkins and Thomas Rawski (2008) anticipate that China can maintain real annual growth in the 6-8 percent range to 2025. Others question the assumption of political stability. Citing evidence of corruption, predation, and rent seeking, Minxin Pei argues that "the economic costs of ensuring the CCP's political monopoly. . . though hidden, are real, substantial, and growing. ...," leading to "a set of selfdestructive dynamics" that endanger China's "most vital political institutions" (2006, p. 206).

Major developments of past two decades lend credence to Pei's concerns. The reform push of the mid-1990s, while certainly increasing the grip of market forces, also delivered a dramatic increase in the central government's control over fiscal and financial resources.

Efforts to centralize fiscal and administrative powers have coincided with changes in leadership thinking that have diminished core or "commanding heights" that the CCP sees as

\footnotetext{
${ }^{87}$ In 2011, China's outbound overseas direct investment reached $\$ 74.6$ billion, while incoming FDI amounted to $\$ 116.0$ billion (Yearbook 2012, pp. 258, 261).
} 
essential to maintaining control and therefore reserves for state-owned enterprises answerable to top leaders. The CCP initiated China's reform process by relinquishing tight control over farming. As the reforms unfolded, a succession of policy changes punctuated the steady contraction of this core - the sectors and firms that populate what Margaret Pearson (2011, pp. 28-35) describes as the "top tier" of China's economy: termination of the material allocation system, the transformation of numerous industrial ministries into trade associations, the granting of import-export licenses to thousands of companies, and so on. The list of sectors and activities cut off from state support and generally expected to fend for themselves amid market competition - Pearson's "bottom tier" - now extends to large segments of foreign trade, construction, domestic commerce, manufacturing, road transport, and urban housing, as well as most of the urban labor force.

This combination of centralizing reforms and streamlining the state-controlled core has concentrated massive power and wealth in the hands of the top leadership and the government and party personnel who manage the official hierarchy and operate China's 100-odd centrallycontrolled state enterprises. ${ }^{88}$ Without transparency or oversight, the vast resources held by small elite group that is partly hereditary, tightly networked and intensely factionalized invites malfeasance in pursuit of personal gain or political advantage.

Beijing's tight control over domestic media and foreign journalists cannot suppress evidence of rampant corruption at all levels. A well-informed international business executive estimates that illicit payments absorb 30-40 percent of outlays on public construction projects (2012 interview). Chinese press accounts report that "the departments of government services, government project bidding, and. . government procurement. . . have long been rife with bribery" and that "services at local governments. . . are provided only after gifts are offered to officials. . . [such as] banquets, entertainment, shopping cards. . . and money" (LI Wenfang 2012).

Corruption threatens to undermine China's merit-based system of appointment and promotion. Reports surrounding the recent ouster of a "senior provincial leader" include charges of "selling lower-level party posts" (Brian Spegele 2012). Nepotism is reportedly commonplace "in government departments and state-owned enterprises" (Kevin McGeary 2012). Against this background, new findings indicating that promotions at the upper levels of China's hierarchy reflect factional ties, educational qualifications and tax delivery rather than success in managing economic growth take on added significance (Victor Shih, Christopher Adolph and Mingxing Liu 2012).

While such abuses partly reflect what Andrei Schleifer and Robert Vishny (1998) call the "grabbing hand," there is a larger pattern of systematic efforts to secure and redistribute resources in order to preserve and increase cohesion within the ruling groups and their associates and supporters. The institutional structures surrounding the selection, approval, financing execution of investment represent a major arena for such activity.

Access to investment opportunities, credit, and land are routinely used to buttress the current regime and its allies. Official approval (pizhun), an essential step in business formation and expansion, may be reserved for well-connected insiders, especially in sectors promising high

\footnotetext{
${ }^{88}$ China currently has over 120,000 state enterprises, mostly managed by provincial and local offices of the State-owned Assets Supervision and Administration Commission (Wenkui Zhang 2012).
} 
profits. China's state-owned banks specialize in lending to favored clients, particularly stateowned enterprises, at below-market rates and with lax repayment provisions. Allocation of land is similarly tilted in favor of official associates and clients. As in imperial times, the patronage economy is much in evidence: relatives and associates of top leaders readily parlay personal connections into lucrative business positions. As in the past, private entrepreneurs invest in informal security umbrellas to deflect arbitrary disruption of commercial activity. ${ }^{89}$

Although this system is not without advantages - as when China's government, by ordering state-owned banks to dispense massive loans, achieved the $\mathrm{V}$-shaped recovery that has eluded the U.S. economy following the 2008 financial crisis, the cost of such arrangements, although difficult to specify, is surely high. India's economy, which is no paragon of efficiency, has approached Chinese growth rates despite investing a far smaller fraction of GDP. Pouring cheap credit into the state sector increases financial risk, fuels outsized seasonal fluctuations, elevates capital intensity, contributes to sluggish job creation, and aggravates long-standing unemployment problems (T. Rawski 2002).

Thus far, the momentum of China's long boom, buoyed by high levels of personal saving, has pushed aside these costs and other seemingly daunting obstacles. External events, especially the advance of globalization, with the attendant expansion of overseas markets, international supply chains and transnational flows of capital and technology, have provided enormous benefits. Most important, perhaps, is the robust development of China's non-state economy, where steep expansion of productivity and retained earnings have sustained rapid growth despite the distortions, graft, and rent-seeking that bedevil the public sector.

Today, as in the mid-1990s, costs and pressures appear to be on the rise. Economic rebalancing and management of corruption represent areas where the state has failed to attain its own widely advertised objectives. In both instances, policy failure may reflect a clash between publicly stated objectives and the inner workings of China's elite politics and patronage economy. Although Beijing has vowed to lessen the economy's dependence on exports and investment since the late 1990s, the GDP share of fixed investment, already at unprecedented levels, continues to rise. Recent infrastructure failures, such as the 2011 highspeed train disaster, highlight the costs of a system that combines massive investment with rampant corruption. Objections from state-run companies, which constitute "some of the most formidable opponents of change," stymied a major effort by the outgoing HU Jintao-WEN Jiabao administration to "narrow the vast gap between China's rich and poor" and thus spur the growth of consumption (Davis 2012).

Repeated announcements of anti-corruption drives - most recently in the form of experiments requiring local officials in several Guangdong districts to divulge their personal assets (ZHENG Caixiong 2012), have produced no visible results: China's score in Transparency International's corruption perceptions index was the same in 2010 as in 2001, as was its relative position: better than India or Russia, but worse than Turkey or Brazil.

Inability to implement policy changes advanced by top leaders raises the possibility that China has moved from a flexible and effective system of "authoritarian resilience" (Andrew

\footnotetext{
${ }^{89} \mathrm{~A}$ typical description notes that "the price that private entrepreneurs had to pay to ensure political protection was in the form of de facto extortion on the part of cadres" (Kellee Tsai 2002, p. 128).
} 
Nathan, 2003) to a new stage in which clashes among inner-party factions and powerful interest groups obstruct efforts to address widely-recognized difficulties (Cheng Li, 2012).

Equally striking is growing evidence of disaffection among successful participants in the Chinese system, many of whom are reportedly considering overseas migration. "You can feel the anxiety of the ultra-wealthy and even of the political elite. They feel there's no security for their wealth or possessions, and that their assets could be taken away at any time. Nobody feels protected against the system anymore." 90

These observations raise a series of questions:

Can the current institutional structure continue to support rapid growth as population ageing, a declining labor force, and rebalancing efforts lower household saving rates? As rising wages erode long-standing comparative advantage in labor-intensive industries? As technological advance eliminates easy gains from absorbing imported equipment and manufacturing processes? As limited enforcement of intellectual property rights inflicts growing damage on domestic innovators and discourages FDI? If international recession and protectionism slow the growth of world trade?

If, as is widely argued both within and outside China (e.g. World Bank 2012), continued dynamism will require substantial reform, is China's current political equilibrium sufficiently flexible to withstand large-scale dissolution of rents that might accompany a steep reduction in the share of credit reserved for government projects and state-owned enterprises? Or a noholds-barred effort to uproot corruption such as Hong Kong accomplished during the 1970s (Melanie Manion 2004)?

China's government channels growing resource flows to pursue strategic economic objectives, including long lists of specific products (e.g. large-scale passenger aircraft and engines) and technologies (e.g. nuclear power generation). Will state management of R\&D resources generate inefficiency and distortions on the same scale that is evident in stateinfluenced allocation of financial resources? Might such distortions, together with the consequences of graft and rent-seeking, limit resource flows available to dynamic sectors of China's economy, with negative consequences for aggregate productivity growth?

Could the outsized returns available to individuals and enterprises connected to China's power elite spark a diversion of talent from innovation and enterprise into politics and rentseeking, with negative consequences for incentives and hence for economic performance?

\footnotetext{
${ }^{90}$ Jamil Anderlini and Patti Waldmeir 2011, quoting an informant whom they describe as a "publishing and fashion mogul."
} 
Such concerns are not new. Writing in the mid-1990s, two prominent China specialists expressed doubts about the system's viability. Barry Naughton wrote that

The political system is simply not adequate to cope with the challenges that confront it. The dysfunctional political system might prevent the Chinese people from quickly building the kind of future system they would prefer; it might even jeopardize the achievements of recent decades (1995, p. 310).

Nicholas Lardy concluded his 1998 study by emphasizing the long-run importance of

... restructuring the banking system, particularly eventually allowing the emergence of private banks. ... [even though this] will require the state and the party to surrender a great deal of economic and political power. ... In the long run. . . delay is an almost certain path to a lower pace of economic growth, a declining rate of job creation, and thus an even greater challenge to political stability (pp. 221-222).

These deeply knowledgeable authors (and many others) underestimated the strength of China's unconventional system. Although there was no political reform, no major financial restructuring, no reduction in the dominance of China's big four state-owned banks, and no retreat from state-party control over financial institutions and resources, China's economy has continued its powerful advance in the face of major shocks from the Asian financial crisis of the late 1990 s and the 2008 global financial crash.

China's recent trajectory demonstrates the capacity of a dynamic economy to prosper despite heavy burdens. China's boom, like earlier growth spurts in Japan and Korea, confirms the wisdom of Joseph Schumpeter, who insisted that static efficiency was neither necessary nor sufficient for long-run dynamism (1943/2003, p. 83). It is equally true, however, that changing circumstances may undermine the effectiveness of institutional structures. As we have seen, the institutions of China's Qing dynasty supported immense demographic and geographic expansion, but proved incapable of responding constructively to new challenges arising from $19^{\text {th }}$-century globalization.

With the aid of hindsight, we can see that pessimistic predictions of the 1990s failed to comprehend China's dynamic potential. While striving to avoid this error, we must also recognize that, as is painfully evident from Japan's recent history, past success cannot guarantee the future efficacy of institutional structures.

Careful historical study must figure prominently in serious efforts to grapple with these and many other issues surrounding the historic path and future prospects for China's economy. This review reveals powerful complementarities between efforts to fathom the structures and mechanisms undergirding China's recent economic advance and studies of China's imperial past. Our survey demonstrates the insights that historical study can bring to the analysis of contemporary affairs. Several years of struggling to comprehend an immense body of historical scholarship has reinforced our conviction that contemporary developments can also provide fresh perspectives for addressing the vast storehouse of materials on the history of what once was and soon will become the world's largest national economy. 


\section{REFERENCES}

\section{Acemoglu, Daron and James A. Robinson. 2012. Why Nations Fail. New York: Crown Business}

Acemoglu, Daron, Simon Johnson and James A. Robinson. 2005. "Institutions as a Fundamental Cause of Long-Run Growth." In Handbook of Economic Growth. edited by Philippe Aghion and Steven N. Durlauf. Amsterdam and Boston: Elsevier, vol. 1.

Agriculture. 1980. Zhongguo nongye nianjian 1980 [China Agricultural Yearbook 1980]. Beijing: Nongye chubanshe.

Allen, Franklin, Jun Qian, and Meijun Qian. 2008. "China's Financial System: Past, Present, and Future. In China's Great Economic Transformation. Loren Brandt and Thomas G. Rawski eds. Cambridge and New York: Cambridge University Press, pp. 506-568.

Allen, Robert C, Jean-Pascal Bassino, Debin Ma, Christine Moll-Murata and Jan Luiten van Zanden. 2011. "Wages, Prices, and Living Standards in China, Japan, and Europe, 17381925" Economic History Review Vol. 64, No. S1, pp. 8-38.

Allen, Robert C. 2009. The British Industrial Revolution in Global Perspective. Cambridge University Press.

AN Baijie. 2013. "Official whose family owns 31 houses arrested." China Daily. 15 January, p. 5.

Anderlini, Jamil and Patti Waldmeir. 2011. "Chinese Doubt the Road Ahead." Financial Times November 5-6, 2011, p. 4.

Ashton, Basil, Kenneth Hill, Alan Piazza and Robin Zeitz. 1984. "Famine in China, 1958-61." Population and Development Review, Vol. 10, No. 4, pp. 613-645.

Bacon, Francis. 1620. New Instrument.

Baten, Joerg, Debin Ma, Stephen Morgan and Qing Wang. 2010. "Evolution of Living Standards and Human Capital in China in the 18-20th Centuries. "Explorations in Economic History 47, no. 3.

Beal, Edwin G. 1958. The Origin of Likin, 1853-1864. Cambridge MA: Chinese Economic and Political Studies, Harvard University; distributed by Harvard University Press.

Bengtsson, Tommy. 2004. Life Under Pressure: Mortality and Living Standards in Europe and Asia, 1700-1900. Cambridge, Mass.: MIT Press.

Bergere Marie-Claire. 1986., The Golden Age of the Chinese Bourgeoisie, 1911-1937.

Cambridge: Cambridge University Press, 1986.

Berliner, Joseph S. 1976. The Innovation Decision in Soviet Industry. Cambridge MA: MIT Press. 
Bian, Morris L. 2005. The Making of the State Enterprise System in Modern China. Cambridge MA: Harvard University Press.

Billingsley, Phil. 1998. Bandits in Republican China.. Stanford: Stanford University Press., 1988

Boserup, Ester. 1965. The Conditions of Agricultural Growth: The Economics of Agrarian Change under Population Pressure. New York: Aldine.

Bourgon, Jerome 2002. "Uncivil Dialogue: Law and Custom Did not Merge into Civil Law under the Qing," Late Imperial China. vol. 23, no.1 (June 2002): 50-90.

Bramall, Chris. 1989. Living Standards in Sichuan, 1931-1978. . London: Contemporary China Institute.

Bramall, Chris. 2000. Sources of Chinese Economic Growth, 1978-1996. Oxford: Oxford University Press.

Bramall, Chris. 2009. Chinese Economic Development. Abingdon UK and New York: Routledge.

Brandt, Loren. 1985. "Chinese Agriculture and the International Economy, 1870-1930: A Reassessment." Explorations in Economic History, 22:2, pp. 168-93.

Brandt, Loren. 1989. Commercialization and Agricultural Development: Central and Eastern China, 1870-1937. Cambridge; New York: Cambridge University Press.

Brandt, Loren and Arthur J. Hosios. 1996. Brandt, Loren \& Hosios, Arthur J, 1996. "Credit, Incentives, and Reputation: A Hedonic Analysis of Contractual Wage Profiles, " Political Economy, vol. 104(6), pages 1172-1226.

Brandt, Loren and Arthur J. Hosios. 2010. "Interest-Free Loans between Villagers, " Economic Development and Cultural Change, vol. 58(2), pages 345-372.

Brandt, Loren, Chang-tai Hsieh, and Xiaodong Zhu. 2008. "Growth and Structural Transformation in China," in China's Great Economic Transformation. Loren Brandt and Thomas G. Rawski eds. Cambridge and New York: Cambridge University Press, pp. 683728.

Brandt, Loren and Thomas G. Rawski. 2008. "China's Great Economic Transformation," in China's Great Economic Transformation. Loren Brandt and Thomas G. Rawski eds. Cambridge and New York: Cambridge University Press, pp. 1-26.

Brandt, Loren, Thomas G. Rawski, and John Sutton. 2008. "China's Industrial Development, " in China's Great Economic Transformation. Loren Brandt and Thomas G. Rawski eds. Cambridge and New York: Cambridge University Press, pp. 569-632.

Brandt, Loren and Thomas J. Sargent. 1989. "Interpreting New Evidence About China and U.S. Silver Purchases." Journal of Monetary Economics 23.1: 31-51.

Brandt, Loren, Johannes Van Biesebroeck, Wenkui Zhang and Yifan Zhang. In progress. 
Brandt, Loren, Johannes Van Biesebroeck and Yifan Zhang. 2012. "Creative Accounting or Creative Destruction? Firm-level Productivity Growth in Chinese Manufacturing." Journal of Development Economics, 97(2): 339-351.

Brandt, Loren and Xiaodong Zhu. 2000. "Redistribution in a Decentralized Economy: Growth and Inflation in China under Reform, " Journal of Political Economy, vol. 108(2), pages 422-451.

Brandt, Loren and Xiaodong Zhu. 2001. "Soft Budget Constraint and Inflation Cycles: A Positive Model of the Macro-Dynamics in China During Transition, " Journal of Development Economics, 64.2: 437-457.

Branstetter, Lee and Nicholas R. Lardy. 2008. "China's Embrace of Globalization," in China's Great Economic Transformation. Loren Brandt and Thomas G. Rawski eds. Cambridge and New York: Cambridge University Press, pp. 633-682.

Brook, Timothy. 1999. The Confusions of Pleasure: Commerce and Culture in Ming China. Berkeley; London: University of California Press.

Brook, Timothy. 2010. The Troubled Empire: China in the Yuan and Ming Dynasties. Cambridge, Mass.: Belknap Press of Harvard University Press.

Brown, Shannon R. 1978. "The Partially Opened Door: Limitations on Economic Change in China in the 1860s." Modern Asian Studies, 12:2, pp. 177-92.

Brown, Shannon R. 1979a. "The Ewo Filature: A Study in the Transfer of Technology to China in the 19th Century." Technology and Culture, 20:3, pp. 550-68.

Brown, Shannon R. 1979b. "The Transfer of Technology to China in the Nineteenth Century: The Role of Direct Foreign Investment." The Journal of Economic History, 39:1, pp. 18197.

Buck, John Lossing. 1937. Land Utilization in China, a Study of 16,786 Farms in 168 Localities, and 38,256 Farm Families in Twenty-Two Provinces in China, 1929-1933. Shanghai: The Commercial Press, 1937.

Buck, John Lossing. 1930. "Chinese Farm Economy: A Study of 2866 Farms in Seventeen Localiaties and Seven Provinces in China." Chicago: University of Chicago Press.

Burgess, John Stewart. 1928/1966. The Guilds of Peking. Taipei: Cheng-wen Publishing Co.

Cai, Fang. 2010. "Labor Market Development and Expansion of Urban and Rural Unemployment." In Fang Cai ed., Transforming the Chinese Economy. Leiden and Boston: Brill, pp. 85-114.

CAO Shuji. 1997. Zhongguo yi min shi. 中国移民史 [History of China's Migrants]. Fuzhou: Fujian renmin chubanshe.

CAO Shuji. 2001. Zhongguo renkoushi: Qing shiqi [History of China's Population: Qing Era]. Shanghai: Fudan daxue chubanshe. 
Ch'ü T’ung-tsu. 1980. Law and Society in Traditional China. Westport, CT: Hyperion Press.

Cha, Dong-Se, Kwang Suk Kim, and Dwight H. Perkins. 1997. The Korean Economy 19451995: Performance and Vision for the 21st century. Seoul: Korea Development Institute.

Chan, Anita, Richard Madsen, and Jonathan Unger. 1992. Chen Village under Mao and Deng. Berkeley: University of California Press.

Chan, Wellington K. K. 1977. Merchants, Mandarins and Modern Enterprise in Late Ch'ing China. Cambridge MA: Harvard University East Asian Research Center.

Chan, Wellington K. K. 1989/1996. " Sources of Capital for Modern Industrial Enterprises in late Ch'ing China," in Chinese Business Enterprise. Rajeswary Ampalavanar Brown ed. London: New York: Routledge, pp. 39-55.

Chang, Chung-li [Zhang Zhongli]. 1955. The Chinese Gentry: Studies on Their Role in Nineteenth Century Chinese Society. Seattle: University of Washington Press.

Chang, Chung-li [Zhang Zhongli]. 1962. The Income of the Chinese Gentry. Seattle: University of Washington Press.

Chang, John K. 1969. Industrial Development in Pre-Communist China; a Quantitative Analysis. Chicago: Aldine.

Chao, Kang. 1982. The Economic Development of Manchuria: The Rise of a Frontier Economy. Ann Arbor: Center for Chinese Studies, University of Michigan.

Chao, Kang. 1986. Man and Land in Chinese History: An Economic Analysis. Stanford, Calif.: Stanford University Press.

CHEN，Feng. 1992. 清代军费研究 [Qingdai junfei yanjiu; (A Study on Qing Military Expenditure)). Wuhan: Wuhan University Press, 1992.

Chen, Fu-mei Chang and Ramon H. Myers. 1978. "Customary Law and the Economic Growth of China during the Ch'ing Period." Ch'ing-shih wen-t'i 3.10 4-27.

Chen, Fu-mei and Ramon H. Myers. 1989/1996. "Coping With Transaction Costs: The Case of Merchant Associations in the Ch'ing Period." In Chinese Business Enterprise. Rajeswary Ampalavanar Brown ed. London: New York: Routledge, pp. 252-274.

Chen, Nai-Ruenn. 1967. Chinese Economic Statistics: A Handbook for Mainland China. Chicago: Aldine.

Chen, Zhihwu, Kaixiang Peng, and Weiping Yuan. 2010. "Robbery, Social Order, and Interest Rates in Modern China." Paper presented at Asian Historical Economics Conference, Tsinghua University, May 2010.

Cheng, Linsun. 2003. Banking in Modern China. Cambridge: Cambridge University Press.

Chow, Gregory C. 2002. China's Economic Transformation. Malden, Mass.: Blackwell Publishers. 
CH'UAN Hansheng, Zhongguo jingjishi yanjiu, (Research on Chinese Economic History) vol. 1. Taipei: Taoshan Publishers, 1990

Ch'uan, Han-sheng, and Richard A. Kraus. 1975. Mid-Ch'ing Rice Markets and Trade: An Essay in Price History. Cambridge, Mass.: East Asian Research Center, Harvard University: distributed by Harvard University Press.

Chung, P-Y. P.Y. Stephanie. 2010. "Chinese Tong as British Trust: Institutional Collisons and Legal Disputes in Urban Hong Kong, 1860s-1980s." Modern Asian Studies. 44.6:14091432.

Coble Jr. Parks. 2003. Chinese Capitalists in Japan's New Order: the Occupied Lower Yangzi, 12937-=1945. Berkeley and Los Angeles: University of California Press.

Coble, Parks M., Jr. 1986. The Shanghai Capitalists and the Nationalist Government, 19271937. $2^{\text {nd }}$ edition. Cambridge MA: Harvard University Council on East Asian Studies.

Compendium. 2010. Xin Zhongguo liushinian tongji ziliao huibian 1949-2008 [China Compendium of Statistics 1949-2008]. Beijing: China Statistics Press.

Davis, Bob. "China Tries to Shut Rising Income Gap." Wall Street Journal. 11 December, p. A14.

De Vries, Jan. The Industrious Revolution: Consumer Demand and the Household Economy, 1650 to the Present. Cambridge, Cambridge Univ. Press, 2008.

De Vries, Jan and Ad van der Woude. 1997. The First Modern Economy: Success, Failure, and Perseverance of the Dutch Economy, 1500-1815. Cambridge and New York: Cambridge University Press.

Deng, Gang [Kent G. Deng]. 1997. Chinese Maritime Activities and Socioeconomic Development, c. 2100 B.C.-1900 A.D. Westport, CT: Greenwood Press, 1997.

DENG，Jianpeng (邓建鹏). 2006. 财产权利的贫困-中国传统民事法研究 [Caichan quanli de pinkun; The Poverty of Property Rights - Studies on Traditional Chinese Civil Law]. Beijing: Falü chubanshe.

Deng, Kent G. [Gang Deng] 2000. "A Critical Survey of Recent Research in Chinese Economic History." The Economic History Review, 53:1, pp. 1-28.

Deng, Kent G. 2003. "Development and Its Deadlock in Imperial China, 221 B.C. -1840 A.D." Economic Development and Cultural Change, 51:2, pp. 479-522.

Dickson, Bruce. 2008. Wealth into Power: The Communist Party's Embrace of China's Private Sector. New York: Cambridge University Press.

Dikötter, Frank. 2006. Exotic Commodities: Modern Objects and Everyday Life in China. New York: Columbia University Press.

Dikötter, Frank. 2010. Mao's Great Famine: The History of China's Most Devastating Catastrophe, 1958-1962. New York: Walker \& Co. 
Dittrich, Scott R., and Ramon H. Myers. 1971. "Resource Allocation in Traditional Agriculture: Republican China, 1937-1940." The Journal of Political Economy 79 (4): 887-896.

Donadio, Rachel. 2010. "Chinese Remake the 'Made in Italy' Fashion Label, " New York Times, 13 September 2010.

Donnithorne, Audrey. 1967. China's Economic System. New York: Praeger.

Donnithorne, Audrey. 1972. "China's Cellular Economy: Some Economic Trends Since the Cultural Revolution." China Quarterly no. 52, pp. 605-619.

Duara, Prasenjit. 1988. Culture, Power, and the State: Rural North China, 1900-1942. Stanford, Calif.: Stanford University Press.

Eastman, Lloyd. 1984. Seeds of Destruction: Nationalist China in War and Revolution, 19371949. Stanford: Stanford University Press.

Ebrey, Patricia B. 2010. The Cambridge illustrated history of China. Cambridge: Cambridge University Press.

Economist. 2005. "Rong Yiren." Obituary posted at http://www.economist.com/node/5107693

Elleman, Bruce A. and S.C.M. Paine. 2010. Modern China: Continuity and Change 1644 to the Present. Boston: Prentice Hall

Elliot, Mark. The Manchu Way: The Eight Banners and Ethnic Identity in Late Imperial China. Stanford: Stanford University Press, 2001

Elman, Benjamin A. 2000. A Cultural History of Civil Examinations in Late Imperial China. Berkeley: University of California Press.

Elman, Benjamin A. 2005. On Their Own Terms: Science in China, 1550-1900. Cambridge, Mass.: Harvard University Press.

Elvin, Mark. 1973. The Pattern of the Chinese Past. Stanford: Stanford University Press.

Elvin, Mark. 2010. "The Environmental Impasse in Late Imperial China." In Brantley Womack ed., China's Rise in Historical Perspective. Lanham MD: Rowman \& Littlefield, pp. 152169.

Faure, David. 2006. China and Capitalism: A History of Business Enterprise in Modern China. Hong Kong: Hong Kong University Press.

Faure, David. 1989/1996. "The Lineage as Business Company: Patronage versus Law in the Development of Chinese Business, " in Chinese Business Enterprise. Rajeswary Ampalavanar Brown ed. London; New York: Routledge, pp. 82-106.

Feuerwerker, Albert. 1958. China's Early Industrialization: Sheng Hsüan-huai (1844-1916) and Mandarin Enterprise. Cambridge MA: Harvard University Press. 
Feuerwerker, Albert. 1961. "Materials for the Study of the Economic History of Modern China." The Journal of Economic History, 21:1, pp. 41-60.

Feuerwerker, Albert. 1968. The Chinese Economy, 1912-1949. Ann Arbor: University of Michigan, Center for Chinese Studies.

Feuerwerker, Albert. 1970. "Handicraft and Manufactured Cotton Textiles in China, 18711910." Journal of Economic History, XXX, 2, pp. 338-378.

Feuerwerker, Albert. 1980. "Economic Trends in the Late Ch'ing Empire, 1870-1911." Chapter 1 in The Cambridge History of China. Volume 11 Part 2. Cambridge: Cambridge University Press.

Feuerwerker, Albert. 1988. Review of Kang Chao, Man and Land in Chinese History. American Historical Review 93.2, p. 477.

Feuerwerker, Albert. 1992. "Presidential Address: Questions About China's Early Modern Economic History That I Wish I Could Answer." The Journal of Asian Studies, 51:4, pp. 757-69.

Flynn, Dennis O. and Arturo Giraldez. 1994. "China and the Manila Galleons." In Japanese Industrialization and the Asian Economy, ed. A. J. H. Latham and Heita Kawakatsu, pp. 71-90. London: Routledge.

Flynn, Dennis O. and Arturo Giraldez. 1995. "Arbitrage, China, and World Trade in the Early Modern Period," Journal of the Economic and Social History of the Orient 38.4: 429-448.

Frank, Andre Gunder. 1998. ReOrient: Global Economy in the Asian Age. Berkeley: University of California Press.

Fukuyama, Francis. 2011. The Origins of Political Order: From Prehuman Times to the French Revolution. New York: Farrar, Straus and Giroux.

Furth, Charlotte 1983. "Intellectual change: from the Reform Movement to the May Fourth Movement, 1895-1920." In John K. Fairbank and Albert Feuerwerker eds., chapter 7, The Cambridge History of China Vol. 12: Republican China 1912-1949, Part 1, Chapter 7.

Gardella, Robert. 1992 "Squaring Accounts: Commercial Bookkeeping Methods and Capitalist Rationalism in Late Qing and Republican China" The Journal of Asian Studies, Vol. 51, No. 2 (May, 1992), pp. 317-339.

Gardella, Robert. 1994. Harvesting Mountains: Fujian and the China Tea Trade, 1757-1937. Berkeley: University of California Press.

Garnaut, Ross et al. 2005. China's Ownership Transformation: Process, Outcomes, Prospects. Washington DC: World Bank.

GE Jianxiong et al. 2001. Zhongguo renkoushi [Population History of China]. 6 vols. Shanghai: Fudan University Press.

Godley, Michael R. 1981. The Mandarin-Capitalists from Nanyang: Overseas Chinese Enterprise in the Modernization of China, 1893-1911. Cambridge and New York: Cambridge University Press. 
Greenberg, Michael. 1951. British Trade and the Opening of China 1800-1842. Cambridge: Cambridge University Press.

Greif, Avner. 2006. Institutions and the Path to the Modern Economy: Lessons from Medieval Trade. Cambridge: Cambridge University Press.

Greif, Avner. 2008. "Commitment, Coercion and Markets: The Nature and Dynamics of Institutions Supporting Exchange." Chapter 28 In Handbook for New Institutional Economics. Edited by Claude Claude Ménard and Mary M. Shirley. Springer.

GUAN, Hanhui and LI Daokui. 2010. "明代GDP及结构试探 [Tentative Discussion of China's Ming Dynasty GDP and its Structure] " Jingjixue jikan [Economic Quarterly]: 3, pp. 787828.

HAMASHITA Takeshi. 2006. 中國近代經濟史研究：清末海關財政與通商口岸市場圈， [Studies in China's Modern Economic History: Maritime Customs Finance and Treaty-Port Market Networks During Late Qing]. Translated by 高淑娟、孫彬. Nanjing: Jiangsu renmin chubanshe.

HAMASHITA Takeshi. 2008. China, East Asia and the Global Economy. Ed. Linda Grove and Mark Selden. Abingdon and New York: Routledge

HAN Fei-tzu. N.d. The Complete Works of Han Fei-tzu. Available at http://xtf.lib.virginia.edu/xtf/view?docld=2003_Q4/uvaGenText/tei/z000000042.xml.

Hao, Yen-p'ing. 1986. The Commercial Revolution in Nineteenth-century China: the Rise of Sino-Western Mercantile Capitalism. Berkeley: University of California Press.

Harrell, Stevan. 1995. Chinese Historical Microdemography. Berkeley: University of California Press.

Hartwell, Robert. 1962. "A Revolution in the Chinese Iron and Coal Industries During the Northern Sung, 960-1126 A.D." The Journal of Asian Studies, 21:2, pp. 153-62.

Hayami, Akira, Osamu Saito and Ronald Toby, eds. 2004. Economic History of Japan, 16001990. Oxford and New York: Oxford University Press.

Hayford, Charles W. 1990. To the People: James Yen and Village China. New York: Columbia University Press.

HE Bingdi [Ping-ti Ho]. 1966. Zhongguo huiguan shilun [Historical survey of China's Landsmannschaften]. Taipei: Xuesheng shuji.

Heilmann, Sebastian. 2008. "From Local Experiments to National Policy: The Origins of China's Distinctive Policy Process." China Journal no. 59, pp. 1-30.

Heilmann, Sebastian and Elizabeth J. Perry eds. 2011. Mao's Invisible Hand: The Political Foundations of Adaptive Governance in China. Cambridge MA: Harvard University East Asia Center. 
Hershatter, Gail. 1986. The Workers of Tianjin, 1900-1949. Stanford, Calif.: Stanford University Press.

Ho, Franklin L. 1967. "The Reminiscences of Ho Lien (Franklin L Ho) as Told to Crystal Lorch Seidman." China Oral History Project. Columbia University Library: New York.

Ho, Ping-ti. 1954. "The Salt Merchants of Yang-Chou: A Study of Commercial Capitalism in Eighteenth-Century China." Harvard Journal of Asiatic Studies, 17:1/2, pp. 130-68.

Ho, Ping-ti. 1956. "Early-ripening Rice in Chinese History. Economic History Review. 9.2: 200218

Ho, Ping-ti. 1959. Studies on the Population of China, 1368-1953. Cambridge: Harvard University Press.

Ho, Ping-ti. 1962. The Ladder of Success in Imperial China: Columbia University Press.

Holz, Carsten A. 2003. China's Industrial State-Owned Enterprises: Between Profitability and Bankruptcy. Singapore and Hong Kong: World Scientific.

Homer, Sidney and Richard Sylla. 2005. History of Interest Rates. Hoboken, N.J. : Wiley.

Hou, Chi-ming. 1965. Foreign Investment and Economic Development in China, 1840-1937. Cambridge: Harvard University Press.

HOU Fengyun. 1999. Zhongguo renliziben xingcheng ji xianzhuang [Formation and Present Circumstances of Human Capital in China]. Beijing: Jingji kexue chubanshe.

Hsiao, Liang-lin. 1974. China's Foreign Trade Statistics, 1864-1949. Cambridge, Mass.: East Asian Research Center Harvard University: distributed by Harvard University Press.

Hsu, S. Philip, Yu-Shan Wang and Suisheng Zhao eds. 2011. In Search of China's Development Model: Beyond the Beijing Consensus. London: Routledge.

Hsueh, Li-min, Chen-kuo Hsu, and Dwight H. Perkins. 2001. Industrialization and the State: the Changing Role of the Taiwan Government in the Economy, 1945-1998. Cambridge, Mass.: Harvard Institute for International Development.

HU Angang. 2010. Government Transformation and Public Finance." In Fang Cai ed., Transforming the Chinese Economy. Leiden and Boston: Brill, pp. 149-199.

Huang, Philip C. 1985. The Peasant Economy and Social Change in North China. Stanford, Calif.: Stanford University Press.

Huang, Philip C. 1990. The Peasant Family and Rural Development in the Yangzi Delta, 13501988. Stanford, Calif.: Stanford University Press.

Huang, Ray. 1974. Taxation and Governmental Finance in Sixteenth-century Ming China. (Cambridge studies in Chinese history, literature and institutions.). Cambridge: Cambridge University Press. 
Ichiko, Chūzō. 1980. "Political and Institutional Reform 1901-11." In The Cambridge History of China, Volume 11 Part 2 Late Ch'ing, 1800-1911.

ILO. 1937. International Labour Office. The World Textile Industry: Economic and Social Problems. 2 vols. Geneva: ILO.

Industry. 2000. Zhongguo gongye jiaotong nengyuan 50-nian tongji ziliao huibian 1949-1999 [50-year Compendium of Statistics on China's Industry, Transport, and Energy 19491999]. Beijing: Zhongguo tongji chubanshe.

Irigoin, Alejandra. 2009. "The End of a Silver Era: The Consequences of the Breakdown of the Spanish Peso Standard in China and the United States, 1780s-1850s," Journal of World History 20.2: 215-20.

Isett, Christopher Mills. 2007. State, Peasant, and Merchant in Qing Manchuria, 1644-1862. Stanford, Calif.: Stanford University Press.

Ishikawa, Shigeru. 1983. "China's Economic Growth Since 1949 - An Assessment." The China Quarterly, 94, pp 242-281.

IWAI Shigeki 岩井茂樹. 2004. Chūgoku kinsei zaiseishi no kenkyū 中国近世財政史の研究 [A Study of China's Early Modern Fiscal History]. Kyoto: Kyoto University Press.

JIN Guantao and LIU Qingfeng 2011a，兴盛与危机，论中国社会超稳定结构 [The Cycle of Growth and Decline, On the Ultrastable Structure of Chinese Society]), Beijing: China Law Press China.

JIN Guantao and LIU Qingfeng. 2011b. xxx 开放中的变迁：再论中国社会超稳定结构 [The Transformation of Chinese Society (1840-1956): The Fate Its Ultrastable Structure in Modern Times]. Beijing: China Law Press China.

JING Su and LUO Lun. 1978. Landlord and Labor in Late Imperial China: Case Studies from Shandong. Cambridge, Mass.: Council on East Asian Studies, Harvard University: distributed by Harvard University Press.

Johnson, Linda Cooke. 1993. "Shanghai: An Emerging Jiangnan Port, 1683-1840," in Cities of Jiangnan in Late Imperial China. Linda Cooke Johnson ed. Albany: State University of New York Press, pp. 151-181.

Jones, E. L. 1988. Growth Recurring: Economic Change in World History. Oxford \& New York: Oxford University Press.

Kann, Eduard. 1975. The Currencies of China: an Investigation of Silver \& Gold Transactions Affecting China with a Section on Copper. New York: AMS Press.

Keller, Wolfgang, Ben Li and Carol H. Shiue. 2010. "China's Foreign Trade: Perspectives from the Past 150 Years." Unpublished.

Keller, Wolfgang, Ben Li and Carol H. Shiue. 2011. "The Evolution of Domestic Trade Flows When Foreign Trade is Liberalized: Evidence from the Chinese Maritime Customs Service." Unpublished conference paper. 
Keller, Wolfgang, Ben Li and Carol H. Shiue. 2012. "Shanghai's Trade, China's Growth: Continuity, Recovery, and Change Since the Opium War." NBER Working Paper 17754.

King, Frank H. H. 1965. Money and Monetary Policy in China, 1845-1895. Cambridge: Harvard University Press.

King, Frank H. H. 1969. A Concise Economic History of Modern China (1840-1961). [New York]: Praeger.

Kirby, William C. 1984. Germany and Republican China. Stanford University Press.

Kirby, William C. 1990. "Continuity and Change in Modern China: Economic Planning on the Mainland and on Taiwan, 1943-1958." The Australian Journal of Chinese Affairs 24: 121-141.

Kirby, William C. 1995. "China, Unincorporated: Company Law and Business Enterprise in Twentieth Century China." Journal of Asian Studies 54, no. 1: 43-63.

KISHIMOTO Mio. 2003. "Ming Qing shidai de 'Zhaojia huidu' wenti" [The Problem of "Compensation and Repurchase" in Ming and Qing], in YANG Yifan (ed.), Riben xuezhe kaozheng Zhongguo fazhishi zhongyao renwen xuanye [Translations of Important Articles on Chinese Legal system by Japanese Scholars, vol. 4, Ming and Qing]. Beijing: Chinese Social Science Press, pp. 423-459.

KISHIMOTO Mio. 2011. "Property Rights, Land and Law in Imperial China." Chapter 4 in Debin Ma and Jan Luiten van Zanden eds., Law and Long-term Economic Development, an Eurasian Perspective. Stanford: Stanford University Press.

Kraus, Richard A. 1980. Cotton and Cotton Goods in China, 1918-1936. New York: Garland Pub.

Kubo, Toru., 2005. "The Tariff Policy of the Nationalist Government, 1929-36: A Historical Assessment." In Kaoru Sugihara ed., chapter 7, Japan, China, and the Growth of the Asian International Economy, 1850-1949. Oxford: Oxford University Press, pp. 145-176.

Kuhn, Philip A. 1986 "The Development of Local Government." In John K. Fairbank and Albert Feuerwerker eds., The Cambridge History of China Vol. 13: Republican China 1912-1949, Part 2. Cambridge: Republican China 1912-1949, Part 2. Eds. John K. Fairbank and Albert Feuerwerker. Cambridge University Press.

Kuhn, Philip A. 2002. Origins of the Modern Chinese State. Stanford: Stanford University Press.

Kung, James Kai-sing and Chen Shuo. 2011. "The Tragedy of the Nomenklatura: Career Incentives and Political Radicalism during China's Great Leap Famine." American Political Science Review, 105, pp 27-45.

Kuo, Ting-yee and Kwang-ching Liu. 1978. "Self-strengthening: the Pursuit of Western Technology." In John K. Fairbank (ed.), The Cambridge History of China, Vol.10, part 1, pp. 491-542. 
Kuran, Timur. 1995. "The Inevitability of Future Revolutionary Surprises. American Journal of Sociology 100.6: 1528-1551

Kwan, Man Bun. 2001. The Salt Merchants of Tianjin: State-Making and Civil Society in Late Imperial China. Honolulu: University of Hawai'i Press.

Lardy, Nicholas R. 1983. Agriculture in China's Modern Economic Development. Cambridge and New York: Cambridge University Press.

Lardy, Nicholas R. 1994. China in the World Economy. Washington DC: Institute for International Economics.

Lau, Lawrence J., Yingyi Qian, and Gerard Roland, 2001. "Reform without Losers: An Interpretation of China's Dual-Track Approach to Transition, " Journal of Political Economy, vol. 108(1), pages 120-143.

Lavely, William and R. Bin Wong. 1998. "Revising the Malthusian Narrative: The Comparative Study of Population Dynamics in Late Imperial China." Journal of Asian Studies 57.3: 714-748

Lee, James Z. and Cameron D. Campbell. 1997. Fate and Fortune in Rural China: Social Organization and Population Behavior in Liaoning, 1774-1873. New York: Cambridge University Press.

Lee, James Z., Cameron Campbell, and Feng Wang. 2002. "Positive Check or Chinese Checks?" The Journal of Asian Studies, 61:2, pp. 591-607.

Lee, James Z. and Feng Wang. 1999. One Quarter of Humanity: Malthusian Mythology and Chinese Realities, 1700-2000. Cambridge, Mass.: Harvard University Press.

Lee, Ronald and Michael Anderson. 2002. "Malthus in State Space: Macro EconomicDemographic Relations in English History, 1540 to 1870." Journal of Population Economics, 15:2, pp. 195-220.

Leonard, Jane Kate. 1996. Controlling from afar: the Daoguang Emperor's management of the Grand Canal Crisis, 1824-1826. Ann Arbor: University of Michigan Center for Chinese Studies

Levy, Marion J. 1953. "Contrasting Factors in the Modernization of China and Japan." Economic Development and Cultural Change 2.3: 161-197.

LI Bozhong. 1998. Agricultural Development in Jiangnan, 1620-1850. New York: St. Martin's Press.

LI Bozhong. 2000. Jiangnan de zaoqi gongyehua: 1550-1850 nian [Jiangnan's Early Industrialization, 1550-1850]. Beijing: Shehui kexue wenxian chubanshe.

LI Bozhong. 2002. Lilun, fangfa, fazhan qushi: Zhongguo jingjishi yanjiu xintan [Theory, Method, Development Trends: New Directions for Research on China's Economic History]. Beijing: Qinghua daxue chubanshe. 
LI Bozhong. 2003. Duoshijiao kan Jiangnan jingjishi, 1250-1850 [Multi-perspective View of Jiangnan's Economic History, 1250-1850]. Beijing: Shenghuo, dushu, xinzhi sanlian shudian.

LI Bozhong. 2010a. Jiangnan de zaoqi gongyehua: 1550-1850 [Jiangnan's Early Industrialization, 1550-1850]. Beijing: Zhongguo renmin daxue chubanshe.

LI Bozhong. 2010b. Zhongguo de zaoqi jindai jingji: 1820 niandai Huating-Louxian diqu GDP yanjiu [China's Early Modern Economy: A Study of Regional GDP in Huating and Lou Counties during the 1820s]. Beijing: Zhonghua shuju.

LI Hong. 1993. Zhongguo qiche gongye jingji fenxi [Economic Analysis of China's Auto Industry]. Beijing: Zhongguo renmin daxue chubanshe.

LI Lanqing. 2009. Breaking Through: the Birth of China's Opening-Up Policy. Translated by Ling Yuan and Zhang Siying. Oxford and New York: Oxford University Press.

Li, Hongbin and Li-An Zhou. 2005. "Political Turnover and Economic Performance: The Incentive Role of Personnel Control in China" (with Hongbin Li), Journal of Public Economics 89:1743-1762.

Li, Lillian M. 1981. China's Silk Trade: Traditional Industry in the Modern World, 1842-1937. Cambridge, Mass.: Council on East Asian Studies.

Li, Lillian M. 2007. Fighting Famine in North China: State, Market, and Environmental Decline, 1690s-1990s. Stanford: Stanford University Press.

Liang, Ernest P. 1982. China, Railways and Agricultural Development, 1875-1935. Chicago, III.: University of Chicago Dept. of Geography.

LIANG, Qichao. 梁启超选集 (Selected Works of LIANG Qichao) edited by LI, H.X and WU, J.X. Shanghai: Shanghai People's Press, 1984, pp. 27-32.

Lieu, D.K. [LIU Ta-chün]. 1936. The Growth and Industrialization of Shanghai. Shanghai: Institute of Pacific Relations.

Lin, Justin Yifu. 1988. "The Household Responsibility System in China's Agricultural Reform: A Theoretical and Empirical Study." Economic Development and Cultural Change, 36:3, pp. S199-S224.

Lin, Justin Yifu. 1992. "Rural Reforms and Agricultural Growth in China." The American Economic Review, 82:1, pp. 34-51.

Lin, Justin Yifu. 1995. "The Needham Puzzle: Why the Industrial Revolution Did Not Originate in China." Economic Development and Cultural Change, 43:2, pp. 269-92.

Lin, Justin Yifu, Fang Cai, and Zhou Li. 2003. The China Miracle: Development Strategy and Economic Reform. Hong Kong: Chinese University Press.

Lin, Man-houng. 2006. China Upside Down: Currency, Society, and Ideologies, 1808-1856. Cambridge, Mass.: Harvard University Asia Center: Distributed by Harvard University Press. 
LIU Shijie. 1987. Ming-Qing shidai Jiangnan shizhen yanjiu [Studies on Jiangnan cities and towns in Ming and Qing]. Beijing: Chinese Academy of Social Science Press.

LIU Zhongyuan, 捕蛇者說 (The tale of a snake-catcher).

https//www.baike.baidu.com/view/98403.htm

Liu, Guanglin. 2005. "Wrestling for Power: The State and the Economy in Later Imperial China, 1000-1770." Ph.D. Thesis, Harvard University.

Liu, Ta-chung and Kung-chia Yeh. 1965. The Economy of the Chinese Mainland: National Income and Economic Development, 1933-1959. Princeton, N.J.: Princeton University Press.

Liu, Ts'ui-jung. 2001. Asian Population History. Oxford; New York: Oxford University Press.

LONG Denggao. 2010. "The Diversification of Land Transactions in Late Imperial China." Conference presentation, Tsinghua University, May.

Lyons, Thomas P. and Victor Nee eds. 1994. The Economic Transformation of South China: Reform and Development in the Post-Mao Era. Ithaca, NY: Cornell University East Asia Program.

Ma, Debin. 2004a, "Why Japan, Not China, Was the First to Develop in East Asia, Lessons from Sericulture 1850-1937." Economic Development and Cultural Change volume 52, No. 2, pp. 369-394.

Ma, Debin 2004b. "Growth, Institutions and Knowledge: A Review and Reflection on the Historiography of 18th-20th Century China." Australian Economic History Review, (Special Issue on the Economic History of Asia) Vol. 44, Issue 3.

Ma, Debin. 2005. "Between Cottage and Factory: the Evolution of Chinese and Japanese SilkReeling Industries in the Latter Half of $19^{\text {th }}$ Century." Journal of The Asia Pacific Economy, vol. 10, No. 2, 195-213.

Ma, Debin. 2008. "Economic Growth in the Lower Yangzi Region of China in 1911-1937: A Quantitative and Historical Analysis." Journal of Economic History, vol. 68, no. 2: 355-392.

Ma, Debin, 2011a "Rock, Scissors, Paper: the Problem of Incentives and Information in Traditional Chinese State and the Origin of Great Divergence". LSE Economic History Working Paper No.152, available at http://www2.Ise.ac.uk/economicHistory/workingPapers/2011/WP152.pdf

Ma, Debin. 2011 b. "Law and Economic Change in Traditional China: A 'Legal Origin' Perspective on the Great Divergence, " chapter 3 in Law and Long-Term Economic Development: A Eurasian Perspective. Debin Ma and Jan Luiten van Zanden eds. Stanford: Stanford University Press.

Ma, Debin 2011c. "The Rise of Modern Shanghai: 1900-1936: An Institutional Perspective," chapter 2 in Billy So and Ramon H. Myers ed., The Treaty Port Economy in Modern China: 
Emperical Studies of Institutional Change and Economic Performance. Berkeley: University of California Press.

Ma, Debin. 2012. "Political Institutions and Long-run Economic Trajectory: Some Lessons from Two Millennia of Chinese Civilization." In M. Aoki, T. Kuran and G. Roland, eds., Institutions and Comparative Economic Development, Chap. 4. Basingstoke: Palgrave Macmillan.

Ma, Debin. 2013. "Chinese Money and Monetary System, 1800-2000, Overview." I chapter 6, in Gerard Caprio, (ed.), Handbook of Key Global Financial Markets, Institutions, and Infrastructure. i: 57-64. Oxford: Elsevier Inc.

Ma, Junya. 2008., "Traditional Finance and China's Agricultural Trade, 1920-1933" Modern China. Vol. 34, No. 3, July 2008,pp. 344-371.

Macauley, Melissa. 1998. Social Power and Legal Culture: Litigation Masters in Late Imperial China. Stanford: Stanford University Press.

Maddison, Angus. 2001. The World Economy: A Millennial Perspective. Paris: Development Centre of the Organisation for Economic Co-operation and Development.

Maddison, Angus. 2007. Chinese Economic Performance in the Long Run. 2nd ed, rev. and updated. Paris: Development Centre of the Organisation for Economic Co-operation and Development.

Manion, Melanie. 2004. Corruption by Design: Building Clean Government in Mainland China and Hong Kong. Cambridge, MA: Harvard University Press.

Mann, Susan. 1987. Local Merchants and the Chinese Bureaucracy, 1750-1950. Stanford: Stanford University Press.

Manshū kaihatsu. 1964-65. Manshū kaihatsu yonjū nenshi [Forty-year History of Development in Manchuria]. 3 vols. Tokyo: Manshū kaihatsu yonjū nenshi kankōkai.

Mantzavinos, Chris, Douglass C. North, and Syed Shariq. 2004. "Learning, Institutions, and Economic Performance "Perspectives on Politics 2, no. 1.

Maskin, Eric, Yingyi Qian, and Chenggang Xu. 2000. "Incentives, Information, and Organizational Form." Review of Economic Studies, vol. 67(2), pages 359-78.

Mayers, William Frederick and G. M. H. Playfair. 1897/1966. The Chinese Government: A Manual of Chinese Titles, Categorically Arranged and Explained, with an Appendix. Taipei: Ch'eng-Wen Pub. Co.

McAfee, R. Preston and John McMillan. 1995. "Organizational Diseconomies of Scale." Journal of Economics \& Management Strategy, 4:3, pp. 399-426.

McCloskey, Deirdre N. 2010. Bourgeois Dignity: Why Economics Can't Explain the Modern World. Chicago: University of Chicago Press. 
McCloskey, Donald N. and John Nash. 1984. "Corn at Interest: the Extent and Cost of Grain Storage in Medieval England." Vol. 74, No. 1: 174-187.

McElderry, Andrea. 1976. Shanghai Old-style Banks (ch'ien-chuang), 1800-1935: A Traditional Institution in a Changing Society. Ann Arbor: Center for Chinese Studies, University of Michigan, 1976.

McElderry, Andrea. 1995. "Securing Trust and Stability." in Chinese Business Enterprise. Rajeswary Ampalavanar Brown ed. London: New York: Routledge, pp. 27-44.

McGeary, Kevin 2012. "Guangdong Province chooses 3 areas to pilot anti-corruption measures amid deep mistrust." Posted December 14. http://www. thenanfang.com/blog/guangdongprovince-chooses-3-areas-to-pilot-anti-corruption-measures-amid-deep-mistrust/ accessed 16 December 2012.

Miyakawa, Hisayuki. 1955. "An Outline of the Naito Hypothesis and its Effects on Japanese Studies of China." The Far Eastern Quarterly 14(4): 533-552.

MIYAZAKI Ichisada. 1976. China's Examination Hell. Translated by Conrad Shirokauer. NY and Tokyo: Weatherhill.

MIZOGUCHI Toshiyuki and UMEMURA Mataji. 1988. Kyū Nihon shokuminchi keizai tōkei: suikei to bunseki [Economic Statistics of Japan's Former Colonies: Estimation and Analysis]. Tokyo: Toyo Keizai Shinposha.

Mokyr, Joel. 1990. The Lever of Riches: Technological Creativity and Economic Progress. New York: Oxford University Press.

Mokyr, Joel. 2002. The Gifts of Athena: Historical Origins of the Knowledge Economy. Princeton [N.J.]: Princeton University Press.

Mokyr, Joel. 2009. The Enlightened Economy: an Economic History of Britain, 1700-1850. New Haven: Yale University Press.

Moll-Murata, Christine. "Chinese Guilds from the Seventeenth to the Twentieth Centuries: An Overview." International Review of Social History 53, no. Supplement (2008): 213-47.

Montinola, Gabriella, Yingyi Qian, and Barry R. Weingast. 1996. "Federalism, Chinese Style: The Political Basis for Economic Success." World Politics 48.1: 50-81.

Morawetz, David. 1978. Twenty-five Years of Economic Development, 1950 to 1975. Baltimore: Published for World Bank [by] Johns Hopkins Unversity Press.

Morck, Randall, and Fan Yang, 2011. "The Shanxi Banks." In Jonathan Koppell, ed. Origins of Shareholder Advocacy. London: Palgrave Macmillan.

Morse, Hosea Ballou. 1932. The Gilds of China. 2d ed. London, New York: Longmans, Green and Co., 1932.

Motono, Eiichi. 2000. Conflict and Cooperation in Sino-British Business, 1860-1911. New York: St. Martin's. 
MURAMATSU, Yuji. 1966. "A Documentary Study of Chinese Landlordism in Late Ch'ing and Early Republican Kiangnan." Bulletin of the School of Oriental and African Studies 29, no. 3 (1966): 566-99.

Murphey, Rhoads. 1977. The Outsiders: The Western Experience in India and China. Ann Arbor: University of Michigan Press.

Myers, Ramon H. 1970. The Chinese Peasant Economy: Agricultural Development in Hopei and Shantung, 1890.1949. Cambridge MA: Harvard University Press.

Myers, Ramon H. 1980. The Chinese Economy, Past and Present. Belmont CA: Wadsworth.

Myers, Ramon H. and Yeh-chien Wang. 2002. "Economic Developments, 1644-1800." In The Cambridge History of China, Volume 9 Part 1Part one: The Ch'ing Empire to 1800. Cambridge: Cambridge University Press.

Nakamura, James and Mataji Miyamoto. 1982. "Social Structure and Population Change: A Comparatuive Study of Tokugawa Japan and Ch'ing China." Economic Development and Cultural Change Vol. 30, No. 2.

Nathan, Andrew J. 2003. "Authoritarian Resilience." Journal of Democracy. 14.1: 6-17.

Naughton, Barry. 1995. Growing Out of the Plan: Chinese Economic Reform, 1978-1993. Cambridge [England]; New York, NY: Cambridge University Press.

Naughton, Barry. 2007. The Chinese Economy: Transitions and Growth. Cambridge: MIT Press. Naughton, Barry. 2008. "A Political Economy of China's Economic Transition." In China's Great Economic Transformation. Loren Brandt and Thomas G. Rawski eds. Cambridge and New York: Cambridge University Press, pp. 91-135.

Naughton, Barry. 2011. "Inside and Outside: The Modernized Hierarchy that Runs China." Paper prepared for Legal Order, The State and Economic Development, Conference held in Florence, Italy, September 2011.

NBS. 2007. Department of National Accounts, National Bureau of Statistics of China. Zhongguo guonei shengchanzongzhi hesuan lishi ziliao 1952-2004 [Data of Gross Domestic Product of China 1952-2004]. Beijing: Zhongguo tongji chubanshe.

Needham, Joseph. 1971. Science and Civilisation in China, Vol. 4: Physics and Physical Technology. Part III: Civil Engineering and Nautics. Cambridge: Cambridge University Press.

Needham, Joseph and Colin A. Ronan. 1978. The Shorter Science and Civilisation in China: An Abridgement of Joseph Needham's Original Text. Cambridge; New York: Cambridge University Press.

NEGISHI Tadashi. 1951. Shanhai no girudo [The Guilds of Shanghai]. Tokyo: 1951.

North, Douglass C. 1994. "Economic Performance through Time." American Economic Review Vol. 84, No. 3, pp. 359-368. 
North, Douglass C. and Robert P. Thomas. 1973. The Rise of the Western World; a New Economic History. Cambridge: Cambridge University Press.

Ohkawa, Kazushi and Henry Rosovsky. 1973. Japanese Economic Growth: Trend Acceleration in the Twentieth Century. Stanford, Calif.: Stanford University Press.

Olson, Mancur. 1965. The Logic of Collective Action; Public Goods and the Theory of Groups Cambridge MA: Harvard University Press, 1965.

Olson, Mancur. 1982. The Rise and Decline of Nations: Economic Growth, Stagflation, and Social Rigidities. New Haven: Yale University Press.

ŌSAWA, Masaaki. 1996. Tō Sō henkakuki nōgyō shakaishi kenkyū [On the Social History of Agriculture During the Tang-Song Transformation] Tokyo: Kyuko Shoin.

Pearson, Margaret. 2011. "Variety Within and Without: The Political Economy of Chinese Regulation." In Beyond the Middle Kingdom. Ed. Scott Kennedy. Stanford: Stanford University Press, pp. 25-43.

Pei, Minxin. 2006. China's Trapped Transition: The Limits of Developmental Autocracy. Cambridge MA: Harvard University Press.

PENG Kaixiang， with CHEN Zhiwu， YUAN Weiping and CAO Huining. 2009. “水浅而舟重: 近 代中国农村借贷中的市场机制" (Shallow Water and Heavy Boat: Market Mechanism in Modern Chinese Rural Credit) chapter in 中国工商业与金 融史的传统与变 迁 (The Evolution of Chinese Industry, Commerce and Finance, an International Symposium) edited by LIU Qiugen and MA Debin. Shijiazhuang, China: Hebei University Press.

PENG Xinwei. 1958. Zhongguo huobishi [History of Money in China]. Shanghai: Shanghai renmin chubanshe.

PENG, Xizhe. 1987. "Demographic Consequences of the Great Leap Forward in China's Provinces." Population and Development Review, vol. 13, no. 4, pp. 639-70.

Perdue, Peter C. 1996. "Military Mobilization in Seventeenth and Eighteenth-Century China, Russia, and Mongolia." Modern Asian Studies 30.4: 757-793

Perdue, Peter C. 1987. Exhausting the Earth: State and Peasant in Hunan, 1500-1850.

Cambridge, Mass.: Council on East Asian Studies Distributed by Harvard University Press.

Perdue, Peter C. 2005. China Marches West: The Qing Conquest of Central Eurasia. Cambridge, Mass.: Belknap Press of Harvard University Press.

Perkins, Dwight H. 1969. Agricultural Development in China, 1368-1968. Chicago: Aldine.

Perkins, Dwight H. 1967. "Government as an Obstacle to Industrialization: The Case of Nineteenth-Century China." The Journal of Economic History, 27:4, pp. 478-92.

Perkins, Dwight H. 1995. "The Transition from Central Planning: East Asia's Experience," in Social Capability and Long-term Economic Growth. Bon Ho Koo and Dwight H. Perkins 
eds. Houndmills, Basingstoke, Hampshire \& New York, Macmillan \& St. Martin's Press, pp. 221-41.

Perkins, Dwight H. and Thomas G. Rawski. 2008. "Forecasting China's Economic Growth to 2025," in China's Great Economic Transformation. Loren Brandt and Thomas G. Rawski eds. Cambridge and New York: Cambridge University Press, pp. 829-886.

Perry, Elizabeth J. and Merle Goldman. 2007. Grassroots Political Reform in China. Cambridge MA: Harvard University Press.

Polanyi, Karl. 1944. The Great Transformation. New York, Toronto: Farrar \& Rinehart.

Pomeranz, Kenneth. 2000. The Great Divergence: China, Europe, and the Making of the Modern World Economy. Princeton, N.J.: Princeton University Press.

QI, Xia 漆侠. 1999. Zhongguo jingji tongshi Songdai jingjijuan [中国经济通史. 宋代经济卷 General Economic History of China: Song Dynasty]. Beijing: Jingji ribao chubanshe.

QI, Xia 漆侠. 2009. Songdai jingjishi [宋代经济卷史 Economic history of Song]. Beijing: Zhonghua shuju.

QIAN Mu (钱穆). 1966. 中国历代政治得失 Zhongguo lidai zhengzhi deshi [The Gains and Losses of Chinese Dynastic Politics]. Hong Kong : 大中国印刷厂。

Qian, Yingyi. 2000. “The Process of China's Market Transition (1978-1998): The Evolutionary, Historical, and Comparative Perspectives." Journal of Institutional and Theoretical Economics 156.1: pp. 151-171.

Qian, Yingyi and Jinglian Wu. 2003. "China's Transition to a Market Economy: How Far Across the River?" In Nicholas C. Hope, Dennis Tao Yang and Mu Yang Li eds., How Far Across the River? Chinese Policy Reform at the Millennium. Stanford: Stanford University Press.

Ravallion, Martin and Shaohua Chen. 2007. "China's (Uneven) Progress against Poverty." Journal of Development Economics, 82:1, pp. 1-42.

Rawski, Evelyn Sakakida. 1972. Agricultural Change and the Peasant Economy of South China. Cambridge: Harvard University Press.

Rawski, Evelyn Sakakida. 1979. Education and Popular Literacy in Ch'ing China. Ann Arbor: University of Michigan Press.

Rawski, Thomas G. 1969. "Chinese Dominance of Treaty Port Commerce and its Implications, 1860-1875." Explorations in Economic History, 7: 1-2, pp. 451-473.

Rawski, Thomas G. 1975. "The Growth of Producer Industries, 1900-1971, " in Dwight H. Perkins, ed., China's Modern Economy in Historical Perspective. Stanford: Stanford University Press, pp. 203-234.

Rawski, Thomas G. 1980. China's Transition to Industrialism: Producer Goods and Economic Development in the Twentieth Century. Ann Arbor: University of Michigan Press. 
Rawski, Thomas G. 1982. " The Simple Arithmetic of Income Distribution in China." Keizai Kenkyū [Economic Research], 33:1, pp. 12-26.

Rawski, Thomas G. 1989. Economic Growth in Prewar China. Berkeley: University of California Press.

Rawski, Thomas G. 2002. "Will Investment Behavior Constrain China's Growth?" China Economic Review 13.4: 361-372.

Rawski, Thomas G. 2006. "Recent Developments in China's Labor Economy." In Katsuji Nakagane and Tomoyiku Kojima eds., Restructuring China: Party, State and Society After the Reform and Open Door. Tokyo: The Toyo Bunko.

Rawski, Thomas G. 2007. "Social Capabilities and Chinese Economic Growth," in Social change in contemporary China: C.K. Yang and the Concept of Institutional Diffusion. Wenfang Tang and Burkart Holzner eds. Pittsburgh PA: University of Pittsburgh Press, pp. 89-103.

Rawski, Thomas G. 2011a. "Human Resources and China's Long Economic Boom," Asia Policy no. 12 (July): 33-78.

Rawski, Thomas G. 2011 b. "Is China's Development Success Transferable?" In Reform and Development in China. In Ho-Mou Wu and Yang Yao eds. London and New York: Routledge, pp. 320-348.

Rawski, Thomas G. and Robert W. Mead. 1998. "On the Trail of China's Phantom Farmers." World Development, 26:5, pp. 7

Remer, Charles F. 1933. Foreign Investments in China. New York: The Macmillan Company.

Reynolds, Douglas R. 1993. China, 1898-1912: the Xinzheng Revolution and Japan. Cambridge MA: Harvard University Council on East Asian Studies.

Richards, John F. 2003. The Unending Frontier: An Environmental History of the Early Modern World. Berkeley: University of California Press.

Riskin, Carl. 1987. China's Political Economy: the Quest for Development Since 1949. Oxford [Oxfordshire]; New York: Oxford University Press.

Roll, Charles R. 1980. The Distribution of Rural Incomes in China: A Comparison of the 1930s and the 1950s. New York: Garland.

Romer, Paul. 1993. "Idea Gaps and Object Gaps in Economic Development. " Journal of Monetary Economics, 32, pp. 543-73.

Rosenthal, Jean-Laurent and R. Bin Wong. 2011. Before and Beyond Divergence : the Politics of Economic Change in China and Europe. Cambridge MA: Harvard University Press.

Rowe, William T. 1984. Hankow: Commerce and Society in a Chinese City, 1796-1889. Stanford: Stanford University Press.

Rowe, William T. 1992. "Ming-Qing Guilds." Ming Qing yanjiu. September, pp. 47-60. 
Roy, Tirthankar. 2012. "Consumption of Cotton Cloth in India, 1795-1940." Australian Economic History Review 52 (1). pp. 61-84.

Rozman, Gilbert. 1974. Urban Networks in Ch'ing China and Tokugawa Japan. Princeton, N.J.: Princeton University Press.

SAITŌ, Osamu, 2002. "Dentō Chūgoku no rekishi jinkōgaku [Historical Demography of Traditional China]. Shakai keizai shigaku [Research in Socio-economic History] 68.2: 87100.

Schleifer, Andrei and Robert W. Vishny. 1998. The Grabbing Hand: Government Pathologies and Their Cures. Cambridge MA: Harvard University Press.

Schran, Peter. 1969. The Development of Chinese Agriculture, 1950-1959. Urbana: University of Illinois Press.

Schran, Peter. 1976. Guerrilla Economy: the Development of the Shensi-Kansu-Ninghsia Border Region, 1937-1945. Albany: State University of New York Press.

Schran, Peter. 1978. "China's Demographic Evolution 1850-1953 Reconsidered." China Quarterly: 75, pp. 639-46.

Schumpeter, Elizabeth B. 1940. The Industrialization of Japan and Manchukuo, 1930-1940: Population, Raw Materials and Industry. New York: Macmillan.

SHIGA Shuzo, TERADA Hiroaki, KISHIMOTO Mio, and FUMA Susumu. 1998. Ming Qing shiqi de minshi shenpan yu minjian qiyue [Civil Trials and Civil Contracts in Ming and Qing China], edited by WANG Yaxin and LIANG Zhiping. Beijing: Law Press.

Shirk, Susan L. 1993. The Political Logic of Economic Reform in China. Berkeley: University of California Press.

Shiroyama, Tomoko. 2008. China during the Great Depression: Market, State, and the World Economy, 1929-1937. Cambridge MA: Harvard University Asia Center.

Shiue, Carol H. and Wolfgang Keller. 2007. "Markets in China and Europe on the Eve of the Industrial Revolution." American Economic Review, 97:4, pp. 1189-216.

Skinner, G. William. 1957. Chinese Society in Thailand. Ithaca: Cornell University Press.

Skinner, G. William. 1964. Marketing and Social Structure in Rural China. Ann Arbor: Association for Asian Studies.

Skinner, G. William. 1977a. "Cities and the Hierarchy of Local Systems," in The City in Late Imperial China. G. William Skinner ed. Stanford: Stanford University Press, pp. 275-351.

Skinner, G. William. 1977b. "Introduction: Urban Development in Imperial China," in The City in Late Imperial China. G. William Skinner ed. Stanford: Stanford University Press, pp. 132. 
Skinner, G. William. 1977c. "Regional Urbanization in Nineteenth-Century China," in The City in Late Imperial China. G. William Skinner ed. Stanford, Calif.: Stanford University Press, pp. 211-49.

Skinner, G. William. 1987. "Sichuan's Population in the Nineteenth Century: Lessons from Disaggregated Data." Late Imperial China, 8:1, pp. 1-79.

Smith, Thomas C. 1959. The Agrarian Origins of Modern Japan. Stanford, Calif.: Stanford University Press.

Smith, Thomas C. 1988. Native Sources of Japanese Industrialization, 1750-1920. Berkeley, Calif.: University of California Press.

Sng, Tuan-hwee. 2010. "Size and Dynastic Decline: The Principal-Agent Problem in Late Imperial China 1700-1850." Department of Economics, Northwestern University: Evanston IL.

So, Billy K.L. and Ramon H. Myers, eds. 2011. The Treaty Port Economy in Modern China. Berkeley: Institute of East Asian Studies. China Research Monograph 65

Sommer, Matthew H. 2010. "Abortion in Late Imperial China: Routine Birth Control or Crisis Intervention?" Late Imperial China, 31:2, pp. 97-165.

Steinfeld, Edward. 1998. Forging reform in China: the Fate of State-owned Industry.

Cambridge and New York. Cambridge University Press.

Strauss, Julia C. 1997. "The Evolution of Republican Government." The China Quarterly, No. 150, pp. 329-351.

Strauss, Julia C. 1998. Strong institutions in weak polities: state building in Republican China, 19271940. Oxford: Clarendon Press.

SU, Yegong. 2000. Ming Qing lüdian yu tianli [Ming Qing Legal Codes and Statures]. Beijing: China Law University Press.

SUDŌ Yoshiyuki. 1962. Sōdai keizaishi kenkyū [Studies on Song dynasty economic history]. Tokyo: Tōkyō daigaku shuppankai.

Sun, E-Tu Zen. 1986 "The growth of the academic community 1912-1949." In John K. Fairbank and Albert Feuerwerker eds., The Cambridge History of China Vol. 13: Republican China 19121949, Part 2, Chapter 8. Cambridge: Cambridge University Press.

SUZUKI, Tomō. 1992. Yōmu undō no kenkyū: Jukyuseiki kohan no Chūgoku ni okeru kōgyōka [The Self-Strengthening Movement: Industrialization in late $19^{\text {th }}$-century China]. Tokyō: Kyūko Shoin.

Tao, Jing-shen. 2009. "The Move to the South and the Reign of Kao-Tsung (1127-1162)," in The Cambridge History of China: The Sung Dynasty and its Precursors, 907-1279. Denis Crispin Twitchett and Paul Jacov Smith eds. Cambridge [Eng.] ; New York: Cambridge University Press, pp. 644-709. 
Tawney, R. H. 1932. Land and Labour in China. New York: Harcourt, Brace.

Te Velde, Dirk Willem. 2006. "Foreign Investment and Development: An Historical Perspective." Background paper for the "World Economic and Social Survey for 2006." Available at http://www.odi.org.uk/resources/docs/850.pdf.

Telford, Ted A. 1990. "Patching the Holes in Chinese Genealogies: Mortality in the Lineage Populations of Tongcheng County, 1300-1880. " Late Imperial China, 11.2, pp. 116-36.

Tirole, Jean. 1986. "Hierarchies and Bureaucracies: On the Role of Collusion in Organizations." Journal of Law, Economics, \& Organization, 2:2, pp. 181-214.

Tsai, Kellee S. 2002. Back-Alley Banking: Private Entrepreneurs in China. Ithaca, N.Y.: Cornell University Press.

Tu, Wei-ming, Ed. 1996. Confucian Tradtions in East Asian Modernity: Moral Education and Economic Culture in Japan and the Four Mini-Dragons. Cambridge MA: Harvard University Press.

Twomey, Michael J. 2000. A Century of Foreign Investment in the Third World. Florence KY: Routledge.

Van Zanden, Jan Luiten. 2009., The Long Road to the Industrial Revolution: the European Economy in a Global Perspective, 1000-1800. Leiden: Brill.

Viraphol, Sarasin. 1977. Tribute and Profit: Sino-Siamese Trade, 1652-1853. Cambridge, Mass.: Council on East Asian Studies Harvard University: distributed by Harvard University Press.

Von Glahn, Richard. 1996. Fountain of Fortune: Money and Monetary Policy in China, 10001700. Berkeley: University of California Press.

Von Glahn, Richard. 2003. "Money Use in China and Changing Patterns of Global Trade in Monetary Metals, 1500-1800." In Global Connections and Monetary History, 1470-1800, ed. Dennis O. Flynn, Auturo Giraldez, and Richard von Glahn, Burlington VT: Ashgate.

Von Glahn, Richard. 2004. "Revisiting the Song Monetary Revolution: A Review Essay." International Journal of Asian Studies, 1:1, pp. 159-78.

Wagner, Donald B. 2001. "The Administration of the Iron Industry in Eleventh-Century China," Journal of the Economic and Social History of the Orient, 44(2), pp. 175 - 197.

Wagner, Donald B. 2008. Science and Civilisation in China, Vol. 5: Chemistry and Chemical Technology, Part 11: Ferrous Metallurgy. Cambridge: Cambridge University Press

Wang, Dong. 2005. China's Unequal Treaties: Narrating National History. Lanham MD: Lexington Books.

WANG, Ya'nan. 1981/2005. (王亚南). 中国官僚政治研究 Zhongguo guanliao zhengzhi yanjiu [The Politics of Chinese Bureaucracy]. Beijing: Zhongguo shehui kexue chubanshe. 
Wang, Yeh-chien. 1973. Land Taxation in Imperial China, 1750-1911. Cambridge, Mass.: Harvard University Press.

Wang, Yeh-chien. 1990. Review of Kang Chao, Man and Land in Chinese History. Harvard Journal of Asiatic Studies 50.1, pp. 407-411.

Wang, Yeh-chien. 1992. "Secular Trends of Rice Prices in the Yangzi Delta, 1638-1935," in Chinese History in Economic Perspective. Thomas G. Rawski and Lillian M. Li eds. Berkeley: University of California Press, pp. 35-68.

Whiting, Susan H. 2001. Power and Wealth in Rural China: the Political Economy of Institutional Change. Cambridge; New York: Cambridge University Press.

Whitney, Joseph B. R. 1970. China: Area, Administration, and Nation Building. [Chicago]: University of Chicago, Dept. of Geography.

Wilkinson, Endymion Porter. 1998. Chinese History: a Manual. Cambridge, Mass.: Harvard University Asia Center.

Will, Pierre-Etienne, Roy Bin Wong, and James Z. Lee. 1991. Nourish the People: The State Civilian Granary System in China, 1650-1850. Ann Arbor: Center for Chinese Studies, University of Michigan.

Williamson, Jeffrey G. 2011. Trade and Poverty: When the Third World Fell Behind. Cambridge MA: MIT Press.

Wittfogel, Karl A. 1957/1976. Oriental Despotism: a Comparative Study of Total Power. New Haven: Yale University Press.

Wong, Christine. 1985. "Material Allocation and Decentralization: Impact of the Local Sector on Industrial Reform," in The Political Economy of Reform in Post-Mao China. Elizabeth J. Perry and Christine Wong eds. Cambridge, Mass.: Council on East Asian Studies/Harvard University, pp. 253-78.

Wong, Christine, and Richard M. Bird. 2008. "China's Fiscal System: A Work in Progress," in China's Great Economic Transformation. Loren Brandt and Thomas G. Rawski eds. Cambridge and New York: Cambridge University Press, pp. 429-466.

Wong, John. 1973. Land Reform in the People's Republic of China; Institutional Transformation in Agriculture. New York: Praeger Publishers.

Wong, Roy Bin. 1997. China Transformed: Historical Change and the Limits of European Experience. Ithaca: Cornell University Press.

World Bank 2012. The World Bank and Development Research Center of the State Council, the People's Republic of China. China 2030: Building a Modern, Harmonious, and Creative High-Income Society. http://www.worldbank.org/content/dam/Worldbank/document/China-2030complete.pdf . accessed 18 December 2012. 
Wright, Mary C. 1962. The Last Stand of Chinese Conservatism: the T'ung-chih Restoration, 1862-1874. Stanford: Stanford University Press.

Wright, Tim. 1984. Coal Mining in China's Economy and Society, 1895-1937. Cambridge ; New York: Cambridge University Press.

WU Chengming. 2002. Wu Chengming ji [Collected Works of Wu Chengming]. Beijing: Zhongguo shehui kexue chubanshe.

XIONG, Yuzhi. 2011，西学东渐与晚清社会 (The Eastward Diffusion of Western Studies in Late Qing). Beijing: China People's University Press.

Xu, Chenggang. 2011. "The Fundamental Institutions of China's Reforms and Development." Journal of Economic Literature 49.4, pp. 1076-1151.

XU, Dixin and WU Chengming Eds. 2000. Chinese Capitalism, 1522-1840. English translation by LI Zhengde, LIANG Miaoru and LI Siping. New York: St. Martin's Press.

Xu, Xiaoqun 2001, Chinese Professionals and the Republican State. Cambridge: Cambridge University Press.

Yamamura, Kozo. 1997. The Economic Emergence of Modern Japan. Cambridge, UK ; New York: Cambridge University Press.

YAN, Zhongping et al. 2007. Zhongguo jindai jingjishi, 1840-1894 [The Economic History of Modern China 1840-1894]. 中国近代经济史，1840-1894. Beijing: Jingji guanli chubanshe.

YAN, Zhongping 严中平 et al. 1955. , Zhongguo jindai jingjishi tongji ziliao xuanji. 中国近代经 济史统计资料选辑 [Statistical materials on the Economic History of Modern China]. Beijing: Kexue chubanshe.

Yearbook. Zhongguo tongji nianjian [China Statistics Yearbook]. Annual. Beijing: Zhongguo tongji chubanshe.

Yi, Gang. 2010. "The Intrinsic Logic of China's Banking Reform." In Fang Cai ed., Transforming the Chinese Economy. Leiden and Boston: Brill, pp. 115-148.

Yuan, Weiping and Debin Ma 2010. "Merchant Account Books and Economic History Research, the case of Tongtai Sheng Business Accounts" (in Chinese). Zhongguo jingjishi yanjiu [Research on Chinese Economic History (中国经济史研究)]. Vol. 2, 2010.

Yuchtman, Noam. 2010. "Teaching to the Tests: An Economic Analysis of Traditional and Modern Education in Late Imperial and Republican China. Working paper.

Yusuf, Shahid, Kaoru Nabeshima and Dwight H. Perkins 2006. Under New Ownership: Privatizing China's State-Owned Enterprises. Palo Alto: Stanford University Press.

Zelin, Madeleine. 1984. The Magistrate's Tael: Rationalizing Fiscal Reform in Eighteenth-Century Ch'ing China. Berkeley: University of California Press. 
Zelin, Madeleine. 1991. "The Structure of the Chinese Economy during the Qing Period: Some Thoughts on the 150th Anniversary of the Opium War, " in Perspectives on Modern

China: Four Anniversaries. Kenneth Lieberthal et al eds. Armonk: M.E. Sharpe, pp. 31-67.

Zelin, Madeleine. 1994. "Merchant Dispute Mediation in Twentieth Century Zigong,

Sichuan." In Civil Law in Qing and Republican China, ed. Kathryn Bernhardt and Philip

C.C. Huang. Stanford: Stanford University Press, pp. 249-286.

Zelin, Madeleine. 2009. "The Firm in Early Modern China." Journal of Economic Behavior \& Organization 71: 623-637

Zhang, David D., Jane Zhang, Harry F. Lee, Yuan-qing He, "Climate Change and War Frequency in Eastern China over the Last Millennium." Human Ecology, Vol. 35, No. 4, pp. 403-414.

ZHANG Deyi, HAO Yisheng, SUN Jinzhu, and PAN Xiaobai. Zhongguo lidai tudi qizheng [Chinese Historical Land Records]. Baoding: Hebeidaxue chubanshe, 2009.

ZHAO Jin, 1994. 中国城市房地产史论1840-1949 (On the History of Chinese Urban Real Estate 1840-1949), Tianjin: Nankai University Press.

ZHAO, Ziyang. 2009. Prisoner of the State: the Secret Journal of Zhao Ziyang. Translated and edited by Bao Pu, Renee Chiang, and Adi Ignatius. New York: Simon \& Schuster.

ZHOU Zhenghe. 2009. Xxx 体国经野之道: 中国行政区划沿革 ([A History of the Evolution of Chinese Administrative Organization]). Shanghai: Shanghai Century Publishers.

ZHOU, Yumin. 2000. Wan Qing caizheng yu shehui bianqian 晚清财政与社会变迁 [Late Qing Public Finance and Social Transformation]. Shanghai: Shanghai renmin chubanshe.

Zurndorfer, Harriet Thelma. 1989. Change and Continuity in Chinese Local History: The Development of Huizhou Prefecture, 800 to 1800. Leiden ; New York: E.J. Brill. 
Map 1. Chinese Territory under Ming (shaded) and Qing

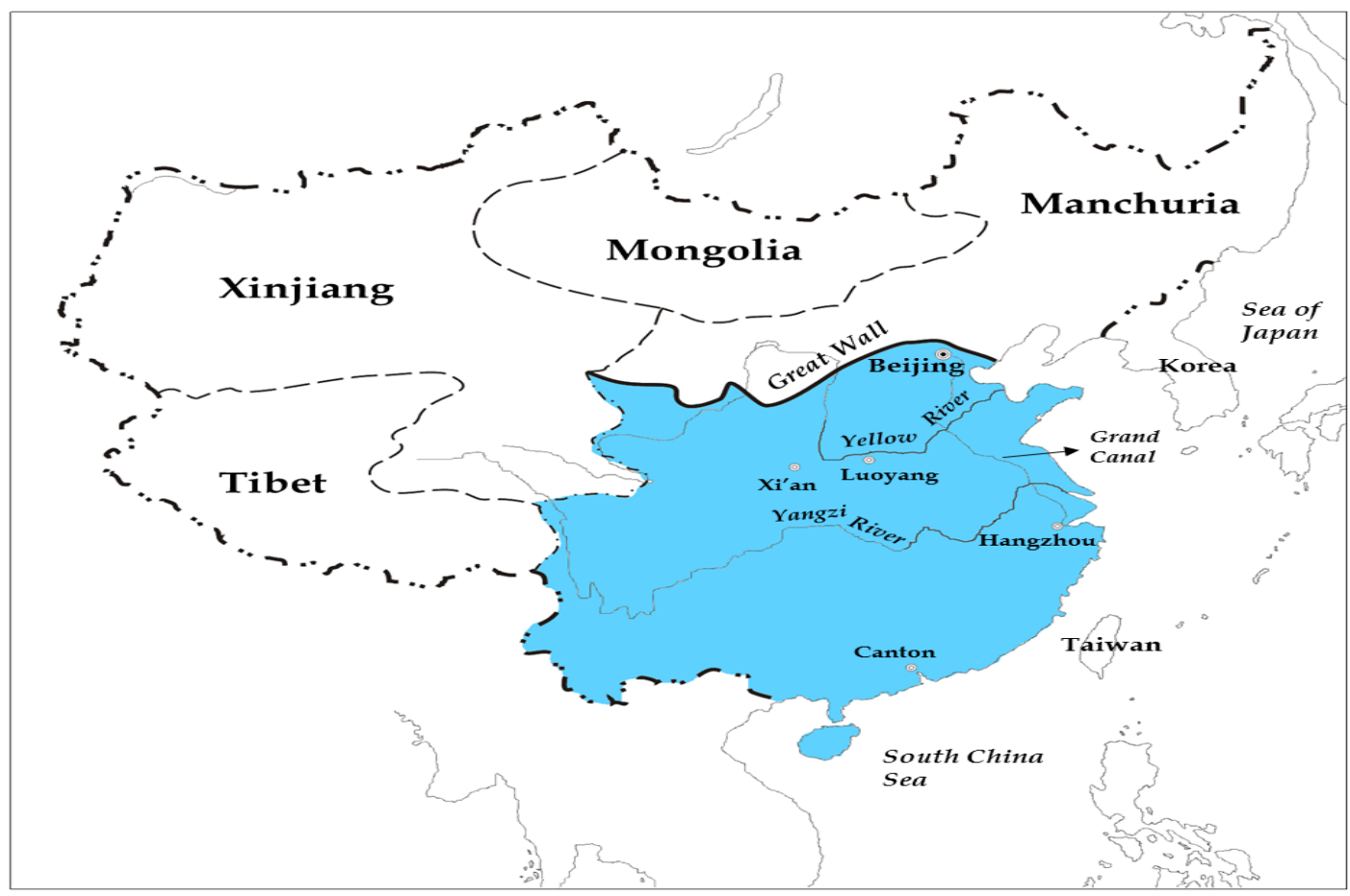




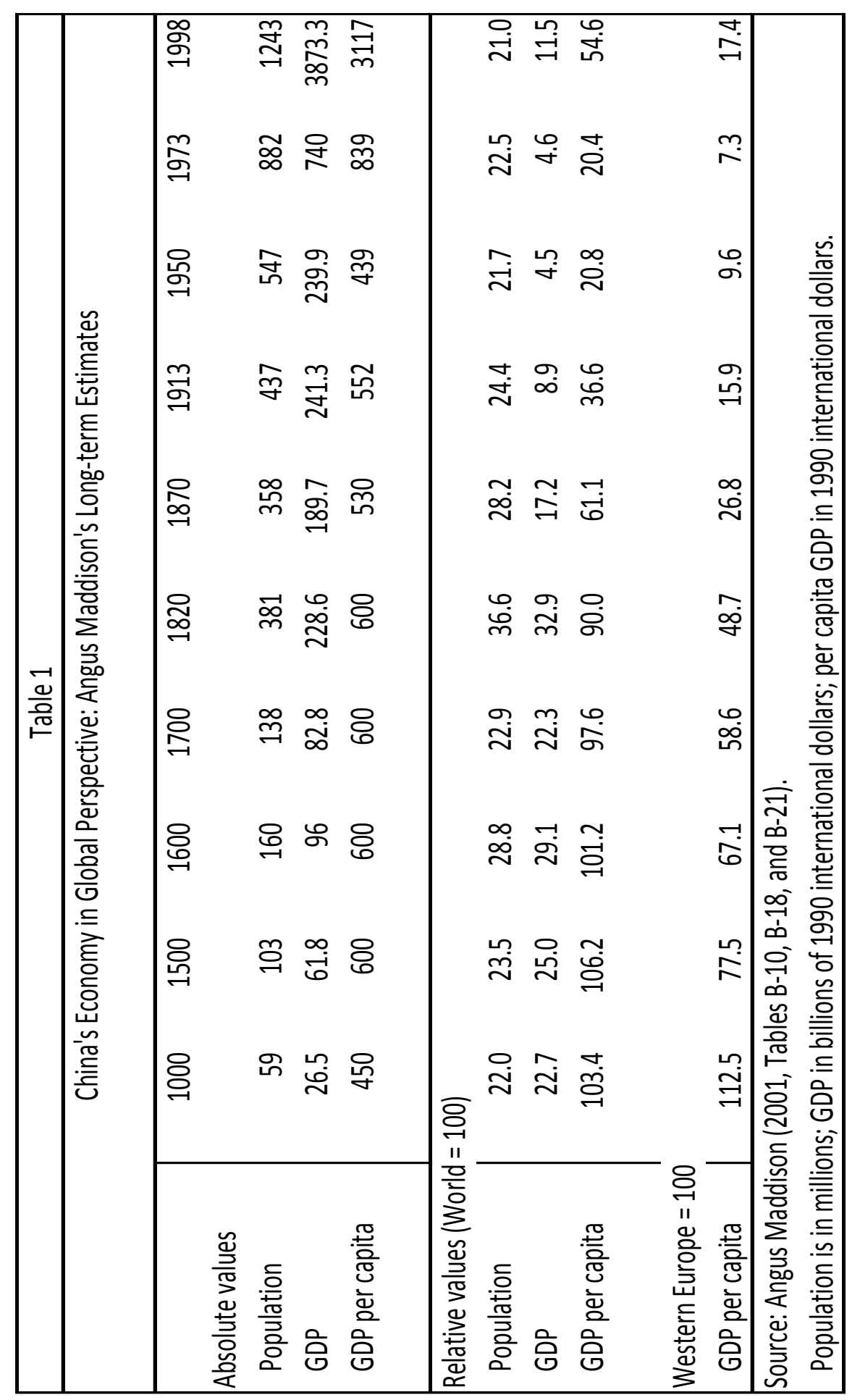

Note: An extensive discussion by Ch'üan and Kraus (1975, pp. 79-98) concludes that "the likely weight of an imperial shih (shi) of milled rice in the eighteenth century was about 185 pounds" (p. 98). 
Table 2: Tax Revenues in China, 1085-1776 (in shi of rice)

\begin{tabular}{|l|c|c|c|c|c|}
\hline & $\begin{array}{c}\text { Per capita } \\
\text { land tax }\end{array}$ & $\begin{array}{c}\text { Per capita } \\
\text { indirect } \\
\text { taxes }\end{array}$ & Total taxes & $\begin{array}{c}\text { Per capita } \\
\text { tax burden }\end{array}$ & $\begin{array}{c}\text { Index } \\
(1085=100)\end{array}$ \\
\hline Song (1085) & 0.26 & 0.54 & $72,102,000$ & 0.8 & 100 \\
\hline Ming (1407) & $0.54-0.76$ & $0.02-0.03$ & $47,657,000$ & $0.56-0.79$ & $70-98$ \\
\hline Ming (1577) & 0.21 & 0.03 & $42,185,000$ & 0.24 & 30 \\
\hline Qing (1685) & 0.18 & 0.04 & $38,044,444$ & 0.24 & 30 \\
\hline Qing (1776) & 0.09 & 0.03 & $36,620,000$ & 0.12 & 15 \\
\hline
\end{tabular}

Source: data compiled by Professor Guanglin Liu

Note: An extensive discussion by Ch'üan and Kraus (1975, pp. 79-98) concludes that "the likely weight of an imperial shih (shi) of milled rice in the eighteenth century was about 185 pounds" (p. 98). 


\section{Table 3. Qing Central Government Annual Revenue in International Comparison}

\section{A. Aggregate Revenue(tons of silver)}

\begin{tabular}{|cccccccc|}
\hline & China & Ottoman & Russia & France & Spain & England & Dutch R* \\
\hline $1650-99$ & 940 & 248 & & 851 & 243 & 239 & \\
$1700-49$ & 1304 & 294 & 155 & 932 & 312 & 632 & 310 \\
$1750-99$ & 1229 & 263 & 492 & 1612 & 618 & 1370 & 350 \\
$1800-49$ & 1367 & & & & & 6156 & \\
$1850-99$ & 2651 & & & & & 10941 & \\
\hline
\end{tabular}

B. International Comparison of per capita Tax Revenue (grams of silver)

\begin{tabular}{|c|c|c|c|c|c|c|c|}
\hline & China & Ottoman & Russia & France & Spain & England & Dutch $\mathrm{R}^{*}$ \\
\hline 1650-99 & 7.0 & 11.8 & & 46.0 & 35.8 & 45.1 & \\
\hline $1700-49$ & 7.2 & 15.5 & 6.4 & 46.6 & 41.6 & 93.5 & 161.1 \\
\hline 1750-99 & 4.2 & 12.9 & 21 & 66.4 & 63.1 & 158.4 & 170.7 \\
\hline $1800-49$ & 3.4 & & & & & 303.8 & \\
\hline $1850-99$ & 7.0 & & & & & 344.1 & \\
\hline & China & Ottoman & Russia & France & Spain & England & Dutch $\mathrm{R}^{*}$ \\
\hline 1650-99 & & 1.7 & & 8.0 & 7.7 & 4.2 & 13.6 \\
\hline $1700-49$ & 2.26 & 2.6 & 6.4 & 6.7 & 4.6 & 8.9 & 24.1 \\
\hline 1750-99 & 1.32 & 2.0 & 8.3 & 11.4 & 10.0 & 12.6 & 22.8 \\
\hline $1800-49$ & 1.23 & & & & & 17.2 & \\
\hline 1850-99 & 1.99 & & & & & 19.4 & \\
\hline
\end{tabular}

Source: see Debin Ma 2011a, with thanks to Kivanc Karaman, Sevket Pamuk, Peter Lindert and Steve Nafziger for sharing datasets.

*Dutch Republic

Conversion notes: one Chinese silver tael $=37$ grams of silver.

For per capita revenue in days of urban unskilled wages, 1650-59, 1700-09 figures are used to represent 1650-99, 1700-49 respectively. Average of 1750-50 and 1780-89 are used to represent 1750-99 for all other countries except China. See http://:www.ata.boun.edu.tr/sevketpamuk/JEH2010articledatabase. Nominal wages for China and England are for Beijing and London drawn from Robert C. Allen et al 2010. 


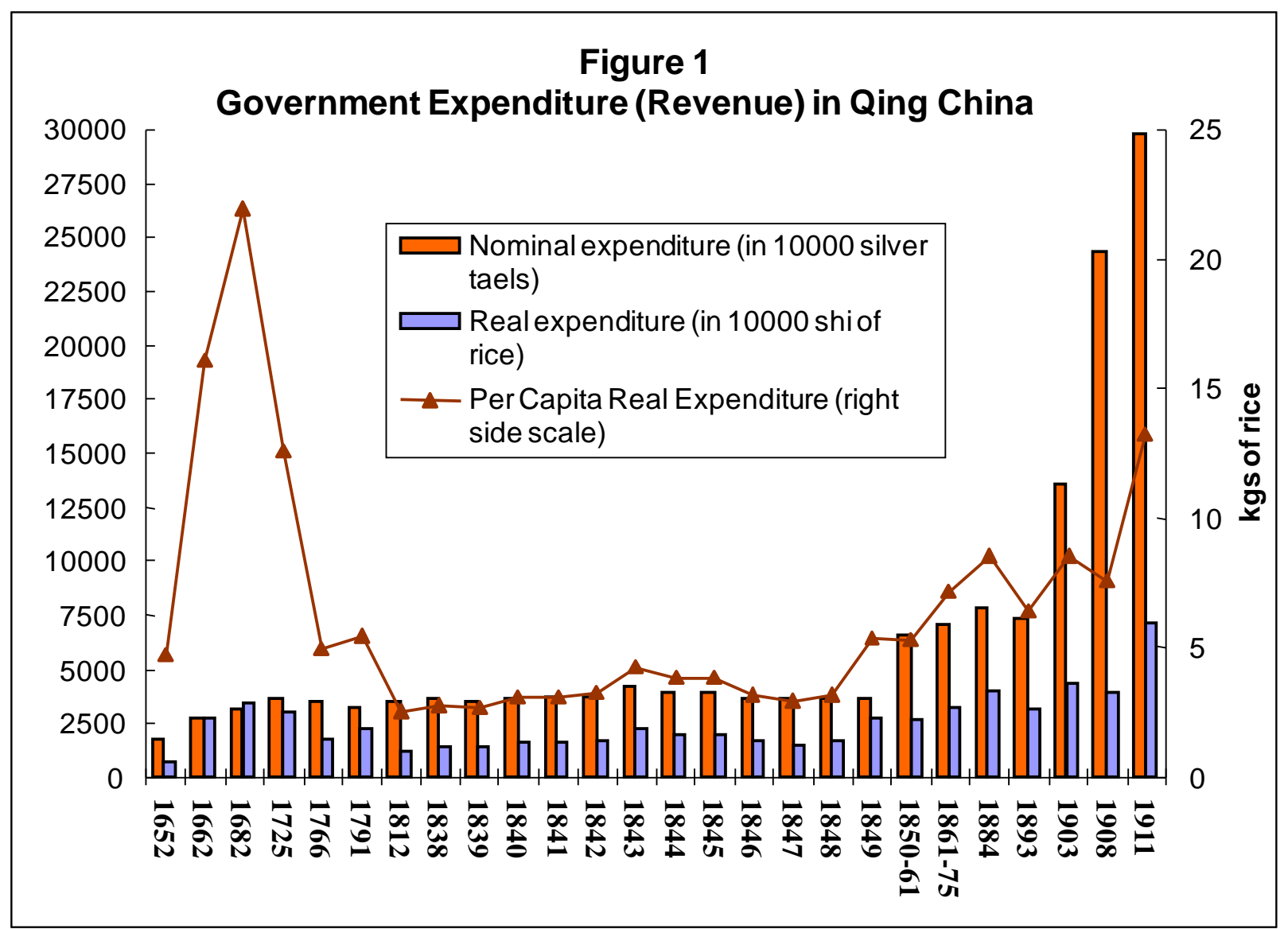

Sources: fiscal data are from IWAI Shegeki (2004, p. 37) and HAMASHITA Takeshi (2006, p. 73); population from Angus Maddison (2007); grain prices are from Yeh-chien Wang (1992). 


\section{LONDON SCHOOL OF ECONOMICS}

\section{ECONOMIC HISTORY DEPARTMENT WORKING PAPERS}

(from 2009 onwards) For a full list of titles visit our webpage at

http://www.lse.ac.uk/

2009

WP114 War and Wealth: Economic Opportunity Before and After the Civil War, 1850-1870

Taylor Jaworski

WP115 Business Cycles and Economic Policy, 1914-1945: A Survey Albrecht Ritschl and Tobias Straumann

WP116 The Impact of School Provision on Pupil Attendance: Evidence From the Early $20^{\text {th }}$ Century Mary MacKinnon and Chris Minns

WP117 Why Easter Island Collapsed: An Answer for an Enduring Question Barzin Pakandam

WP118 Rules and Reality: Quantifying the Practice of Apprenticeship in Early Modern Europe

Chris Minns and Patrick Wallis

WP119 Time and Productivity Growth in Services: How Motion Pictures Industrialized Entertainment Gerben Bakker

WP120 The Pattern of Trade in Seventeenth-Century Mughal India: Towards An Economic Explanation Jagjeet Lally

WP121 Bairoch Revisited. Tariff Structure and Growth in the Late $19^{\text {th }}$ Century Antonio Tena-Junguito

WP122 Evolution of Living Standards and Human Capital in China in 18-20 Centuries: Evidences from Real Wage and Anthropometrics Joerg Baten, Debin Ma, Stephen Morgan and Qing Wang

WP123 Wages, Prices, and Living Standards in China, 1738-1925: in Comparison with Europe, Japan, and India 
Robert C. Allen, Jean-Pascal Bassino, Debin Ma, Christine Moll-Murata, Jan Luiten van Zanden

WP124 Law and Economic Change in Traditional China: A Comparative Perspective Debin Ma

WP125 Leaving Home and Entering Service: The Age of Apprenticeship in Early Modern London

Patrick Wallis, Cliff Webb and Chris Minns

WP126 After the Great Debasement, 1544-51: Did Gresham's Law Apply? Ling-Fan $\mathrm{Li}$

WP127 Did Globalization Aid Industrial Development in Colonial India? A Study of Knowledge Transfer in the Iron Industry

Tirthankar Roy

WP128 The Education and Training of Gentry Sons in Early-Modern England Patrick Wallis and Cliff Webb

WP129 Does Trade Explain Europe's Rise? Geography, Market Size and Economic Development Roman Studer

WP130 Depression Econometrics: A FAVAR Model of Monetary Policy During the Great Depression

Pooyan Amir Ahmadi and Albrecht Ritschl

WP131 The Economic Legacies of the 'Thin White Line': Indirect Rule and the Comparative Development of Sub-Saharan Africa Peter Richens

WP132 Money, States and Empire: Financial Integration Cycles and Institutional Change in Central Europe, 1400-1520 David Chilosi and Oliver Volckart

WP133 Regional Market Integration in Italy During the Unification (1832-1882) Anna Missiaia

\section{0}

WP134 Total Factor Productivity for the Royal Navy from Victory at Texal (1653) to Triumph at Trafalgar (1805)

Patrick Karl O'Brien FBA and Xavier Duran 
WP135 From Sickness to Death: The Financial Viability of the English Friendly Societies and Coming of the Old Age Pensions Act, 1875-1908 Nicholas Broten

WP136 Pirates, Polities and Companies: Global Politics on the Konkan Littoral, c. $1690-1756$

Derek L. Elliott

WP137 Were British Railway Companies Well-Managed in the Early Twentieth Century?

Nicholas Crafts, Timothy Leunig and Abay Mulatu

WP138 Merchant Networks, the Baltic and the Expansion of European LongDistance Trade: Re-evaluating the Role of Voluntary Organisations Esther Sahle

WP139 The Amazing Synchronicity of the Global Development (the 1300s1450s). An Institutional Approach to the Globalization of the Late Middle Ages

Lucy Badalian and Victor Krivorotov

WP140 Good or Bad Money? Debasement, Society and the State in the Late Middle Ages

David Chilosi and Oliver Volckart

WP141 Becoming a London Goldsmith in the Seventeenth Century: Social Capital and Mobility of Apprentices and Masters of the Guild Raphaelle Schwarzberg

WP142 Rethinking the Origins of British India: State Formation and MilitaryFiscal Undertakings in an Eighteenth Century World Region Tirthankar Roy

WP143 Exotic Drugs and English Medicine: England's Drug Trade, c.1550C. 1800

Patrick Wallis

WP144 Books or Bullion? Printing, Mining and Financial Integration in Central Europe from the 1460s

David Chilosi and Oliver Volckart

WP145 'Deep' Integration of $19^{\text {th }}$ Century Grain Markets: Coordination and Standardisation in a Global Value Chain Aashish Velkar 
WP146 The Utility of a Common Coinage: Currency Unions and the Integration of Money Markets in Late Medieval Central Europe Lars Boerner and Oliver Volckart

WP147 The Cost of Living in London, 1740-1837 Ralph Turvey

WP148 Labour Market Dynamics in Canada, 1891-1911: A First Look From New Census Samples

Kris Inwood, Mary MacKinnon and Chris Minns

WP149 Economic Effects of Vertical Disintegration: The American Motion Picture Industry, 1945 to 1955

Gregory Mead Silver

2011

WP150 The Contributions of Warfare with Revolutionary and Napoleonic France to the Consolidation and Progress of the British Industrial Revolution Patrick Karl O'Brien

WP151 From a "Normal Recession" to the "Great Depression": Finding the Turning Point in Chicago Bank Portfolios, 1923-1933 Natacha Postel-Vinay

WP152 Rock, Scissors, Paper: the Problem of Incentives and Information in Traditional Chinese State and the Origin of Great Divergence Debin Ma

WP153 The Finances of the East India Company in India, C.1766-1859 John F. Richards

WP154 Labour, law and training in early modern London: apprenticeship and the city's institutions Patrick Wallis

WP155 Why did (pre-industrial) firms train? Premiums and apprenticeship contracts in $18^{\text {th }}$ century England

Chris Minns, Patrick Wallis 
WP156 Merchantilist institutions for a first but precocious industrial revolution; The Bank of England, the Treasury and the money supply, 1694-1797 Patrick O'Brien

2012

WP157 Hand Looms, Power Looms, and Changing Production Organizations: The Case of the Kiryu Weaving District in the Early 20th Century Japan Tomoko Hashino, Keijuro Otsuka

WP158 From Divergence to Convergence: Re-evaluating the History Behind China's Economic Boom Loren Brandt, Debin Ma, Thomas G. Rawski

WP159 Money and Monetary System in China in the $19^{\text {th }}-20^{\text {th }}$ Century: An Overview Debin Ma

WP160 Contesting the Indigenous Development of "Chinese Double-entry Bookkeeping " and its Significance in China's Economic Institutions and Business Organization before c. 1850

Keith Hoskin, Richard Macve

WP161 Steel, Style and Status: The Economics of the Cantilever Chair, 19291936

Tobias Vogelgsang

WP162 The Seven Mechanisms for Achieving Sovereign Debt Sustainability Garrick Hileman

WP163 Reparations, Deficits, and Debt Default: The Great Depression in Germany

Albrecht Ritschl

WP164 Bounded Leviathan: or why North and Weingast are only right on the right half

Alejandra Irigoin, Regina Grafe

WP165 Monetary sovereignty during the classical gold standard era: the Ottoman Empire and Europe, 1880-1913 Coşkun Tunçer

WP166 Going Beyond Social Savings. How would the British economy have developed in the absence of the railways? A case study of Brunner 
Mond 1882-1914.

Edward Longinotti

WP167 Public Finance in Britain and China in the long Eighteenth Century Peer Vries

WP168 The rise of the patent department: A case study of Westinghouse Electric and Manufacturing Company

Shigehiro Nishimura

WP169 The Maghribi industrialists contract enforcement in the Moroccan industry, 1956-82

Romain Ferrali

WP170 Adopting the rights-based model: music multinationals and local music industries since 1945

Gerben Bakker

WP171 The Eighth Wonder of the World: How might access for vehicles have prevented the economic failure of the Thames Tunnel 1843-1865? Rio Lydon

WP 172 Sunk costs and the dynamics of creative industries Gerben Bakker

WP173 A Trojan Horse in Daoguang China? Explaining the flows of silver in and out of China

Alejandra Irigoin

WP174 Evaluating the Swiss Transitory Labour Contribution to Germany in the Second War

Eric Golson 